\title{
12. SOUTHEASTERN ATLANTIC LEG 40 CALCAREOUS NANNOFOSSILS
}

\author{
Franca Proto Decima, Fabio Medizza, and Livio Todesco,
}

Geological Institute, Padua University, Padua, Italy

\section{INTRODUCTION}

This report deals with the study of the calcareous nannofossil content of the six southeastern Atlantic Sites 360 to 365 drilled during DSDP Leg 40 (Figure 1).

Calcareous nannofossils were recovered from all sites; they range in age from Lower Cretaceous (Aptian) to Quaternary and represent an almost complete sequence of the biostratigraphic units for this time interval. All the stratigraphic stages, except for part of the Turonian and the Cenomanian, are represented in the sedimentary record of the investigated sites.

The light microscope was used to examine the 1329 smear slides of the cores sampled. Use of the scanning electron microscope was only made to check the structure of some problematic lower Eocene nannofossils from Site 361 and to illustrate some upper Cretaceous forms.

Of the three authors, F. Proto Decima studied Sites 361, 362, 362A, 363, and 365, F. Medizza Site 364, and L. Todesco Site 360. Discussions and conclusions on biostratigraphic and taxonomic problems were worked out jointly.

Table 1 lists in alphabetical order the nannofossil genera and species considered in this report.

\section{BIOSTRATIGRAPHY}

\section{Cretaceous}

The Lower Cretaceous zonation used in this report is that proposed by Thierstein $(1971,1973)$.

For the subdivision and age determination of the Upper Cretaceous the results of Cepek and Hay (1969), Martini (1969, 1976), Bukry and Bramlette (1970), Manivit (1971), Perch-Nielsen (1972, 1977), and Roth (1973) were considered.

The biostratigraphic distribution of the Cretaceous cores, the events used to fix the boundaries of the zones, and their correlation with the stratigraphic stages and absolute age are summarized in Table 2.

The recognized biozones and their definition are listed as follows in stratigraphic order from older to younger.

\section{Chiastozygus litterarius Zone}

Definition: Interval from the last occurrence of Nannoconus colomii and/or the first occurrence of Chiastozygus litterarius and/or Rucinolithus irregularis to the first occurrence of Parhabdolithus angustus and/or Lithastrinus floralis.

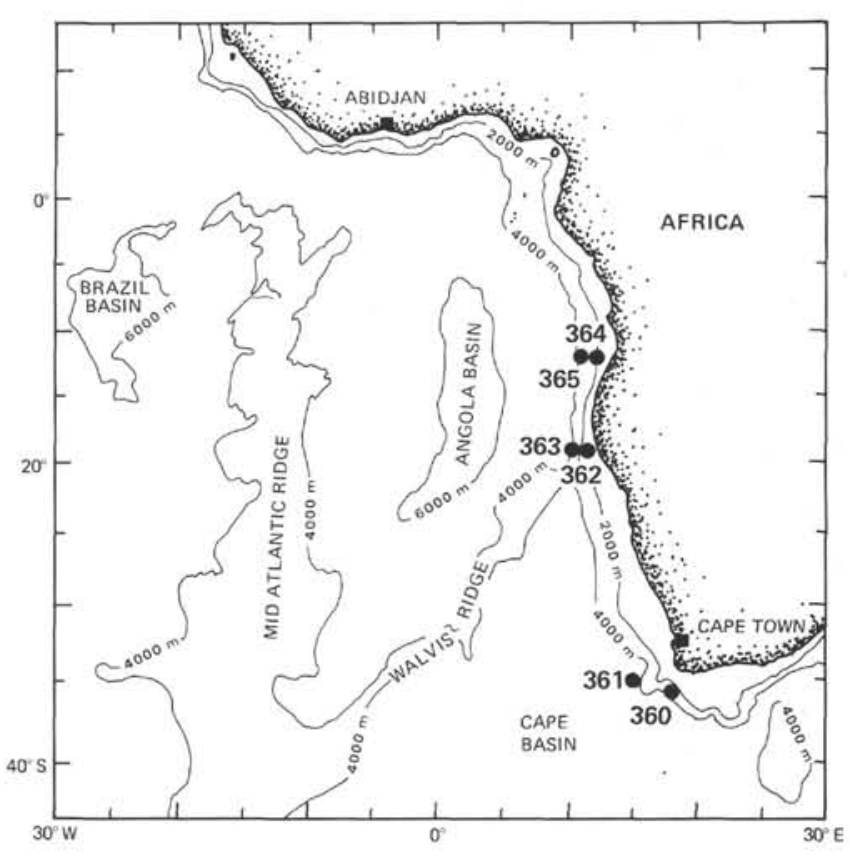

Figure 1. Location of Leg 40 Sites 360-365.

Author: Thierstein (1971, 1973).

Age: Lower Aptian.

The lower boundary of this zone was not recovered on Leg 40 . The poorly preserved nannofossil associations of the lower part of Site 361 were referred to this zone on the concurrence of Micrantholithus hoschulzii, M. obtusus, and Chiastozygus litterarius. They represent the oldest nannofloras recovered in Leg 40.

\section{Parhabdolithus angustus Zone}

Definition: Interval from the first occurrence of Parhabdolithus angustus and/or Lithastrinus floralis, to the first occurrence of Prediscosphaera cretacea.

Author: Manivit (1971), modified Thierstein (1973). Age: Upper Aptian-lower Albian.

\section{Prediscosphaera cretacea Zone}

Definition: Interval from the first occurrence of Prediscosphaera cretacea to the first occurrence of Eiffellithus turriseiffeli.

Author: Thierstein $(1971,1973)$.

Age: Lower Albian to middle Albian.

Eiffellithus turriseiffeli Zone

Definition: Interval from the first occurrence of Eiffellithus turriseiffeli to the first occurrence of Lithraphidites alatus. 
TABLE 1

Selected Nannofossil Species Considered in This Report

\section{CENOZOIC}

Amaurolithus amplificus ( Bukry and Percival, 1971) Gartner and Bukry, 1975 (Plate 5, Figure 8)

Amaurolithus delicatus Gartner and Bukry, 1975 (Plate 5, Figures 3-7)

Amaurolithus primus (Bukry and Bramlette, 1971) Gartner and Bukry, 1975 (Plate 5, Figures 7-11)

Amaurolithus tricorniculatus (Gartner, 1967) Gartner and Bukry, 1975 (Plate 5, Figure 9)

Angulolithina arca Bukry, 1973 (Plate 5, Figure 14)

Aspidorhabdus stylifer (Lohmann, 1902) Boudreaux and Hay, 1969

Blackites spinulus (Levin, 1965) Roth, 1970

Braarudosphaera bigelowii (Gran and Braarud, 1935) Deflandre, 1947

Campylosphaera dela (Bramlette and Sullivan, 1961) Hay and Mohler, 1967 (Plate 10, Figure 3)

Campylosphaera eodela Bukry and Percival, 1971 (Plate 10, Figure 2

Catinaster calyculus Martini and Bramlette, 1963

Catinaster coalitus Martini and Bramlette, 1963

Ceratolithus acutus Gartner and Bukry, 1974 (Plate 4, Figures $5,8,10,11$ )

Ceratolithus cristatus Kamptner, 1954 (Plate 4, Figure 12)

Ceratolithus rugosus Bukry and Bramlette, 1968 (Plate 4, Figures $1-4,6,7,9)$

Chiasmolithus altus Bukry and Percival, 1971

Chiasmolithus bidens (Bramlette and Sullivan, 1961) Hay and Mohler, 1967

Chiasmolithus californicus (Sullivan, 1964) Hay and Mohler, 1967 (Plate 10, Figure 7)

Chiasmolithus consuetus (Bramlette and Sullivan, 1961) Hay and Mohler, 1967

Chiasmolithus danicus (Brotzen, 1959) Hay and Mohler, 1967

Chiasmolithus expansus (Bramlette and Sullivan, 1961) Gartner, 1970

Chiasmolithus gigas (Bramlette and Sullivan, 1961) Radomski, 1968

Chiasmolithus grandis (Bramlette and Riedel, 1954) Radomski, 1968 (Plate 11, Figure 7)

Chiasmolithus oamaruensis (Deflandre, 1954) Hay, Mohler and Wade, 1966

Chiasmolithus solitus (Bramlette and Sullivan, 1961) Locker, 1968

Chiphragmalithus acanthodes Bramlette and Sullivan, 1961

Chiphragmalithus calathus Bramlette and Sullivan, 1961

Coccolithus crassus Bramlette and Sullivan, 1961 (Plate 10, Figure 9)

Coccolithus cribellum (Bramlette and Sullivan, 1961) Stradner, 1962 (Plate 10, Figure 11)

Coccolithus eopelagicus (Bramlette and Riedel, 1954) Bramlette and Sullivan, 1961

Coccolithus magnicrassus Bukry, 1971 (Plate 10, Figure 12)

Coccolithus miopelagicus Bukry, 1971

Coccolithus pelagicus (Wallich, 1877) Schiller, 1930

Coronocyclus nitescens (Kamptner, 1964) Bramlette and Wilcoxon, 1967 (Plate 2, Figure 4)

Cricolithus jonesii Cohen, 1965 (Plate 1, Figures 6, 7)

Cruciplacolithus staurion (Bramlette and Sullivan, 1961) Gartner, 1971

Cruciplacolithus tenuis (Stradner, 1961) Hay and Mohler, 1967 (Plate 10, Figure 1)

Cyclicargolithus abisectus (Müller, 1970) Bukry, 1973 (Plate 2, Figure 5)

Cyclicargolithus floridanus (Roth and Hay, 1967) Bukry, 1971 (Plate 2, Figure 3)

Cyclicargolithus pseudogammation (Bouche, 1962) Bukry, 1973

Cyclicargolithus reticulatus (Gartner and Smith, 1967) n. comb.

Cyclococcolithus formosus Kamptner, 1963

Cyclococcolithus gammation (Bramlette and Sullivan, 1961) Sullivan, 1964

Cyclococcolithus kingii Roth, 1970
TABLE 1 - Continued

Cyclococcolithus leptoporus (Murray and Blackmann, 1898) Kamptner, 1954 (Plate 1, Figure 22)

Cyclococcolithus macintyrei Bukry and Bramlette, 1969 (Plate 2, Figure 6)

Cyclolithella robusta (Bramlette and Sullivan, 1961) Stradner, 1969 (Plate 10, Figure 4)

Dictyococcites bisectus (Hay, Mohler and Wade, 1966) Bukry and Percival, 1971

Dictyococcites scrippsae Bukry and Percival, 1971

Discoaster adamanteus Bramlette and Wilcoxon, 1967

Discoaster asymmetricus Gartner, 1969 (Plate 6, Figure 2; Plate 9, Figure 2)

Discoaster barbadiensis Tan Sin Hok, 1927

Discoaster berggrenii Bukry, 1971 (Plate 7, Figures 1-3)

Discoaster bifax Bukry, 1971

Discoaster binodosus Martini, 1958

Discoaster bollii Martini and Bramlette, 1963 (Plate 9, Figure 4)

Discoaster braarudii Bukry, 1971

Discoaster brouweri Tan Sin Hok. 1927 (Plate 6, Figure 3)

Discoaster calcaris Gartner, 1967 (Plate 6, Figures 4, 5)

Discoaster challengeri Bramlette and Riedel, 1954 (Plate 9, Figure 5)

Discoaster cruciformis Martini, 1958

Discoaster deflandrei Bramlette and Riedel, 1954 (Plate 9, Figures $3,6)$

Discoaster delicatus Bramlette and Sullivan, 1961

Discoaster diastypus Bramlette and Sullivan, 1961 (Plate 11, Figures 5,6)

Discoaster distinctus Martini, 1958

Discoaster druggii Bramlette and Wilcoxon, 1967 (Plate 6, Figures 8,9 )

Discoaster elegans Bramlette and Sullivan, 1961

Discoaster exilis Martini and Bramlette, 1963 (Plate 8, Figure 5)

Discoaster formosus Martini and Worsley, 1971

Discoaster hamatus Martini and Bramlette, 1963 (Plate 6, Figure 6)

Discoaster intercalaris Bukry, 1971

Discoaster kugleri Martini and Bramlette, 1963

Discoaster lautus Boudreaux and Hay, 1967

Discoaster lenticularis Bramlette and Sullivan, 1961

Discoaster lodoensis Bramlette and Riedel, 1954

Discoaster loeblichii Bukry, 1971 (Plate 9, Figures 7, 8)

Discoaster mirus Deflandre, 1954

Discoaster mohleri Bukry and Percival, 1971

Discoaster moorei Bukry, 1971 (Plate 7, Figures 5-8)

Discoaster multiradiatus Bramlette and Riedel, 1954 (Plate 11, Figure 4)

Discoaster neorectus Bukry, 1971 (Plate 6, Figure 7; Plate 9, Figure 9)

Discoaster nephados Hay, 1967

Discoaster nobilis Martini 1961

Discoaster nonaradiatus Bramlette and Sullivan, 1961

Discoaster pentaradiatus Tan Sin Hok, 1927 (Plate 8, Figure 4)

Discoaster perplexus Bramlette and Riedel, 1954

Discoaster pseudovariabilis Martini and Worsley, 1971 (Plate 7, Figure 9); Plate 8, Figure 2)

Discoaster quintueramus Gartner, 1969 (Plate 7, Figure 4)

Discoaster saipanensis Bramlette and Riedel, 1954

Discoaster salisburgensis Stradner, 1961

Discoaster saundersii Hay, 1967

Discoaster septemradiatus (Klumpp, 1953) Martini, 1958

Discoaster signus Bukry, 1971

Discoaster sublodoensis Bramlette and Sullivan, 1961

Discoaster subsurculus Gartner, 1967

Discoaster surculus Martini and Bramlette, 1963 (Plate 8, Figure 1)

Discoaster tamalis Kamptner, 1967

Discoaster tanii Bramlette and Riedel, 1954

Discoaster tanii nodifer Bramlette and Riedel, 1954 (Plate 12, Figure 12)

Discoaster trinidadensis Hay, 1967

Discoaster variabilis Martini and Bramlette, 1963 (Plate 7, Figures 10-14)

Discoaster variabilis decorus Bukry, 1971 (Plate 7, Figures 15-16; Plate 9, Figure 10)

Discoaster wemmelensis Achutan and Stradner, 1969

Discoaster sp. 1 (Plate 11, Figure 3; Plate 12, Figures 9-11) 
TABLE 1 - Continued

Discoaster spp. (Plate 6, Figure 1; Plate 8, Figure 3; Plate 9, Figure 1)

Discoasteroides kuepperi (Stradner, 1959) Bramlette and Sullivan, 1961 (Plate 11, Figures 1, 2)

Discoasteroides megastypus Bramlette and Sullivan, 1961

Ellipsolithus distichus (Bramlette and Sullivan, 1961) Sullivan, 1964

Ellipsolithus macellus (Bramlette and Sullivan, 1961) Sullivan, 1964 (Plate 10, Figure 10)

Emiliania annula (Cohen, 1964) Bukry, 1975 (Plate 1, Figures 14, 15)

Emiliania ovata Bukry, 1973 (Plate 1, Figures 8, 9, 13)

Ericsonia cava (Hay and Mohler, 1967) Perch-Nielsen, 1969

Ericsonia fenestrata (Deflandre and Fert, 1954) Stradner, 1968

Ericsonia obruta Perch-Nielsen, 1971

Ericsonia subdisticha (Roth and Hay, 1967) Roth, 1969

Ericsonia subpertusa Hay and Mohler, 1967

Fasciculithus involutus Bramlette and Sullivan, 1961 (Plate 12, Figure 7)

Fasciculithus janii Perch-Nielsen, 1971 (Plate 12, Figure 1)

Fasciculithus pileatus Bukry, 1973 (Plate 12, Figures 3, 6)

Fasciculithus tympaniformis Hay and Mohler, 1967

Gephyrocapsa caribbeanica Boudreaux and Hay, 1967 (Plate 1, Figures 2, 5)

Gephyrocapsa oceanica Kamptner, 1943 (Plate 1, Figures 1, 3, 4)

Helicosphaera ampliaperta Bramlette and Wilcoxon, 1967 (Plate 2, Figure 1)

Helicosphaera carteri (Wallich, 1877) Kamptner, 1954 (Plate 2, Figure 2)

Helicosphaera compacta Bramlette and Wilcoxon, 1967

Helicosphaera euphratis Haq, 1966

Helicosphaera intermedia Martini, 1965 (Plate 1, Figure 25)

Helicosphaera lophota (Bramlette and Sullivan, 1961) Jafar and Martini, 1975

Helicosphaera obliqua Bramlette and Wilcoxon, 1967

Helicosphaera perchnielsenae (Haq, 1971) Martini, 1975

Helicosphaera recta (Haq, 1966) Jafar and Martini, 1975

Heliscosphaera reticulata Bramlette and Wilcoxon, 1967

Helicosphaera sellii (Bukry and Bramlette, 1969) Jafar and Martini, 1975 (Plate 1, Figures 23, 24)

Helicosphaera seminulum (Bramlette and Sullivan, 1961) Jafar and Martini, 1975

Heliolithus kleinpellii Sullivan, 1964 (Plate 10, Figure 8)

Heliolithus riedelii Bramlette and Sullivan, 1961

Isthmolithus recurvus Deflandre, 1954

Lanternithus minutus Stradner, 1962

Markalius inversus (Deflandre, 1954) Bramlette and Martini, 1964 (Plate 10, Figure 5)

Micrantholithus attenuatus Bramlette and Sullivan, 1961

Minilitha convallis Bukry, 1973 (Plate 1, Figure 21)

Nannotetrina cristata (Martini, 1958) Perch-Nielsen, 1971 (Plate 12, Figure 8)

Nannotetrina fulgens (Stradner, 1960) Stradner 1969

Nannotetrina pappii (Stradner, 1959) Perch-Nielsen, 1971

Neochiastozygus chiastus (Bramlette and Sullivan, 1961) PerchNielsen, 1971

Neochiastozygus concinnus Martini, 1961) Perch-Nielsen, 1971

Neochiastozygus distentus (Bramlette and Sullivan, 1961) PerchNielsen, 1971

Neochiastozygus junctus (Bramlette and Sullivan, 1961) PerchNielsen, 1971

Neococcolithes dubius (Deflandre, 1954) Black, 1967

Neococcolithes protenus (Bramlette and Sullivan, 1961) Perch-

Nielsen, 1971

Peritrachelina joidesa Bukry and Bramlette, 1968

Pontosphaera discopora Schiller, 1925

Pontosphaera japonica (Takayama, 1967) n. comb.

Pontosphaera multipora (Kamptner, 1948) Roth, 1970 (Plate 1, Figure 19)

Pontosphaera ovata (Levin and Joerger, 1967) n. comb.

Pontosphaera pectinata (Bramlette and Sullivan, 1961) Proto Decima, Roth and Rodesco, 1975

Pontosphaera plana (Bramlette and Sullivan, 1961) Haq, 1971

Pontosphaera vigintiforata (Kamptner, 1948) n. comb.
TABLE 1 - Continued

Prinsius bisulcus (Stradner, 1963) Hay and Mohler, 1967

Reticulofenestra coenura (Reinhardt, 1966) Roth, 1970

Reticulofenestra hillae Bukry and Percival, 1971

Reticulofenestra lockeri Müller, 1970

Reticulofenestra oamaruensis (Deflandre, 1954) Stradner, 1968

Reticulofenestra pseudoumbilica (Gartner, 1967) Gartner, 1969 (Plate 2, Figure 8)

Reticulofenestra umbilica (Levin, 1965) Martini and Ritzkowski, 1968

Rhabdosphaera clavigera Murray and Blackman, 1898 (Plate 5, Figures 1, 2)

Rhabdosphaera inflata Bramlette and Sullivan, 1961

Rhabdosphaera perlonga (Deflandre, 1952) Bramlette and Sullivan, 1961

Rhabdosphaera procera Martini, 1969

Rhabdosphaera tenuis Bramlette and Sullivan, 1961

Rhomboaster cuspis Bramlette and Sullivan, 1961 (Plate 12, Figures 13-15)

Scapholithus fossilis Deflandre, 1954

Scyphosphaera amphora Deflandre, 1942 (Plate 3, Figure 5)

Scyphosphaera apsteinii Lohmann, 1902 (Plate 3, Figures 1, 8)

Scyphosphaera globulosa Kamptner 1955 (Plate 3, Figures 3, 4)

Scyphosphaera intermedia Deflandre, 1942 (Plate 3, Figures 6, 7)

Scyphosphaera pulcherrima Deflandre, 1942 (Plate 3, Figure 2)

Sphenolithus abies Deflandre, 1954 (Plate 1, Figure 17)

Sphenolithus anarrhopus Bukry and Bramlette, 1969

Sphenolithus belemnos Bramlette and Wilcoxon, 1967

Sphenolithus capricornutus Bukry and Percival, 1971

Sphenolithus ciperoensis Bramlette and Wilcoxon, 1967

Sphenolithus delphyx Bukry, 1973

Sphenolithus dissimilis Bukry and Percival, 1971

Sphenolithus distentus (Martini, 1965) Bramlette and Wilcoxon, 1967

Sphenolithus heteromorphus Deflandre, 1953 (Plate 1, Figures 10-12)

Sphenolithus moriformis (Brönnimann and Stradner, 1960)

Bramlette and Wilcoxon, 1967 (Plate 1, Figure 16)

Sphenolithus neoabies Bukry and Bramlette, 1969

Sphenolithus orphanknollii Perch-Nielsen, 1971 (Plate 12, Figures 4, 5)

Sphenolithus predistentus Bramlette and Wilcoxon, 1967

Sphenolithus pseudoradians Bramlette and Wilcoxon, 1967

Sphenolithus radians Deflandre, 1952

Sphenolithus spiniger Bukry, 1971 (Plate 12, Figure 2)

Syracosphaera histrica Kamptner, 1941 (Plate 1, Figure 20)

Thoracosphaera operculata Bramlette and Martini, 1964

Thoracosphaera saxea Stradner, 1961 (Plate 2, Figure 7)

Toweius craticulus Hay and Mohler, 1967 (Plate 10, Figure 5)

Toweius eminens (Bramlette and Sullivan, 1961) Perch-Nielsen 1971

Transversopontis latus Müller, 1970

Tribrachiatus contortus (Stradner, 1958) Bukry, 1972

Tribrachiatus orthostylus Shamrai, 1963

Triquetrorhabdulus carinatus Martini, 1965

Triquetrorhabdulus inversus Bukry and Bramlette, 1969

Triquetrorhabdulus rugosus Bramlette and Wilcoxon, 1967 (Plate 5, Figure 12)

Umbilicosphaera mirabilis Lohmann, 1902 (Plate 1, Figure 18)

Zygodiscus sigmoides Bramlette and Sullivan, 1961

Zygrhablithus bijugatus (Deflandre, 1954) Deflandre, 1959

Zygrhablithus simplex Bramlette and Sullivan, 1961

\section{MESOZOIC}

Ahmuellerella octoradiata (Gorka, 1957) Reinhardt, 1966 (Plate 15, Figure 14)

Ahmuellerella sp. aff. octoradiata (Gorka, 1957) Reinhardt, 1966 (Plate 15, Figure 15)

Arkhangelskiella cymbiformis Vershina, 1959

Arkhangelskiella specillata Vershian, 1959

Biscutum constans (Gorka, 1957) Black, 1959 (Plate 15, Figure 1)

Braarudosphaera africana Stradner, 1961 (Plate 15, Figure 2) 
TABLE 1 - Continued

Braarudosphaera bigelowii (Gran and Braarud, 1935) Deflandre 1947

Braarudosphaera discula Bramlette and Riedel, 1954

Broinsonia enormis (Shumenko, 1968) Manivit, 1971 (Plate 14, Figure 4)

Broinsonia lata (Noel, 1969) Noel, 1970 (Plate 15, Figure 3)

Broinsonia parca (Stradner, 1963) Bukry, 1969 (Plate 14, Figure 10)

Broinsonia signata (Noel, 1969) Noel, 1970

Chiastozygus cuneatus (Lyulyeva, 1967) Cepek and Hay, 1969

Chiastozygus litterarius (Gorka, 1957) Manivit, 1971

Corollithion achylosum (Stover, 1966) Thierstein, 1971

Corollithion signum Stradner, 1963

Crepidolithus thiersteinii Roth, 1973

Cretarhabdus conicus Bramlette and Martini, 1964

Cretarhabdus coronadventis Reinhardt, 1966 (Plate 14, Figure 8)

Cretarhabdus crenulatus Bramlette and Martini, 1964 emend. Thierstein, 1971 (Plate 16, Figure 2)

Cretarhabdus loriei Gartner, 1968

Cretarhabdus schizobrachiatus (Gartner, 1968) Bukry, 1969

Cretarhabdus surirellus (Deflandre, 1954) Reinhardt, 1970

Cribrosphaerella ehrenbergii (Arkhangelsky, 1912) Deflandre, 1952 (Plate 14, Figure 1)

Cruciellipsis chiastia (Worsley, 1971) Thierstein, 1972 (Plate 14, Figure 2)

Cylindralithus coronatus Bukry, 1969

Cylindralithus gallicus (Stradner, 1963) Bramlette and Martini, 1964

Cylindralithus serratus Bramlette and Martini, 1964

Cyclagelosphaera margerellii Noel, 1965

Diazomatolithus lehmanii Noel, 1965

Discorhabdus ignotus (Gorka, 1957) Perch-Nielsen, 1968

Eiffellithus anceps (Gorka, 1957) Reinhardt and Gorka, 1967 (Plate 15 , Figure 17)

Eiffellithus eximius (Stover, 1966) Perch-Nielsen, 1968

Eiffellithus trabeculatus (Gorka, 1957) Reinhardt and Gorka, 1967

Eiffellithus turriseiffeli (Deflandre, 1954) Reinhardt, 1965

Gartnerago obliquum (Stradner, 1963) Reinhardt, 1970 (Plate 14, Figure 11)

Gartnerago striatum (Stradner, 1963) Forchheimer, 1972

Hayesites albiensis Manivit, 1971

Kamptnerius magnificus Deflandre, 1959 (Plate 14, Figure 12)

Lithastrinus grilli Stradner, 1962 (Plate 16, Figure 1)

Lithastrinus floralis Stradner, 1962 (Plate 16, Figures 7, 9)

Lithraphidites carniolensis Deflandre, 1963

Lithraphidites quadratus Bramlette and Martini, 1964 (Plate 13, Figures $8,15,16$ )

Lucianorhabdus cayeuxii Deflandre, 1959

Manivitella pemmatoidea (Deflandre, 1965) Thierstein, 1971 (Plate 14, Figure 7)

Markalius circumradiatus (Stover, 1966) Perch-Nielsen, 1968

Markalius inversus (Deflandre, 1954) Bramlette and Martini, 1964

Marthasterites furcatus (Deflandre, 1954) Deflandre, 1959

Micrantholithus hochschulzii (Reinhardt, 1966) Thierstein, 1971

Micrantholithus obtusus Stradner, 1963

Microrhabdulus decoratus Deflandre, 1959 (Plate 13, Figure 1)

Microrhabdulus stradneri Bramlette and Martini, 1964 (Plate 13, Figure 2; Plate 14, Figure 9)

Micula mura (Martini, 1961) Bukry, 1973 (Plate 13, Figures 5, 11-13)

Micula pyramida (Gardet, 1955) Thierstein, 1974

Micula staurophora (Gardet, 1955) Stradner, 1963 (Plate 13, Figures 7,14 )

Nannocomus truittii Broennimann, 1955 (Plate 16, Figures 3-6)

Parhabdolithus angustus (Stradner, 1963) Stradner, Adamiker and Maresch, 1968

Parhabdolithus asper (Stradner, 1963) Manivit, 1971 (Plate 14, Figures 3,6)

Parhabdolithus embergeri (Noel, 1958) Stradner, 1963 (Plate 16, Figure 10)

Parhabdolithus splendens (Deflandre, 1953) Noel, 1969 (Plate 15, Figures 8,16)

Podorhabdus albianus Black, 1967
TABLE 1 - Continued

Podorhabdus decorus (Deflandre, 1954) Thierstein, 1972

Podorhabdus dietzmannii (Reinhardt, 1965) Reinhardt, 1967

Prediscosphaera cretacea (Arkhangelsky, 1912) Gartner, 1968 (Plate 15, Figures 5, 9)

Prediscosphaera spinosa (Bramlette and Martini, 1964) Gartner, 1968

Reinhardtites anthoporus (Deflandre, 1959) Perch-Nielsen, 1968

Reinhardtites fenestratus (Worsley, 1971) Thierstein, 1972 (Plate 15 , Figure 4)

Rucinolithus hayi Stover, 1966

Rucinolithus irregularis Thierstein, 1972

Rucinolithus sp. aff. R. magnus Bukry, 1975 (Plate 16, Figures 11,12 )

Stephanolithion laffittei Noel, 1970

Tegumentum stradneri Thierstein, 1972 (Plate 15, Figure 13)

Tetralithus aculeus (Stradner, 1961) Gartner, 1968

Tetralithus gothicus Deflandre, 1959 (Plate 13, Figure 3)

Tetralithus malticus Worsley, 1971

Tetralithus obscurus Deflandre, 1959

Tetralithus premurus Bukry, 1973 (Plate 13, Figures 4, 6)

Tetralithus quadratus Stradner, 1961

Tetralithus trifidus (Stradner, 1961) Bukry, 1973 (Plate 15, Figures 10,11)

Tranolithus exiguus Stover, 1966 (Plate 14, Figure 5)

Tranolithus gabalus Stover, 1966

Tranolithus orionatus Stover, 1966 (Plate 15, Figure 6)

Vagalapilla matalosa (Stover, 1966) Thierstein, 1973 (Plate 15, Figure 7)

Vagalapilla stradneri Thierstein, 1972

Watznaueria barnesae (Black, 1959) Perch-Nielsen, 1968 (Plate 16, Figure 8)

Watznaueria biporta Bukry, 1969

Watznaueria britannica (Stradner, 1963) Reinhardt, 1964

Watznaueria oblonga Bukry, 1969

Watznaueria ovata Bukry, 1969 (Plate 15, Figure 12)

Zygodiscus diplogrammus (Deflandre, 1954) Gartner, 1968

Zygodiscus elegans Gartner, 1968

Zygodiscus spiralis Bramlette and Martini, 1964

Author: Thierstein (1971), Roth (1973).

Age: Upper Albian.

The upper limit of this zone was not detected in Leg 40. The Lithraphidites alatus and Corollithion exiguum zones, that should correspond to the Cenomanian and lower Turonian, were not recognized. Cenomanian and lower Turonian are therefore assumed to be absent at Sites 363 and 364 . Another possibility would be the absence of Cenomanian and lower Turonian markers for ecological reasons.

\section{Micula staurophora Zone}

Definition: Interval from the first occurrence of Micula staurophora to the first occurrence of Marthasterites furcatus.

Author: Manivit (1971).

Age: Upper Turonian to lower Coniacian.

\section{Marthasterites furcatus Zone}

Definition: Interval from the first occurrence of Marthasterites furcatus to the first occurrence of Broinsonia parca.

Author: Cepek and Hay (1969), modified PerchNielsen (1977).

Age: Coniacian and Santonian.

This zone was recognized in Leg 40 at Sites 363 and 364 , but a coring gap prevents establishing here the true ranges of $M$. furcatus and $B$. parca. 
TABLE 2

Cretaceous Coccolith Zonation Used for Leg 40 Sites 361, 363, and 364

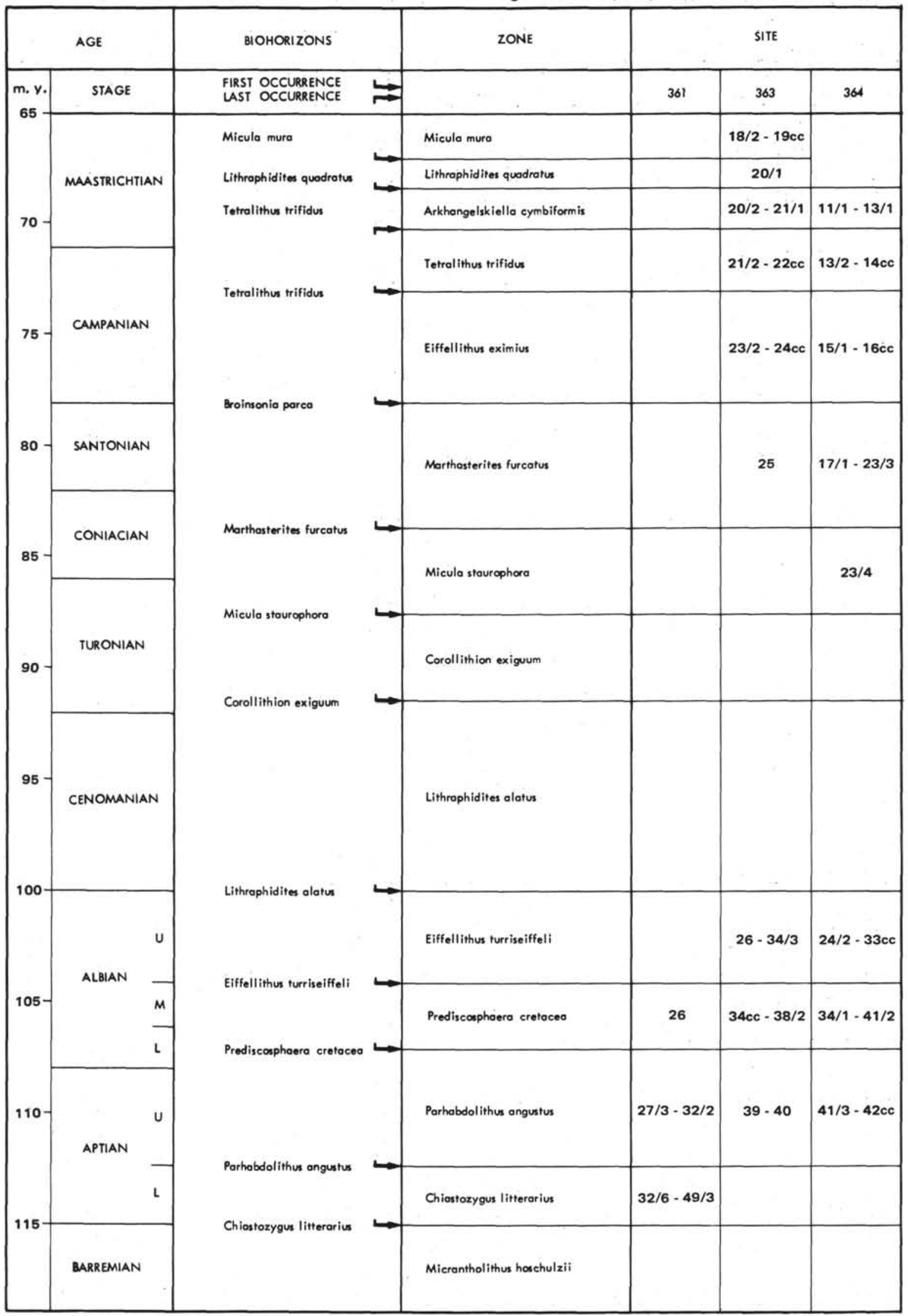




\section{Eiffellithus eximius Zone}

Definition: Interval from the first occurrence of Broinsonia parca to the first occurrence of Tetralithus trifidus.

Author: Roth (1973), modified this paper.

Age: Campanian.

This stratigraphic interval was subdivided by Bukry (1973) and Roth (1973) in Eiffellithus eximius $(=E$. augustus of Bukry) Zone, from the first Broinsonia parca to the last Eiffellithus eximius, and Broinsonia parca Zone from the last Eiffellithus eximius to the first Tetralithus trifidus. At Sites 363 and 364 the last occurrence of Eiffellithus eximius is above the first occurrence of Tetralithus trifidus. Thus the zone defined by Bukry and Roth as Broinsonia parca Zone is not applicable.

\section{Tetralithus trifidus Zone}

Definition: Interval from the first to the last occurrence of Tetralithus trifidus.

Author: Bukry and Bramlette (1970).

Age: Upper Campanian to lower Maestrichtian.

\section{Arkhangelskiella cymbiformis Zone}

Definition: Interval from the last occurrence of Tetralithus trifidus to the first occurrence of Lithraphidites quadratus.

Author: Perch-Nielsen (1972), modified Martini (1976).

Age: Lower to middle Maestrichtian.

\section{Lithraphidites quadratus Zone}

Definition: Interval from the first occurrence of Lithraphidites quadratus to the first occurrence of Nephrolithus frequens in high latitudes or Micula mura in low latitudes.

Author: Cepek and Hay (1969).

Age: Middle Maestrichtian.

\section{Micula mura Zone}

Definition: Interval from the first occurrence of Micula mura to the last occurrence of Arkhangelskiella cymbiformis and other Cretaceous species (Cretaceous extinction plane).

Author: Martini (1969).

Age: Upper Maestrichtian.

\section{Tertiary-Quaternary}

The subdivision of the Tertiary and Quaternary part of the stratigraphic sequences, the events on which they are based, and the age assignments of the cores sampled are reported in Tables 3A and 3B. The zonation used is very close to the standard zonation of Martini (1971). Where they seemed more reliable, some zones or subzones were replaced by those of Bukry $(1973,1975)$. Some minor changes in respect to Martini's zonation are also determined by the application of a different species nomenclature.

The correlations between Martini's standard zonation, the Bukry zones and subzones, and the zonation used in this report are shown in Tables $4 \mathrm{~A}$ and $4 \mathrm{~B}$. In similar zonal correlations of the literature, the zones are often compared without consideration of their definitions which results in incorrect correlations. For instance, the Oligocene Sphenolithus prdistentus; $S$. distentus, and $S$. ciperoensis zones of Bukry have different definitions compared with the zones of the same names of Martini, and do not represent the same stratigraphic intervals.

Reference is made to Tables 3A and 3B for zonal sequences and boundaries used in this report. Some remarks on the major differences in comparison with the Martini and Bukry zonations are made in the following.

Lower Paleocene was recovered in Leg 40 at Sites 361,363 , and 364 , but in none of them could the fine biostratigraphic subdivision of Martini be applied. It had to be replaced by a Cruciplacolithus tenuis Zone extending from the Cretaceous extinction plane to the first occurrence of Fasciculithus tympaniformis.

The use of the Discoaster nobilis Zone of Bukry instead of the Heliolithus riedelii Zone of Martini was preferred because the appearance of $H$. riedelii occurs in Site 363 before the first discoasters in the Heliolithus kleinpellii Zone. $H$. riedelii is very common in the Discoaster nobilis Zone at Site 363.

The lower Eocene nannofloras are characterized by the sudden appearance and rapid evolution of the "Tribrachiatus" group of which Rhomboaster cuspis Bramlette and Sullivan (= Marthasterites bramlettei Brönnimann and Stradner, 1960) represents the first stage. The Tribrachiatus contortus Zone as used here is thus the same as the Marthasterites contortus Zone of Martini. Bukry uses for the lower boundary of this zone the first occurrence of Discoaster diastypus. At Sites 361 and 363 Rhomboaster cuspis and Discoaster diastypus occur first at the same level. Instead at Site 364, and in some land sections such as the Lodo Formation (Bramlette and Sullivan, 1961), and the Pederobba and Possagno sections (Proto Decima, 1966; Proto Decima et al., 1975), the first Discoaster diastypus occur slightly above the Rhomboaster cuspis appearance.

Bukry's zonation was employed for the subdivision of the middle Eocene. The Nannotetrina fulgens Zone as used in this report is the same as the Nannotetrina quadrata Zone of Bukry and much more extended than the Chiphragmalithus alatus Zone of Martini. The absence of Rhabdosphaera gladius in the investigated sections prevents recognition of the Discoaster tanii nodifer Zone of Martini. The first appearance of Reticulofenestra umbilica is here considered more reliable than the last occurrence of Chiasmolithus solitus. The range of this latter species overlaps at Site 360 with Chiasmolithus oamaruensis.

For the upper Eocene, Oligocene, and Miocene the zonation used corresponds to the standard zonation of Martini. The Sphenolithus predistentus Zone as defined by Bukry (1973) is not present at Sites 362A and 363 and also not in some land sections, where the ranges of Reticulofenestra umbilica and Sphenolithus distentus are overlapping. In the upper Miocene the first occurrence of Amaurolithus primus and A. delicatus was considered as in Bukry's zonation to subdivide the Discoaster quinqueramus Zone.

For the Pliocene and Pleistocene the zonation used is a compromise between the zonations of Martini and Bukry. The Emiliania ovata Zone corresponds to the 
TABLE 3A

Pleistocene-Middle Oligocene Coccolith Zonation Used for Leg 40 Sites 360, 361, 362, 362A, 363, and 364

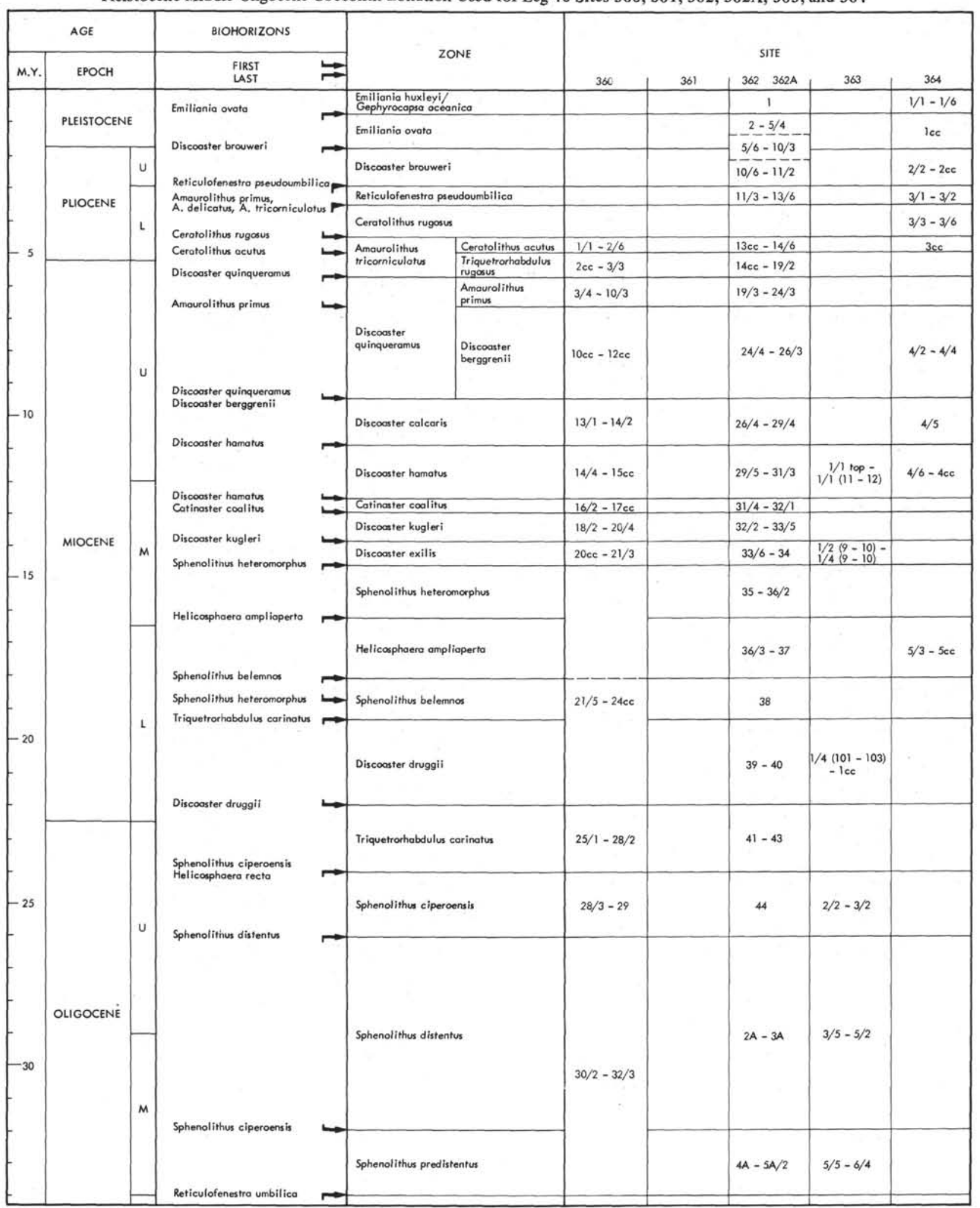

NP 14 Pseudoemiliania lacunosa Zone of Martini. The name of the zone was changed because of the taxonomic revision by Bukry (1975). Because of the difficulty of recognizing Emiliania huxleyi in the light microscope, the Gephyrocapsa oceanica and Emiliania huxleyi zones were combined.

\section{SITE 360}

Cape Basin (lat $35^{\circ} 50.75^{\prime} \mathrm{S}$, long $18^{\circ} 05.79^{\prime} \mathrm{E}$, water depth $2949 \mathrm{~m}$ )

Abundant nannofossil assemblages ranging in age from the lower Pliocene Ceratolithus acutus Subzone to 
TABLE 3B

Middle Oligocene-Paleocene Coccolith Zonation Used for Leg 40 Sites 360, 361, 362, 362A, 363, and 364

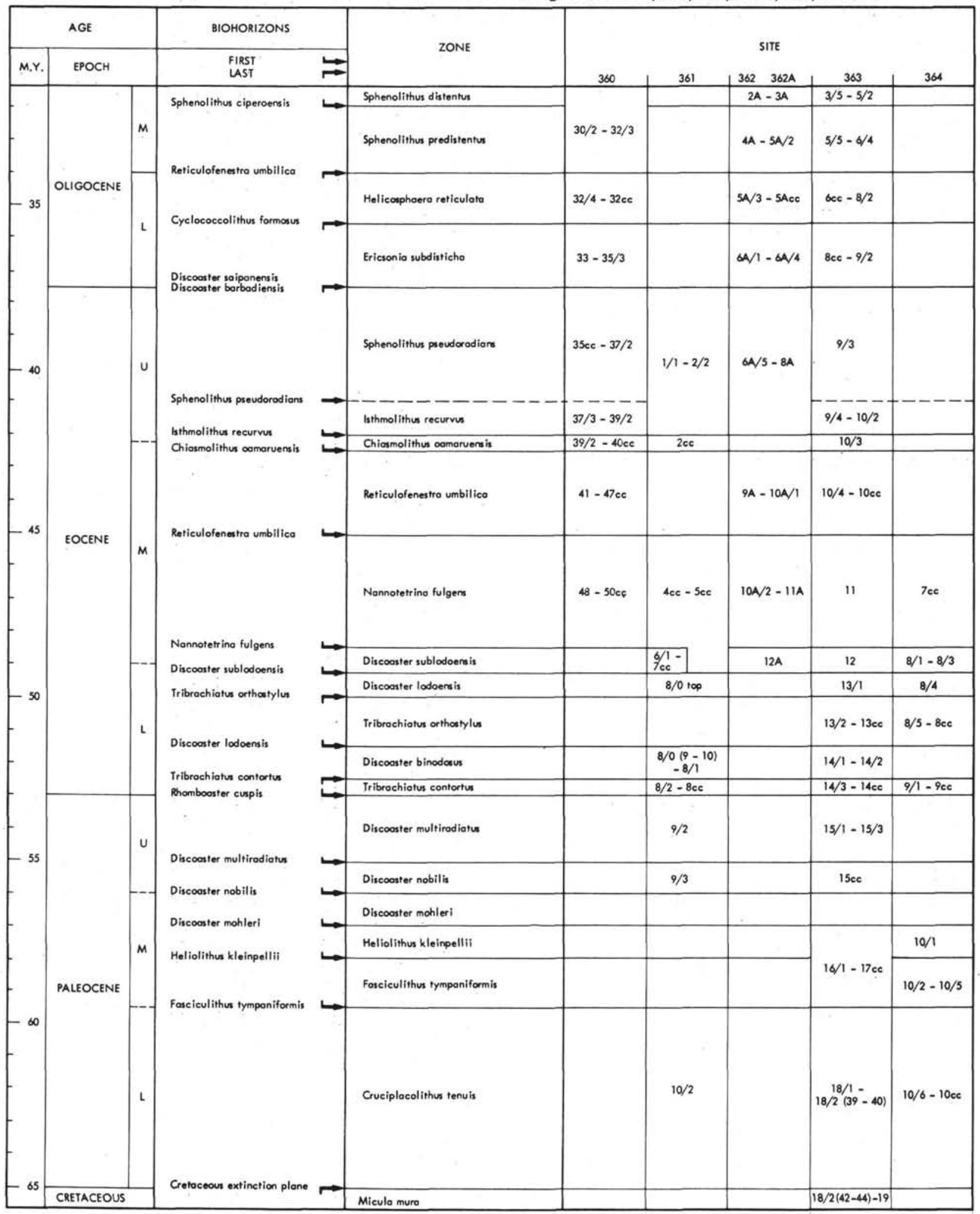

the middle Eocene Nannotetrina fulgens Zone were encountered at this site. The stratigraphic distribution of the calcareous nannofossils and some additional information on the abundance and preservation of the assemblages are shown in Tables $5 \mathrm{~A}, 5 \mathrm{~B}$, and $5 \mathrm{C}$.
Discoasters are rare in the lower Pliocene and lower Oligocene, frequent in the remainder of the section, and particularly well preserved in the Miocene; the rosette Discoaster barbadiensis, however, is generally scarce in the upper Eocene. Chiasmolithus oamaruensis and 
TABLE 4A

Correlation of the Pleistocene-Middle Oligocene Coccolith Zonation Used in This Report with the Standard Nannoplankton Zonation of Martini (1971) and the Nannoplankton Zones and Subzones of Bukry $(1973,1975)$

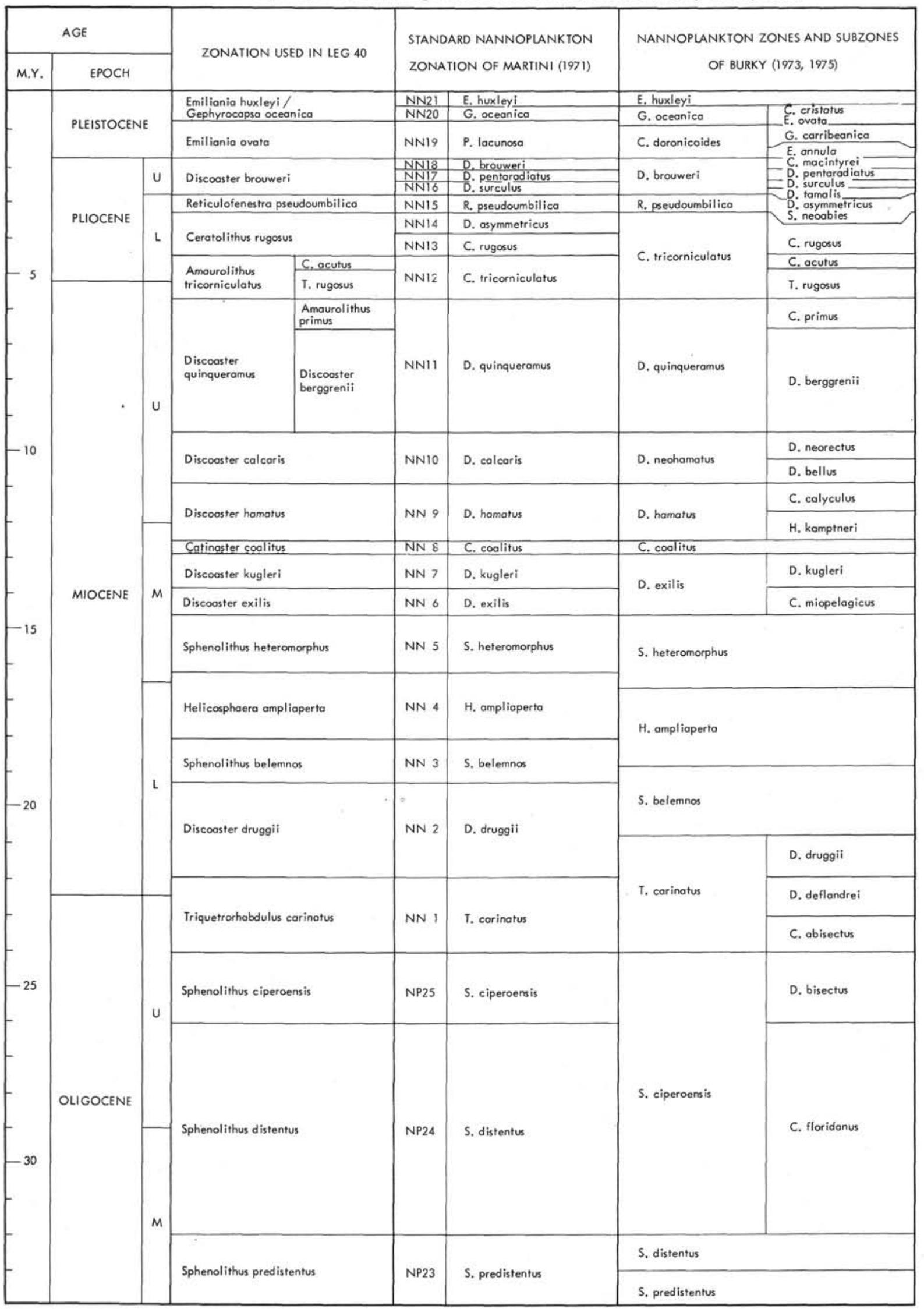


TABLE 4B

Correlation of the Middle Oligocene-Paleocene Coccolith Zonation Used in This Report with the Standard Nannoplankton Zonation of Martini (1971) and the Nannoplankton Zones and Subzones of Bukry $(1973,1975)$

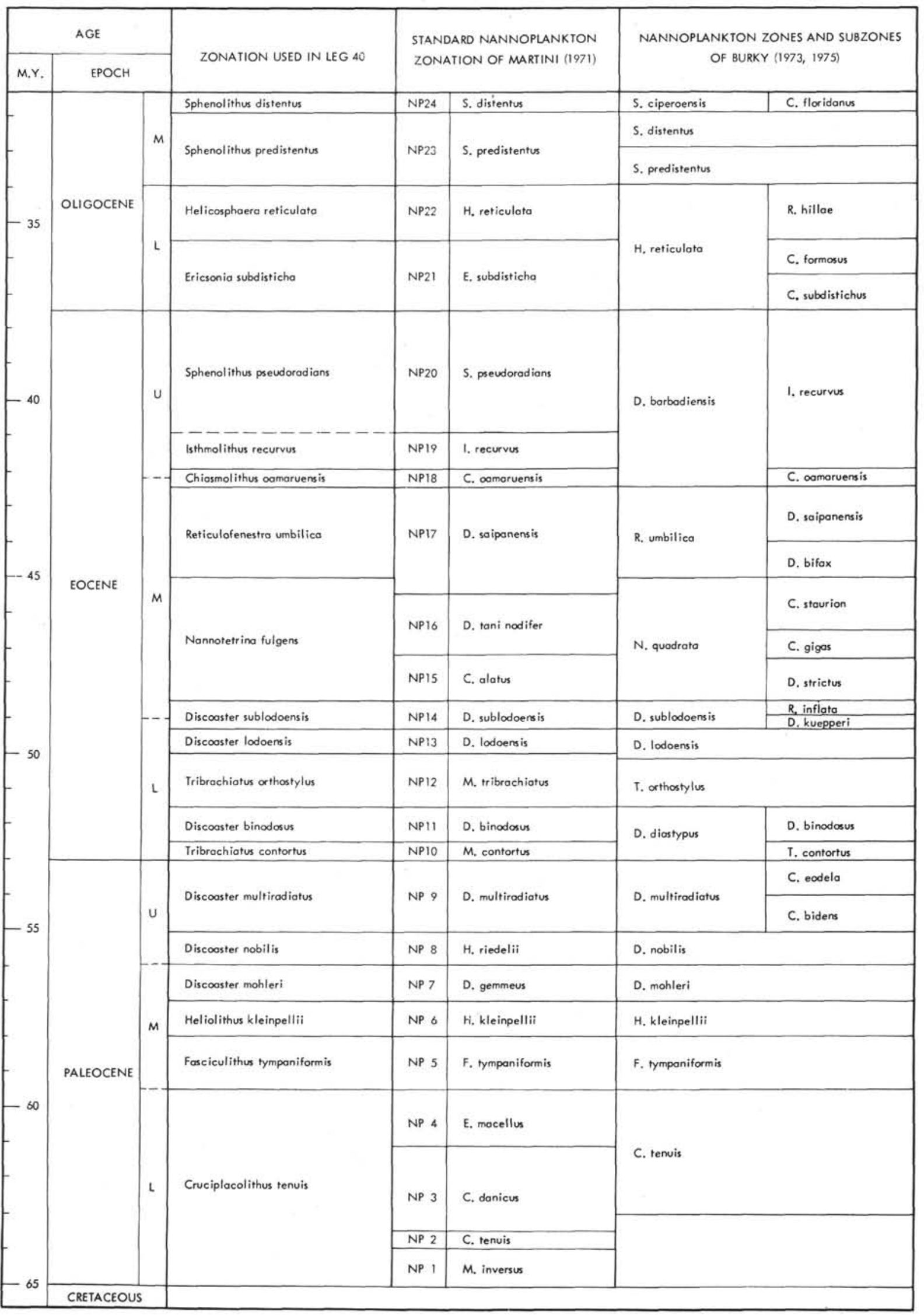


TABLE 5A

Distribution of Pliocene-Upper Miocene Calcareous Nannofossils at Site 360

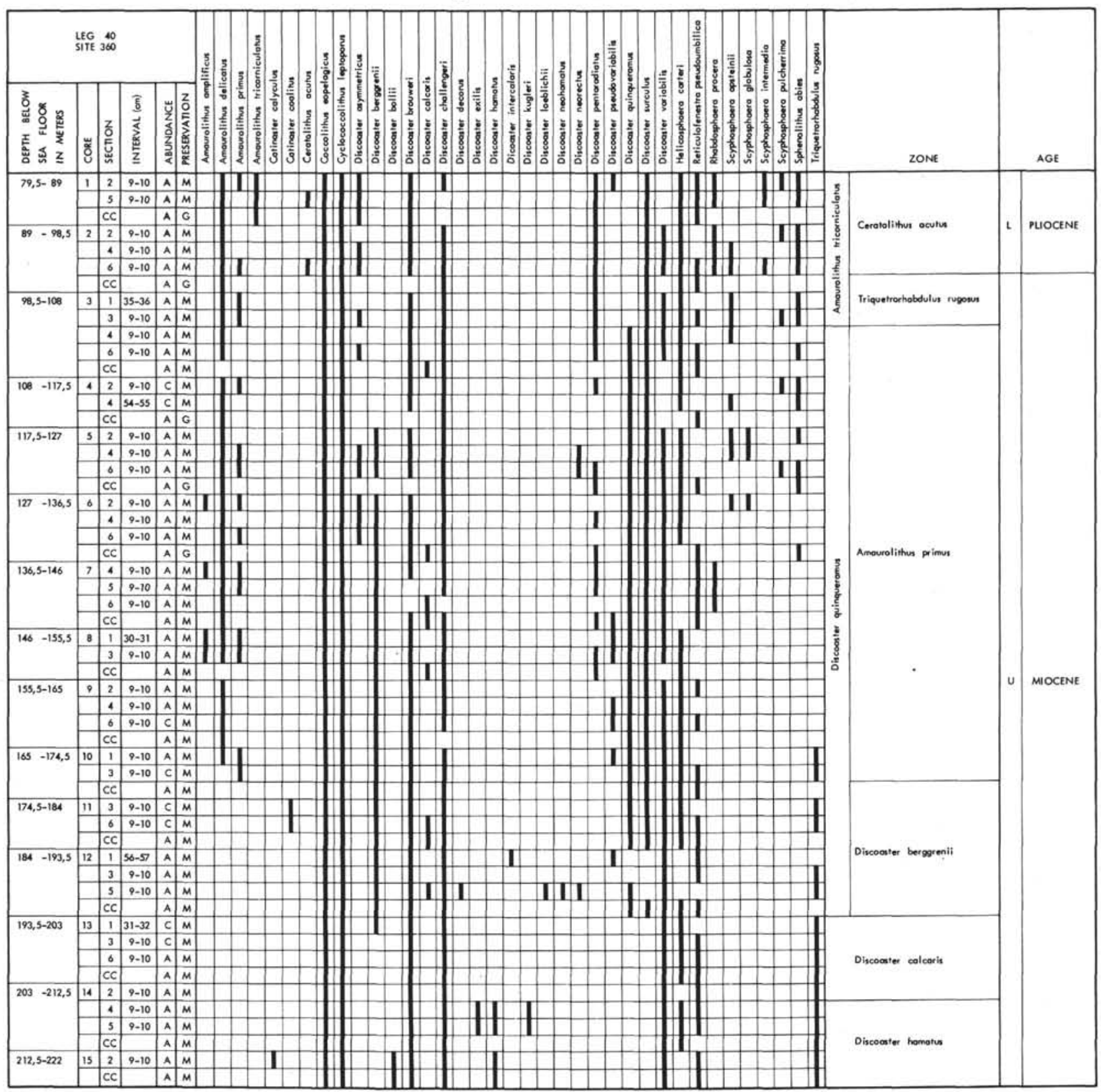

Isthmolithus recurvus are very abundant in Cores 34, 35, and 36 of upper Eocene and lower Oligocene age; Neococcolithes dubius is very frequent in the middle Eocene part of the sequence. The abundance here of these forms, which are extremely rare or absent in tropical waters, and the general scarcity of the genus Sphenolithus and Discoaster barbadiensis, furnish indications of temperate water conditions. The range of Chiasmolithus oamaruensis in this sequence differs from that of the Mediterranean regions and is the same as known for New Zealand. Characteristic is the total absence of near shore indicators such as Braarudosphaera, Micrantholithus, Pemma. In the middle/lower Oligocene the abundance of the holococcolith Zygrhablithus bijugatus seems to suggest a basin less than 1000 meters deep.
In the Oligocene the absence of Sphenolithus ciperoensis prevents separating the Sphenolithus distentus and Sphenolithus predistentus zones. A detailed zonation was not possible for the lower Miocene. Sphenolithus belemnos and $S$. heteromorphus have their last occurrence at the same level (Core 21, Section 6); the Helicosphaera ampliaperta and Sphenolithus heteromorphus zones cannot be recognized therefore and are probably missing. A sedimentary gap between the lower and middle Miocene is therefore possible.

The Miocene-Pliocene boundary by means of paleomagnetic correlations is dated at 5.2 m.y. (Ryan, Cita, et al., 1974), the first Ceratolithus acutus at 4.9 m.y. Thus the Miocene-Pliocene boundary at this site, according to nannoplankton is placed in Core 3. The 
TABLE 5B

Distribution of Middle Miocene-Lower Oligocene Calcareous Nannofossils at Site 360

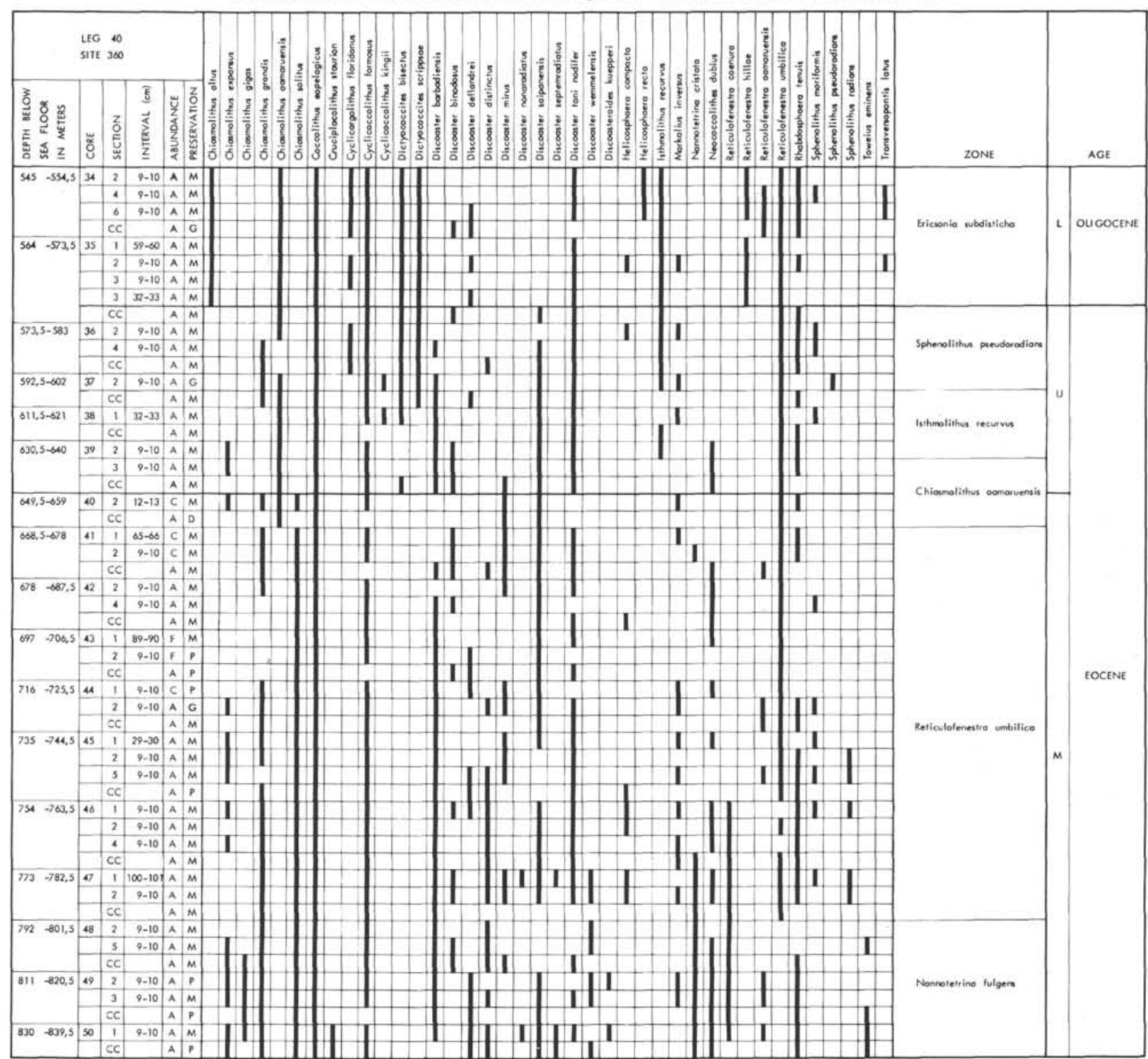

Oligocene-Miocene boundary falls between the last occurrence of Helicosphaera recta in Core 28, Section 3 and the first occurrence of Discoaster druggii in Sample 24, CC. The Eocene-Oligocene boundary, marked by the last occurrence of Discoaster saipanensis is placed in Core 35 between Section 3 and the core catcher. Frequent Nannotetrina cristata and Chiasmolithus gigas, suggesting a middle Eocene age, characterize the assemblages at the bottom of the site. Typical Nannotetrina fulgens are not present at this site.

SITE 361

Cape Basin (lat $35^{\circ} 03.97^{\prime} \mathrm{S}$, long $15^{\circ} 26.91^{\prime} \mathrm{E}$, water depth $4549 \mathrm{~m}$ )

Nannofossil assemblages of upper Eocene to lower Paleocene and middle Albian to lower Aptian age occur at this site.
The stratigraphic distribution of the nannofossils and information on abundance and preservation of the assemblages are shown on Tables 6 and 7.

Poorly preserved upper Eocene nannofossils are present in Cores 1 and 2. The absence of Sphenolithus pseudoradians does not allow us to distinguish between the Isthmolithus recurvus and Sphenolithus pseudoradians zones.

Cores 3 and 4 are barren. Sample 4, CC to Core 7 contain moderately preserved middle Eocene assemblages. In Sample 4, CC and Core 5 the presence of Rhabdosphaera inflata above the first Nannotetrina fulgens and Chiasmolithus gigas and the abundance of Discoaster sublodoensis suggest mixed assemblages between the Nannotetrina fulgens and Discoaster sublodoensis zones. The middle-lower Eocene Discoaster sublodoensis Zone is present in Core 7. The 
TABLE 5C

Distribution of Lower Oligocene-Middle Eocene Calcareous Nannofossils at Site 360

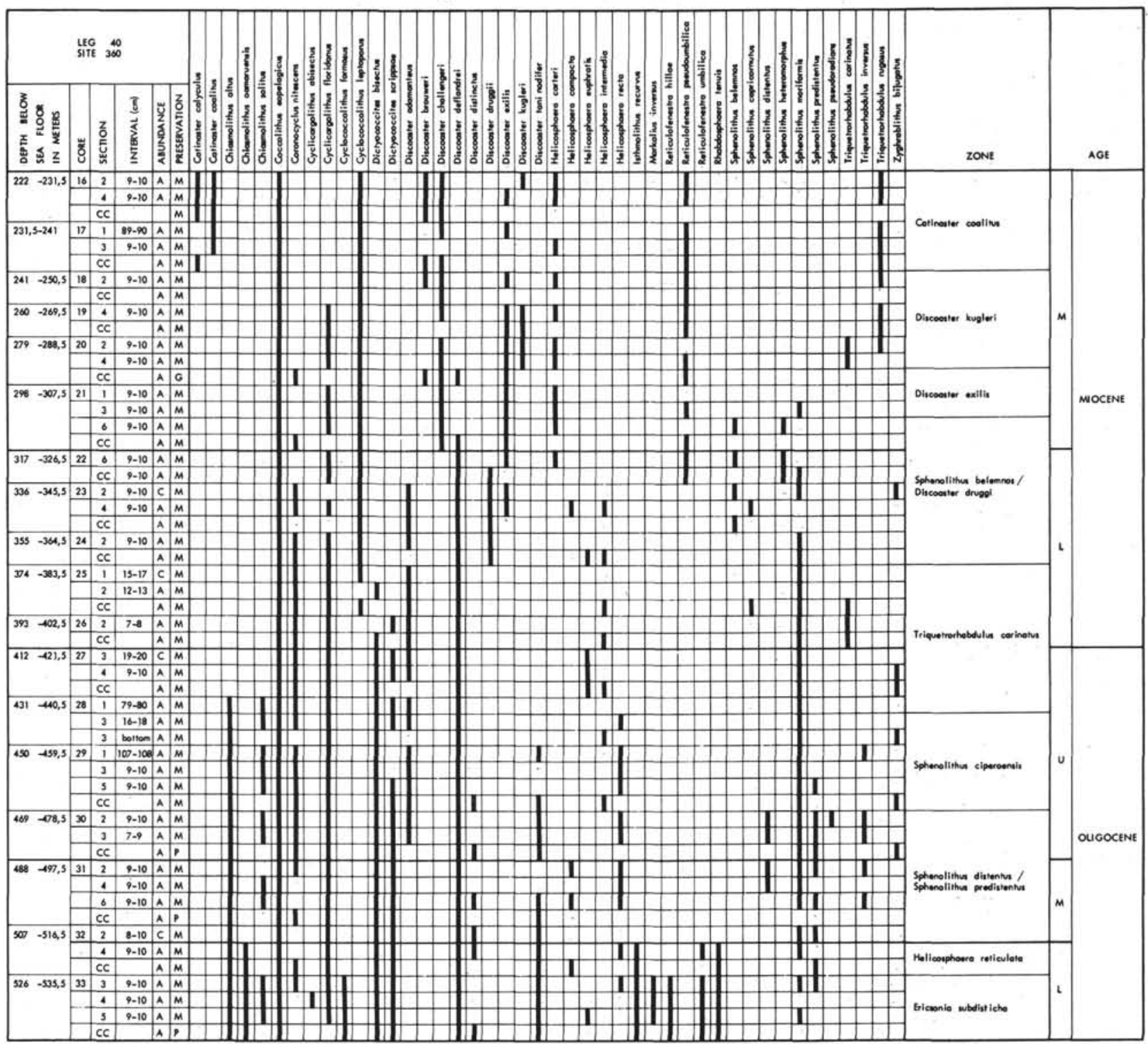

interval top of Core 8 to Core 9, Section 2 represents a complete but strongly condensed sequence of lower Eocene to upper Paleocene nannoplankton zones. A problematic oval-shaped nannofossil (Plate 2, Figures 9-12) is frequent in the Discoaster binodosus Zone and, from present observations, seems to be limited to it. It was also found at Site 362 in a Pleistocene-Pliocene sample containing a reworked nannoflora of the Discoaster binodosus Zone. A very interesting evolution of the Tribrachiatus group is recorded in Core 8. A barren interval in the lower part of Core 9 separates the upper Paleocene from the lower Paleocene Cruciplacolithus tenuis Zone, present in Core 10, Section 2. Contamination from above and barren samples characterize the lower part of Core 10 and Core 11. Cores 12 to 25, which are not included in Table 7, contain very rare, small Watznaueria that only allow for a general Cretaceous dating. The Prediscosphaera cretacea, Parhabdolithus angustus, and Chiastozygus litterarius zones of middle Albian to lower Aptian age have been recognized in the poor nannoflora associations from Core 26 to the bottom of the hole. The concurrence of Chiastozygus litterarius and Micrantholithus hoschulzii from Core 33 down is indicative of the lower Aptian Chiastozygus litterarius Zone.

From a paleoecological point of view, the abundance of Isthmolithus recurvus in the upper Eocene and Neococcolithes dubius in the middle and lower Eocene and in the upper Paleocene indicates temperate to cold water conditions for the Tertiary part of the section. The presence of barren intervals, heavily etched coccoliths, concentration of solution-resistant species, and the strong condensation of the lower Eocene sequence suggest deposition near the base of the carbonate compensation depth or a slow burying of organic remains. As far as the Cretaceous paleoecology of Site 361 is concerned, some conclusions can be drawn from the presence of Micrantholithus hoschulzii 
TABLE 6

Distribution of Eocene-Paleocene Calcareous Nannofossils at Site 361

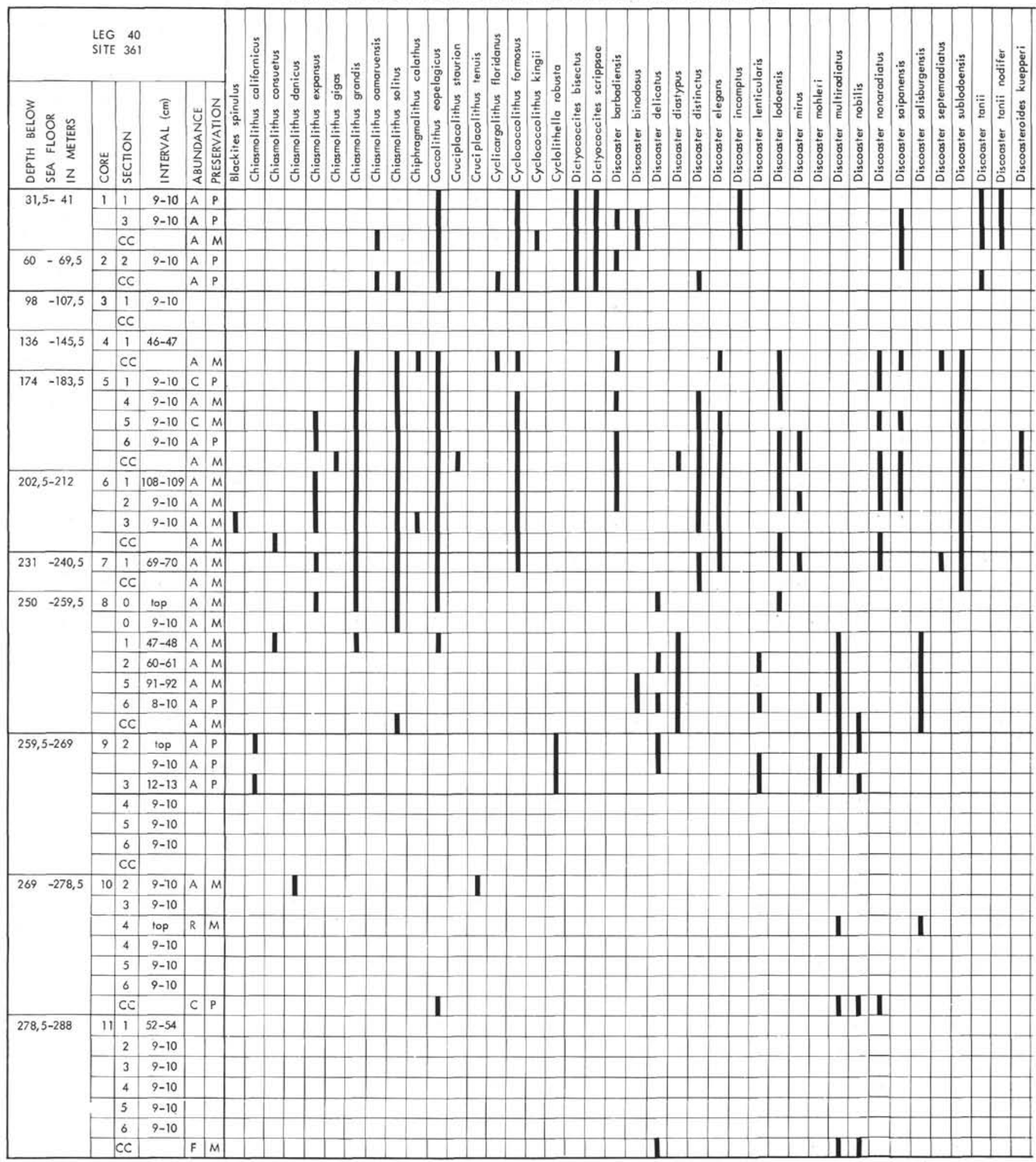

which is considered a temperate species. Unusual associations with floods of Cyclagelosphaera margerelii were found in Samples 33-3, $46 \mathrm{~cm}$ and in $37-1,101 \mathrm{~cm}$. According to Thierstein (1973) this species favored shallow water and platform conditions or a reducing marine environment. All the coccoliths present are solution-resistant species. This fact associated with the occurrence of many barren samples and the dark color (carbonaceous nature) of the sediments indicates bottom conditions unfavorable for coccolith preservation.

\section{HOLES 362 AND 362A \\ Walvis Ridge (lat $19^{\circ} 45.45^{\prime} \mathrm{S}$, long $10^{\circ} 31.95^{\prime} \mathrm{E}$, water depth $1325 \mathrm{~m}$ )}

Sites 362 and 362A, on the Abutment Plateau of the Walvis Ridge, together provide a stratigraphic sequence ranging from Pleistocene to lower Eocene. A 


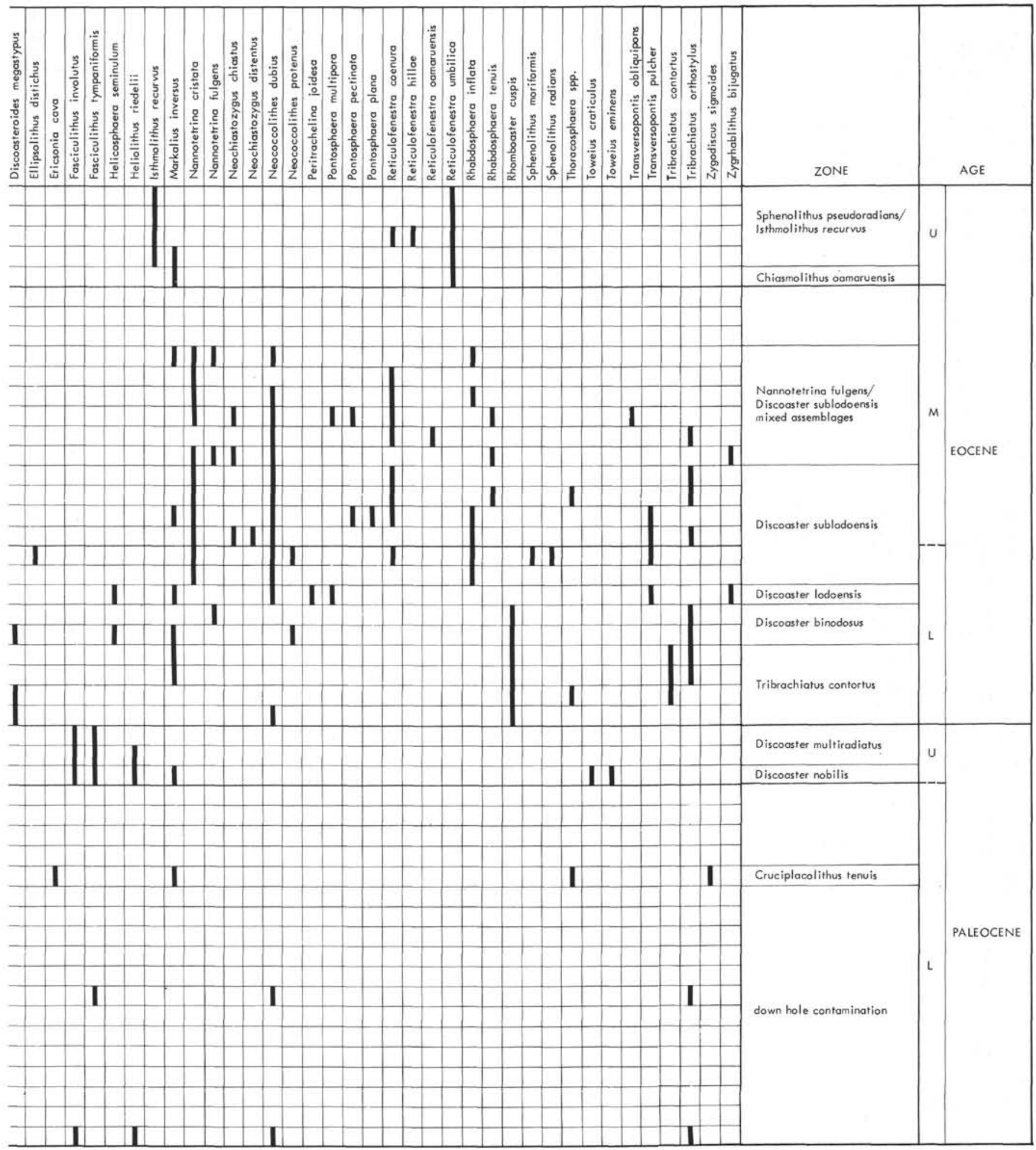

total of 56 cores was obtained, of which 44 were drilled at Site 362 and 12 in the complementary Site $362 \mathrm{~A}$. Calcareous nannofossils are abundant throughout the section. Their stratigraphic distribution and additional data on the abundance and preservation of the assemblages are shown in Tables $8 \mathrm{~A}, 8 \mathrm{~B}$, and 9 .

The upper part of the section from Core 1 to Core 5 , Section 4 is referred to the combined Pleistocene
Emiliania huxleyi/Gephyrocapsa oceanica zones and the Emiliania ovata Zone. The age of the interval Core 5, Section 6 to Core 10, Section 3 is lower Pleistocene or upper Pliocene. Discoasters are rare or even absent in some samples, Gephyrocapsa spp. are generally present. Core Catcher 9 contains very frequent reworked lower Eocene coccoliths of the Discoaster binodosus Zone; the oval-shaped nannofossils (Plate 2, Figures 9-12) found 
TABLE 7

Distribution of Albian-Aptian Calcareous Nannofossils at Site 361

\begin{tabular}{|c|c|c|c|c|c|c|c|c|c|c|c|c|c|c|c|c|c|c|c|c|c|c|c|c|c|c|}
\hline \multicolumn{6}{|c|}{$\begin{array}{ll}\text { LEG } & 40 \\
\text { SITE } & 361\end{array}$} & \multirow[b]{2}{*}{ 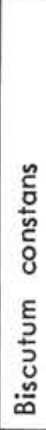 } & 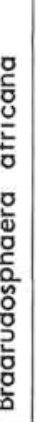 & \multirow{2}{*}{ 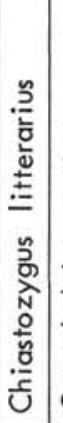 } & & \multirow{2}{*}{ 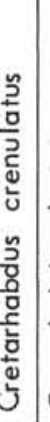 } & \multirow{2}{*}{ 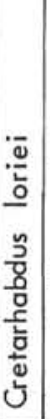 } & \multirow{2}{*}{ 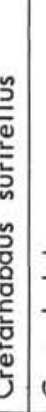 } & \multirow{2}{*}{ 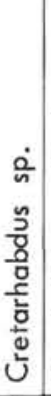 } & \multirow{2}{*}{ 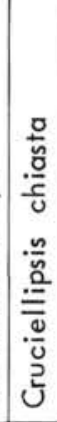 } & \multirow{2}{*}{ :- } & \multirow{2}{*}{ 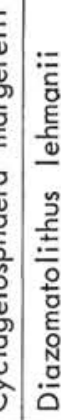 } & $\sim$ & & & 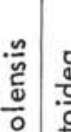 & 总 & $\begin{array}{l}: \overline{\bar{N}} \\
\frac{D}{2} \\
\frac{D}{S} \\
\\
\end{array}$ & 恙 & & & \\
\hline 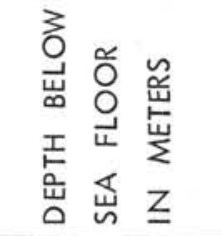 & 㫕 & 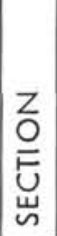 & $\begin{array}{l}\text { 氖 } \\
\text { 岁 } \\
\text { 总 } \\
\underline{\underline{z}}\end{array}$ & 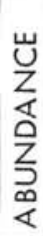 & 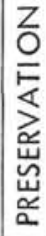 & & 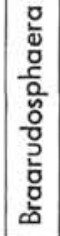 & & 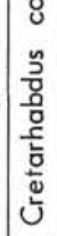 & & & & & & & & 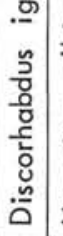 & 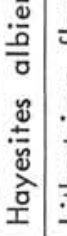 & 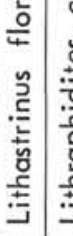 & 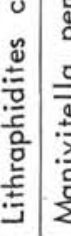 & 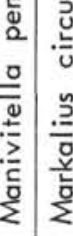 & 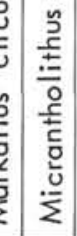 & 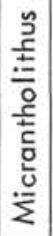 & 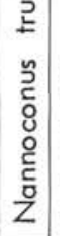 & 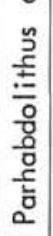 & 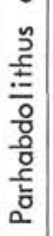 \\
\hline $905,5-915$ & 26 & 2 & $9-10$ & C & P & & & & & & & & & & & & & & & & & & & & & \\
\hline & & 5 & $9-10$ & A & $\mathrm{P}$ & & & & & & & & & & & & & & & & & & & & & \\
\hline & & $\mathrm{CC}$ & & C & M & & & & & & & & & & & & & & & & & & & & & \\
\hline $953-962,5$ & 27 & 3 & $37-39$ & A & $P$ & & & & & & & & & & & & & & & & & & & & & \\
\hline $1005,0-1010$ & 28 & $\mathrm{CC}$ & & $R$ & $M$ & & & & & & & & & & & & & & & & & & & & & \\
\hline $1029-1038,5$ & 29 & 6 & $9-10$ & A & $M$ & & & & & & & & & & & & & & & & & & & & & \\
\hline $1038,5-1048$ & 30 & CC & & C & M & & & & & & & & & & & & & & & & & & & & & \\
\hline $1048-1057,5$ & 31 & 2 & $9-10$ & A & $P$ & & & & & & & & & & & & & & & & & & & & & \\
\hline & & 4 & $9-10$ & A & M & & & & & & & & & & & & & & & & & & & & & \\
\hline & & $\mathrm{CC}$ & & A & M & & & & & & & & & & & & & & & & & & & & & \\
\hline $1057,5-1067$ & 32 & 1 & $9-10$ & C & $P$ & & & & & & & & & & & & & & & & & & & & & \\
\hline & & 2 & $50-51$ & A & M & & & & & & & & & & & & & & & & & & & & & \\
\hline & & 6 & $11-12$ & A & P & & & & & & & & & & & & & & & & & & & & & \\
\hline & & $C C$ & & C & $P$ & & & & & & & & & & & & & & & & & & & & & \\
\hline $1067-1076,5$ & 33 & 2 & 35 & C & $P$ & & & & & & & & & & & & & & & & & & & & & \\
\hline & & 3 & 27 & A & M & & & & & & & & & & & & & & & & & & & & & \\
\hline & & & $37-38$ & A & $P$ & & & & & & & & & & & & & & & & & & & & & \\
\hline & & & 46 & A & $P$ & & & & & & & & & & & & & & & & & & & & & \\
\hline $1076,5-1086$ & 34 & 2 & $40-41$ & C & $P$ & & & & & & & & & & & & & & & & & & & & & \\
\hline & & CC & & C & $P$ & & & & & & & & & & & & & & & & & & & & & \\
\hline $1086-1095,5$ & 35 & 1 & $143-145$ & $\mathrm{~F}$ & M & & & & & & & & & & & & & & & & & & & & & \\
\hline $1095,6-1105$ & 36 & 2 & $42-43$ & $\mathrm{~F}$ & $P$ & & & & & & & & & & & & & & & & & & & & & \\
\hline $1105-1114,5$ & 37 & 1 & 101 & A & M & & & & & & & & & & & & & & & & & & & & & \\
\hline & & $\mathrm{CC}$ & & C & $\mathrm{P}$ & & & & & & & & & & & & & & & & & & & & & \\
\hline $1114,5-1124$ & 38 & 2 & 75 & C & $P$ & & & & & & & & & & & & & & & & & & & & & \\
\hline $1124-1133,5$ & 39 & 2 & $8-9$ & C & $\mathrm{P}$ & & & & & & & & & & & & & & & & & & & & & \\
\hline $1143-1152,5$ & 40 & 3 & $60-61$ & C & $P$ & & & & & & & & & & & & & & & & & & & & & \\
\hline $1162-1171,5$ & 41 & 1 & $91-92$ & C & $P$ & & & & & & & & & & & & & & & & & & & & & \\
\hline $1181-1190,5$ & 42 & 6 & $45-46$ & A & $\mathrm{P}$ & & & & & & & & & & & & & & & & & & & & & \\
\hline $1200-1209,5$ & 43 & 4 & $105-106$ & C & $P$ & & & & & & & & & & & & & & & & & & & & & \\
\hline $1219-1228,5$ & 44 & 2 & bottom & $\mathrm{F}$ & $P$ & & & & & & & & & & & & & & & & & & & & & \\
\hline $1238-1247,5$ & 45 & 3 & bottom & C & M & & & & & & & & & & & & & & & & & & & & & \\
\hline $1257-1266,5$ & 46 & $\mathrm{CC}$ & top & $R$ & M & & & & & & & & & & & & & & & & & & & & & \\
\hline $1266,5-1276$ & 47 & 2 & $121-122$ & C & $P$ & & & & & & & & & & & & & & & & & & & & & \\
\hline $1285,5-1295$ & 48 & $C C$ & & $\mathrm{~F}$ & M & & & & & & & & & & & & & & & & & & & & & \\
\hline $1304,5-1314$ & 49 & 3 & $118-120$ & C & P & & & & & & & & & & & & & & & & & & & & & \\
\hline
\end{tabular}


TABLE 7 - Continued

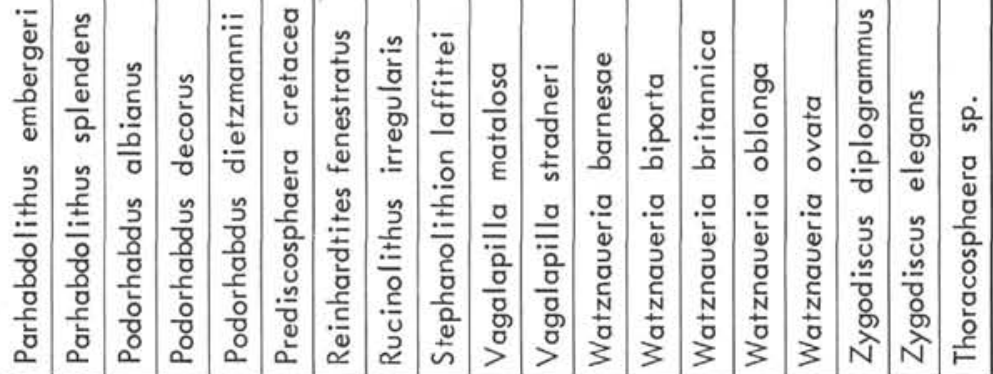

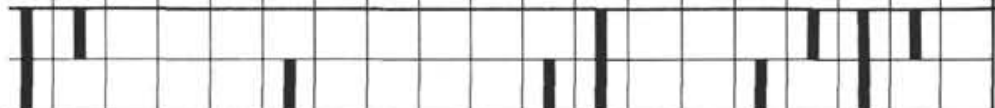

1
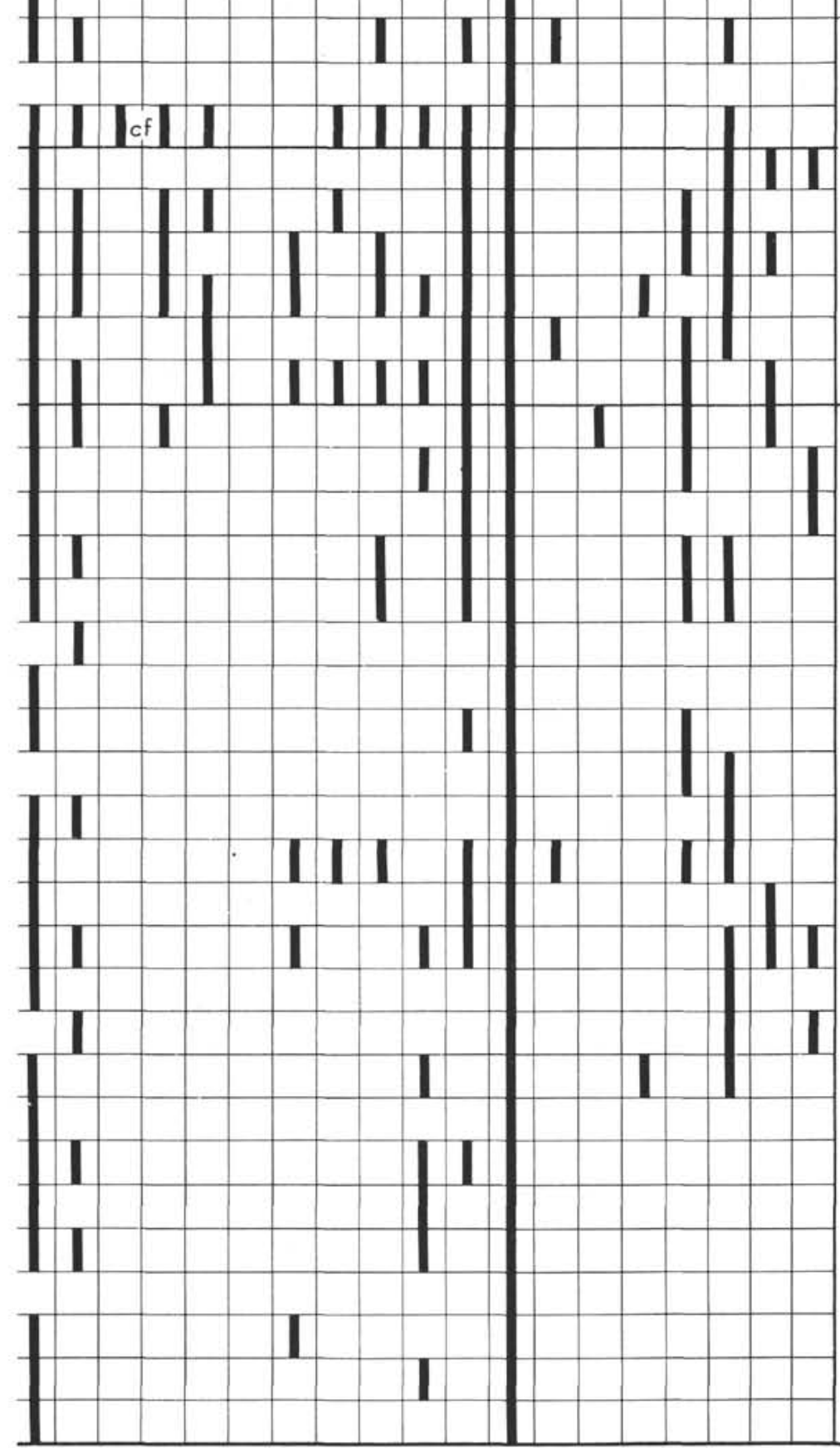

AGE

\section{Prediscosphaera cretacea}

M

ALBIAN

Parhabdolithus angustus

Chiastozygus litterarius 
TABLE 8A

Distribution of Pleistocene-Upper Miocene Calcareous Nannofossils at Site 362

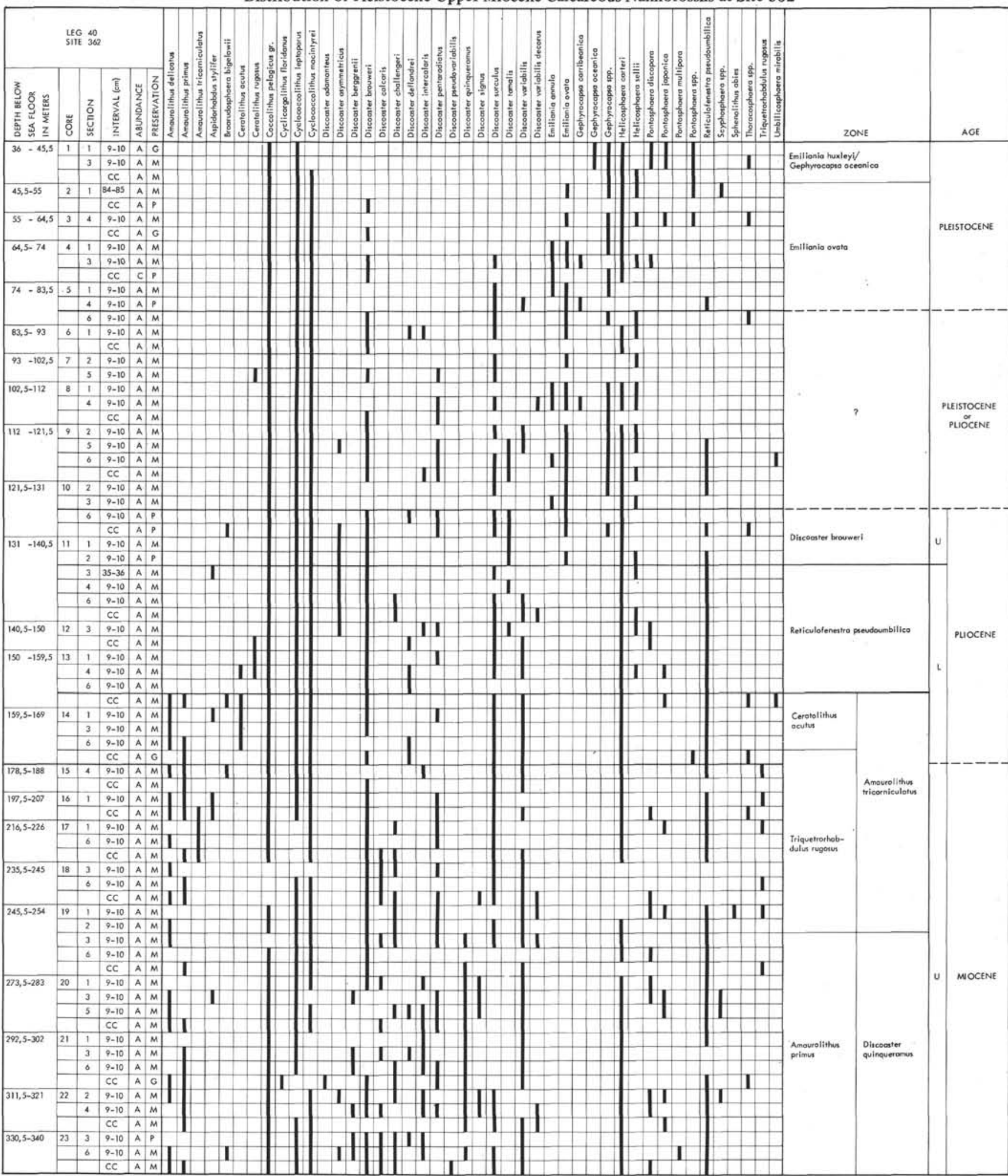

in the same zone of Site 361 are also present. The assemblages in Core 10, Section 6 to Core 11, Section 2 are typical of the lower part of the upper Pliocene Discoaster brouweri Zone, with common Discoaster asymmetricus and D. tamalis present. Part of the lower Pliocene seems to be missing. A continuous sedimentary sequence was recovered from the lowermost Pliocene Ceratolithus acutus Subzone down to the iower-middle Eocene Discoaster sublodoensis Zone. A sharp change in the nannoflora assemblages takes place in the middle and lower Oligocene Sphenolithus distentus, Sphenolithus predistentus, and 
Helicosphaera reticulata zones (Sample 3A, CC to Core $5 \mathrm{~A})$. Normal nannoplankton associations are here replaced by very rich Braarudosphaera horizons. Living braarudosphaeras are abundant in coastal waters and very rare in the open ocean. Their skeletal remains are absent from the deep oceanic sediments, and in many land sections their frequency increases toward the shallowing of the basins. Their significance from the ecological point of view therefore is that of a near-shore indicator. Nevertheless Braarudosphaera layers, as already known from the Oligocene of the South Atlantic and Indian oceans, are associated with open sea planktonic assemblages. In the Oligocene of Hole $362 \mathrm{~A}$, no indications are present for a shallowing of the basin. The ratio of planktonic to benthic foraminifers still remains very high, and no shallow-water forms are present among the rare benthic foraminifers. Thus the significance of these Braarudosphaera layers is not yet clearly understood: they are probably the result of periodic blooms connected with unusual oceanic conditions.

The last occurrence of Discoaster barbadiensis is in Core 7A, Section 3. Discoaster saipanensis ranges somewhat higher: it is present in all the sections of this core and particularly frequent in Sample 7A-2, 125-126 $\mathrm{cm}$. It was also observed in Sample 6A-5, 119-120 cm, but none was found in the other examined samples of this core. The Eocene/Oligocene boundary is therefore placed in Core $6 \mathrm{~A}$ between Sections 5 and 4 . The Chiasmolithus oamaruensis Zone was not recognized, but it could be present in the uncored interval between Cores 8 and 9 . A normal sequence of middle Eocene to uppermost lower Eocene nannoplankton assemblages was recovered from Core 9A down, but nannofossils there are poorly preserved, apparently because of diagenetic processes that affected the sediments. The presence of Discoaster sublodoensis in Core 12A, below the first Nannotetrina fulgens, indicates this nominal middle-lower Eocene zone.

Cool to temperate water conditions are suggested for the Pleistocene by the frequency of Coccolithus pelagicus and for the Pliocene and upper to middle Miocene by the general scarcity of discoasters. The fairly common sphenoliths in the lower/middle Miocene and Oligocene indicate more temperate conditions during this time. Discoasters are also more abundant in the lower Miocene. A great reduction in the frequency of chiasmoliths was observed in the Eocene and Oligocene of this site compared with the Cape Basin Site 360. This can indicate warmer water conditions connected with the lower latitude position of this site.

\section{SITE 363 \\ Walvis Ridge (lat $19^{\circ} 38.75$ 'S, long $09^{\circ} 02.80^{\prime} \mathrm{E}$, water depth $2248 \mathrm{~m}$ )}

Nannofossil assemblages ranging from upper Miocene to Lower Cretaceous were encountered at this site.

The stratigraphic distribution of the nannofossils and additional data on the abundance and preservation of the assemblages are shown in Tables 10 and 11 .
Breaks in the Miocene sedimentation are recorded in Core 1. Abundant, well to moderately preserved Oligocene coccoliths are present in a continuous sequence from Cores 2 to 8 . Diagnostic species of Sphenolithus and other markers allow us to recognize almost all Oligocene biozones. Unusual ooze intervals, predominantly composed of Braarudosphaera, correlate well with identical horizons in Site $362 \mathrm{~A}$ in the middle and lower Oligocene. The Eocene/Oligocene boundary based on the last occurrence of Discoaster saipanensis is placed in the upper part of Core 9 and is characterized by continuous sedimentation. In the fairly complete Eocene and Paleocene sequence the preservation is poorer in the Eocene because of recrystallization, becoming better in the Paleocene. The Cretaceous/Tertiary boundary is placed at Sample 18-2, 40 $\mathrm{cm}$. The lowermost Paleocene contains abundant Thoracosphaera and common Braarudosphaera which are typical for Danian sediments. Cruciplacolithus tenuis, however, is present until the Cretaceous boundary; thus the oldest known Tertiary nannofossil associations are not present at this site.

Sample $18-2,41 \mathrm{~cm}$ to Core 25 represent a continuous sequence of Upper Cretaceous nannofossil zones from upper Maestrichtian to Santonian/Coniacian. Preservation is good in the upper Maestrichtian Micula mura Zone, moderate to good in Cores 20 to 25 with some scattered only poorly preserved samples. Core 25 is referred to the Santonian/Coniacian Marthasterites furcatus Zone.

Below this core nannofloras become sparse and generally poorly preserved. Braarudosphaera and Nannoconus of the truitti group are present in this part of the sequence. An upper Albian age is inferred for Cores 26 to 34 based on the presence of Eiffellithus turriseiffeli and the absence of younger markers. The only specimen of Micula staurophora found in Sample $26-2,94-95 \mathrm{~cm}$, suggesting a Turonian age for this sample, is more likely the result of contamination from above. The Cenomanian marker Lithraphidites alatus was not observed at this site. It could, however, be absent for ecological reasons and the possibility for a younger age of the upper part of this interval cannot entirely be excluded. Nevertheless, an Albian age seems more probable, leaving a gap in the sedimentary sequence corresponding to the Cenomanian and Turonian.

Cores 35 to 38 , situated below the first occurrence of Eiffellithus turriseiffeli and above that of Prediscosphaera cretacea, are referred to the lower/middle Albian Prediscosphaera cretacea Zone.

Core 39 no longer contains Prediscosphaera cretacea and, based on some questionable specimens of Parhabdolithus angustus, is tentatively referred to the nominal zone of upper Aptian/lower Albian age.

Core 40 only contains Watznaueria and Parhabdolithus embergeri and cannot, therefore, be dated.

From a paleoecologic point of view, rather warmwater conditions are assumed for the Paleogene. This is based on the more abundant sphenoliths and more scarce chiasmoliths when compared with the Cape Basin Sites 360 and 361. The presence of Braarudo- 
TABLE 8B

Distribution of Upper Miocene-Upper Oligocene Calcareous Nannofossils at Site 362

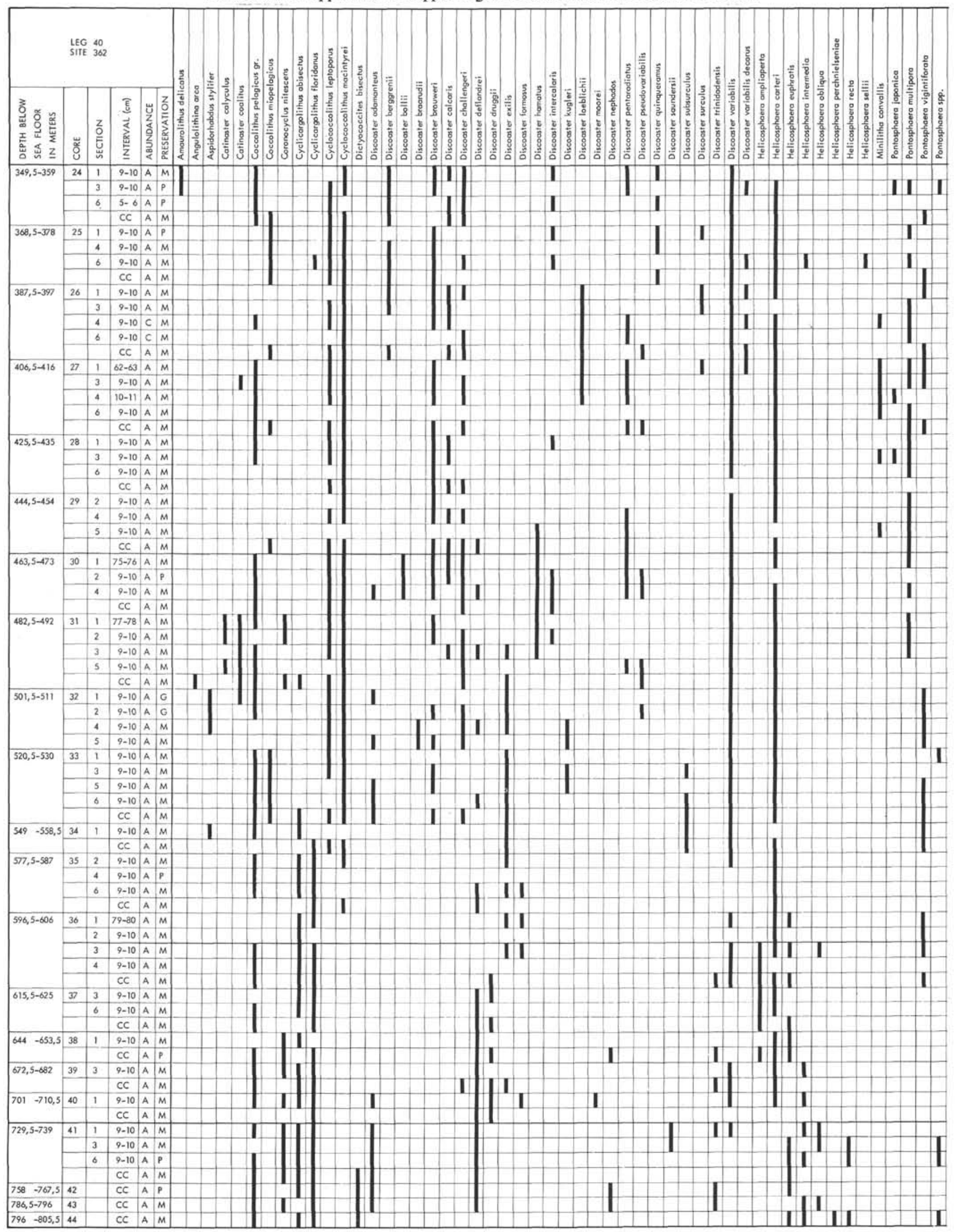


TABLE 8B - Continued

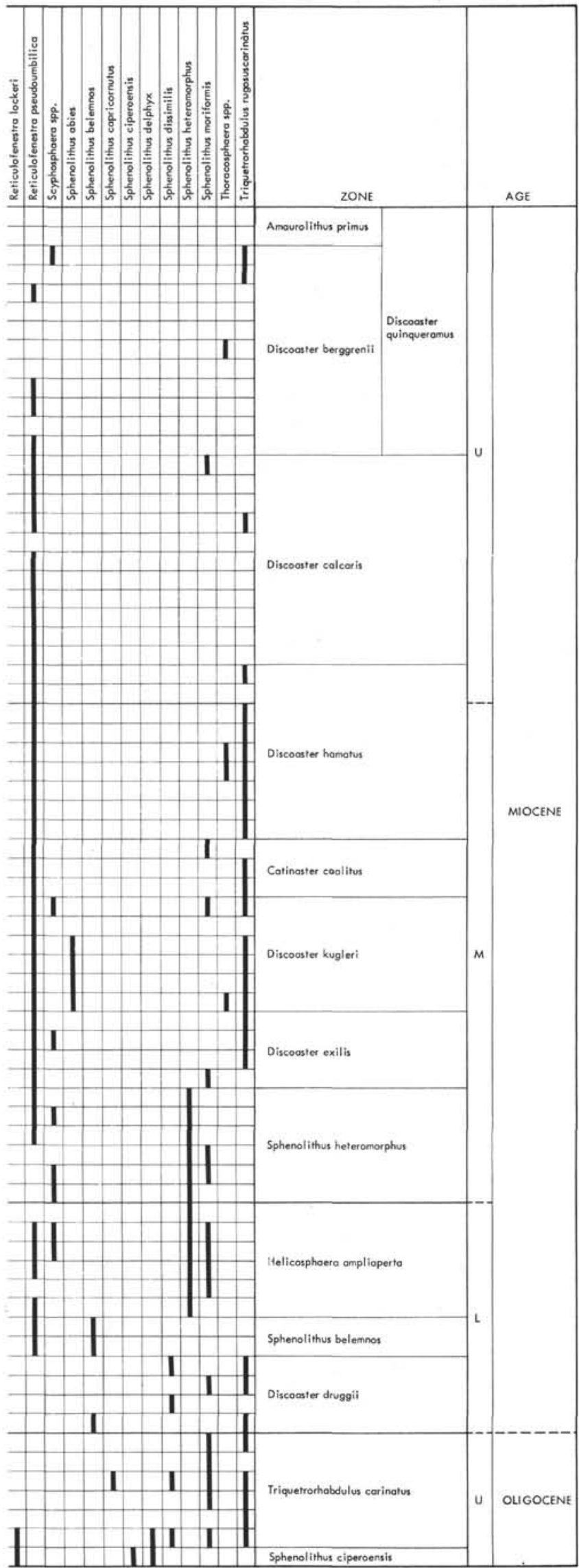

sphaera and the abundance of Thoracosphaera in the lowermost Paleocene could indicate neritic or upper bathyal conditions. Warm-water conditions are also suggested for the upper Maestrichtian on the presence of Micula mura.

\section{SITE 364}

\section{Angola Basin (lat $11^{\circ} 34.32^{\prime} \mathrm{S}$, long $11^{\circ} 58.30^{\prime} \mathrm{E}$, water depth $2248 \mathrm{~m}$ )}

Coccolith assemblages ranging from Holocene to Lower Cretaceous occur in the section of this discontinuously cored site. The stratigraphic distribution of the calcareous nannofossils and the abundance and preservation of the assemblages are shown in Tables 12-14.

Good to moderately preserved Quaternary assemblages with abundant Helicosphaera carteri and Gephyrocapsa oceanica are present in Core 1 (7.5-17 m). The upper part of Core 1 contains many reworked Upper Cretaceous and Paleogene forms. A peculiar association composed almost exclusively of Helicosphaera carteri is present in the core catcher of Core 1. This species is characteristic of tropical to subtropical areas.

Samples from Core $2(34-46.5 \mathrm{~m})$ are barren except for Sample 364-2-2, 9-10 cm and the core catcher which contain a poorly preserved upper Pliocene assemblage of the Discoaster brouweri Zone. Nannofloras are common to rare and contain reworked Upper Cretaceous and Cenozoic specimens.

Moderately well preserved lower Pliocene assemblages occur through Core $3(64.5-74 \mathrm{~m})$. The great abundance of discoasters, such as $D$. brouweri and $D$. pentaradiatus, suggests warm-water conditions. Reworked specimens are common in Sample 3-6, 9-10 $\mathrm{cm}$ and in the core catcher.

Core $4(102.5-112 \mathrm{~m})$. contains upper Miocene coccolith assemblages. Preservation is moderate to good. Discoasters are abundant and sphenoliths are common. Based on the presence of the name-giving species, Sample 4-6, 9-10 cm and the core catcher are referred to the Discoaster hamatus Zone.

Coccoliths are very rare in Core 5 (150-159.5 m) except for Sample 5-4, 9-10 cm that contains an upper lower Miocene assemblage. The concurrence of rare Helicosphaera ampliaperta, abundant Sphenolithus heteromorphus, common Cyclococcolithus macintyrei, and Discoaster deflandrei allows the assignment of this sample to the upper part of the Helicosphaera ampliaperta Zone.

Samples of Cores $6(197.5-207 \mathrm{~m})$ and 7 (245-254.5 m) are barren of calcareous nannofossils except for Sample 7, CC that contains a moderately preserved middle Eocene assemblage of the Nannotetrina fulgens Zone.

The lower Eocene Discoaster sublodoensis, Discoaster lodoensis, and Tribrachiatus orthostylus zones are condensed in Core $8(283-295.5 \mathrm{~m})$. Coccoliths are abundant, but have only a moderate to poor preservation. Only the core catcher of Core 8 contains abundant Zygrhablithus bijugatus, a shallow water indicator which is frequent at Site 362 . 
TABLE 9

Distribution of Middle Oligocene-Middle Eocene Calcareous Nannofossils at Site 362A

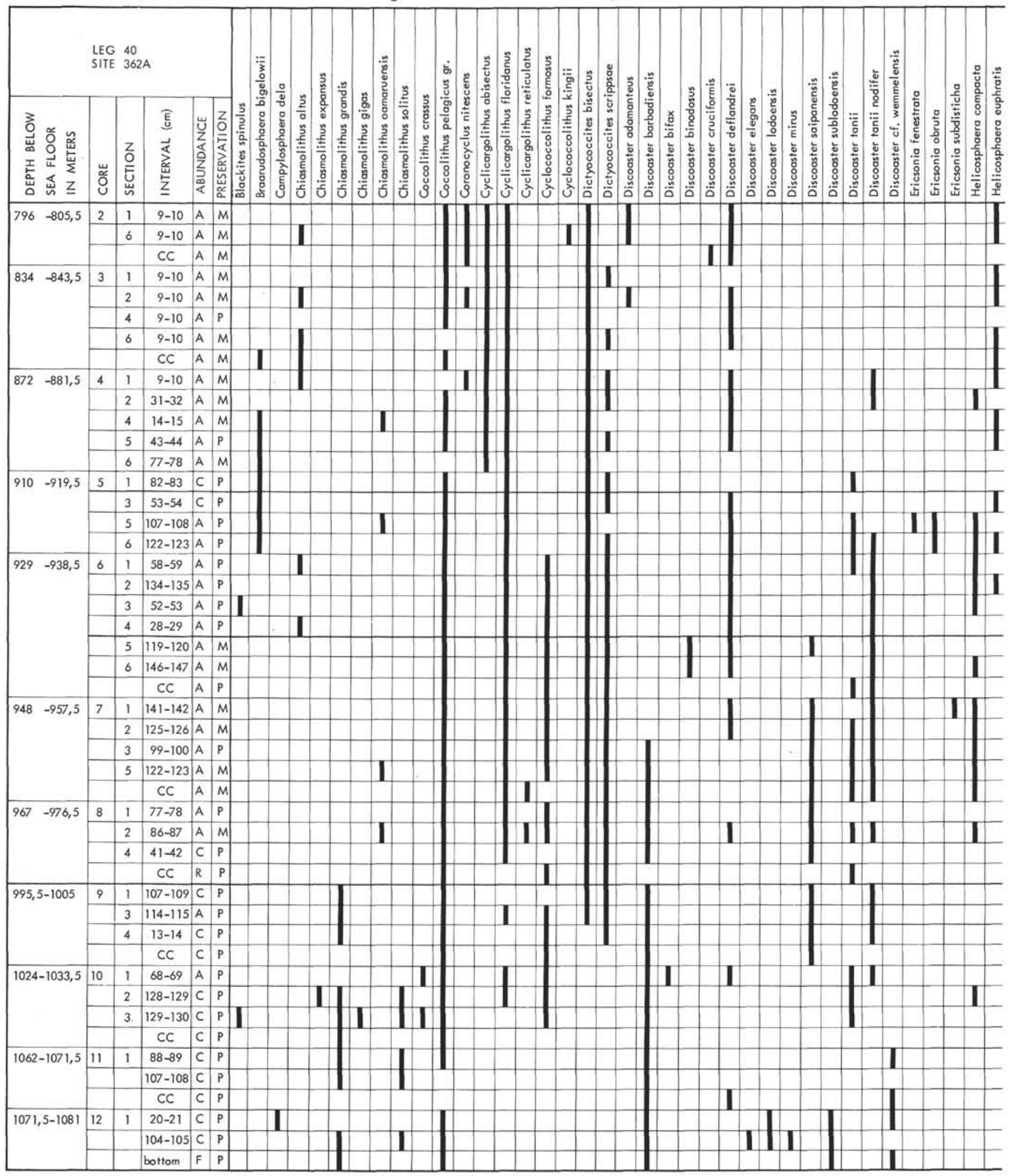

Lowermost Eocene and Paleocene assemblages are present in Cores 9 and $10(321-359 \mathrm{~m})$. The great abundance of discoasters and the poor preservation of placoliths suggest dissolution effects in this interval.
The catcher of Core 9 contains nannofossils of the lower Paleocene Cruciplacolithus tenuis Zone.

Cores 11 and $12(359-378 \mathrm{~m})$ contain abundant but poorly preserved coccolith assemblages, which show 
TABLE 9 - Continued

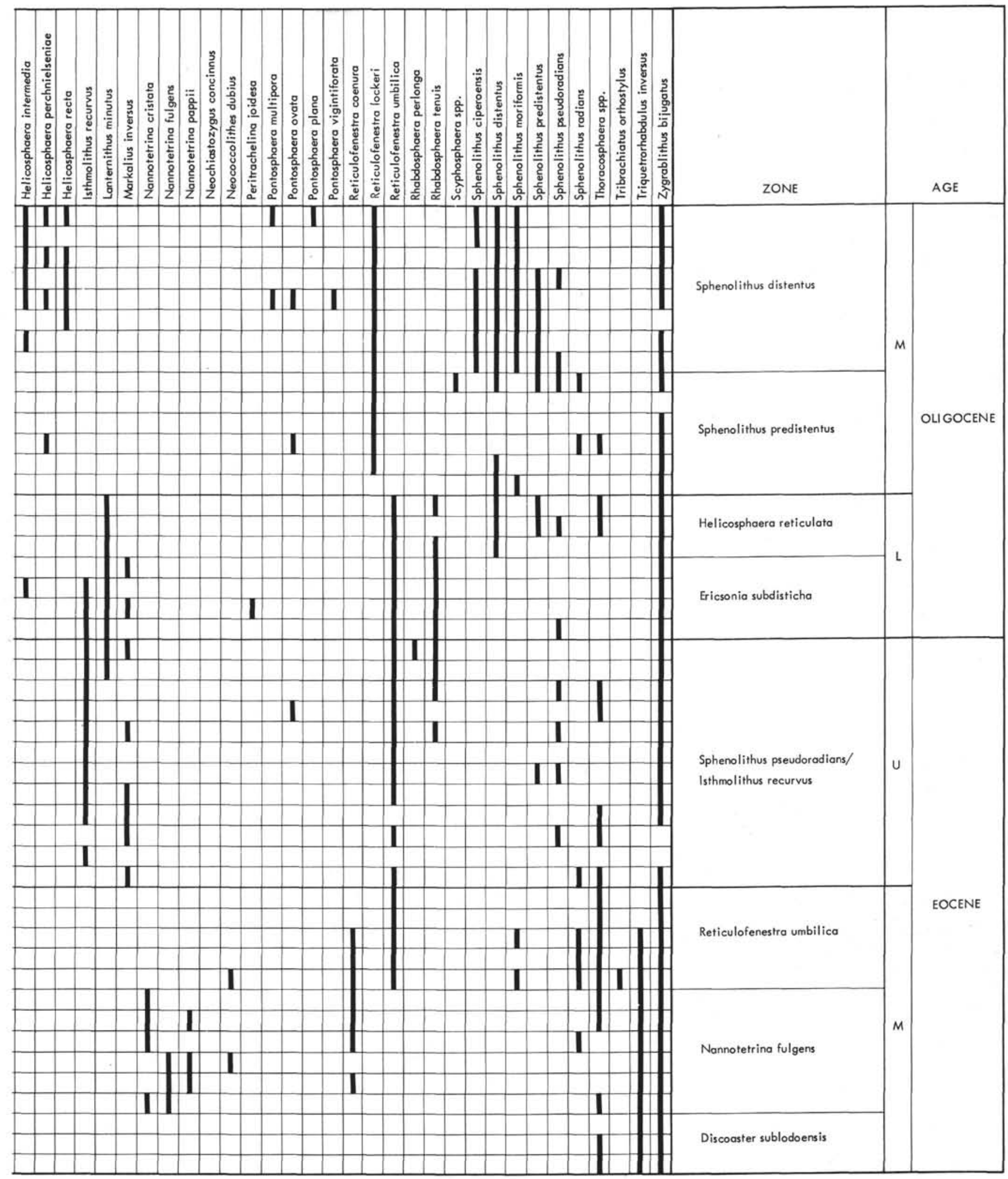

strong signs of dissolution. The species present suggest Upper Cretaceous Maestrichtian. Because of the absence of diagnostic species, an exact biostratigraphic assignment is difficult. However, the absence of Micula mura and Lithraphidites quadratus might suggest an Arkhangelskiella cymbiformis Zone age.

Cores 13 and $14(397-435 \mathrm{~m})$ are referred to the upper Campanian to lower Maestrichtian Tetralithus trifidus 
TABLE 10

Distribution of Miocene-Paleocene Calcareous Nannofossils at Site 363

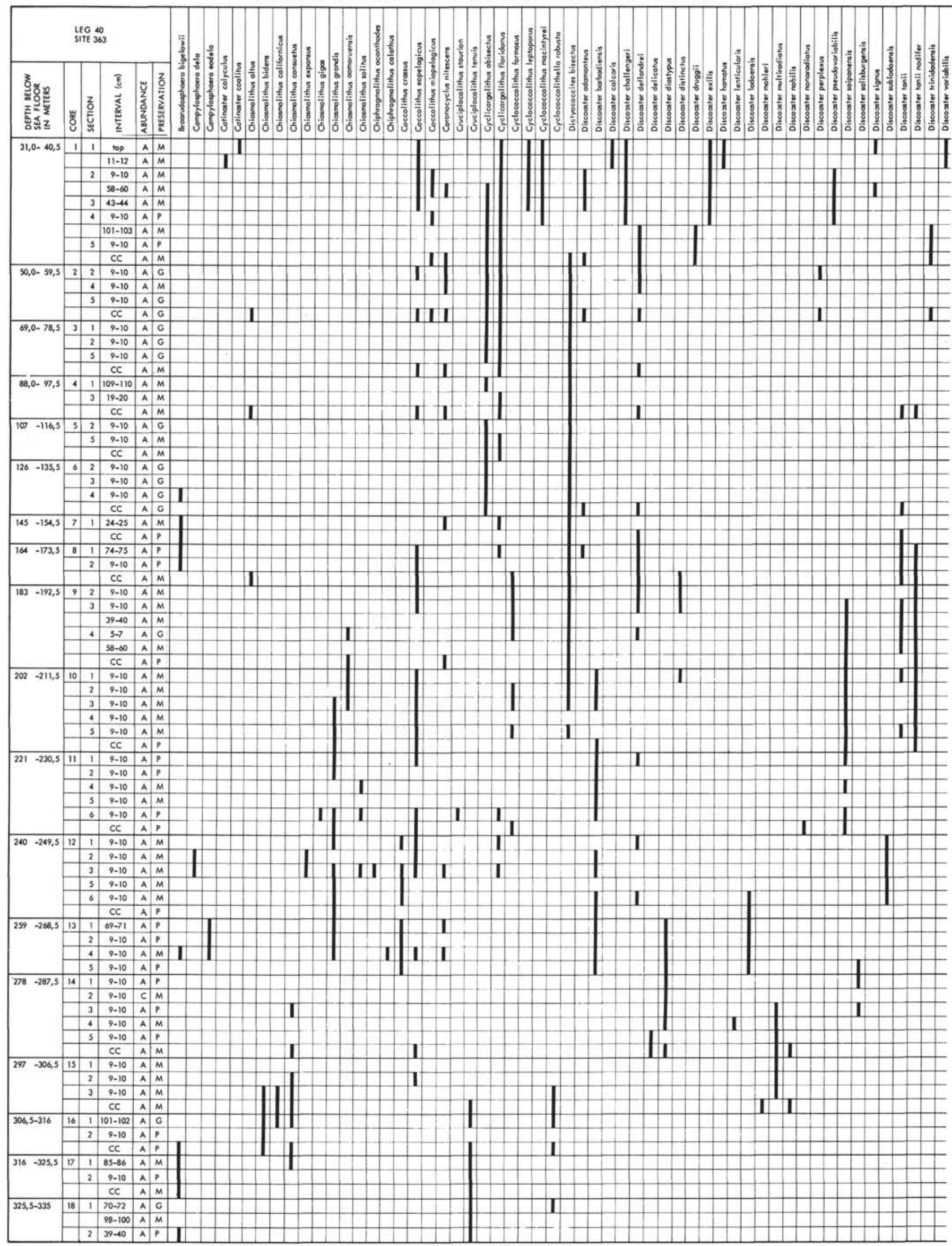




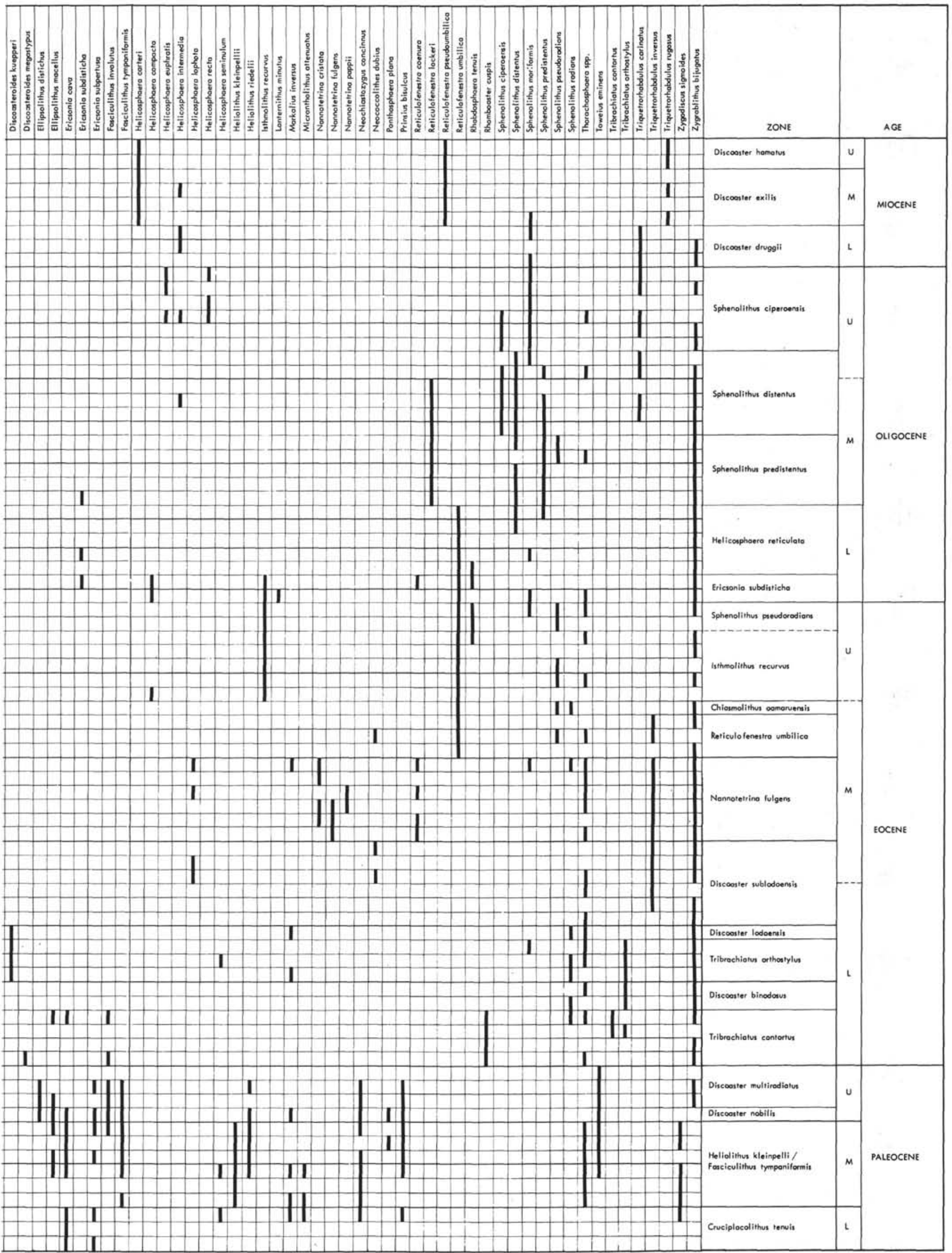


TABLE 11

Distribution of Maestrichtian-Aptian Calcareous Nannofossils at Site 363

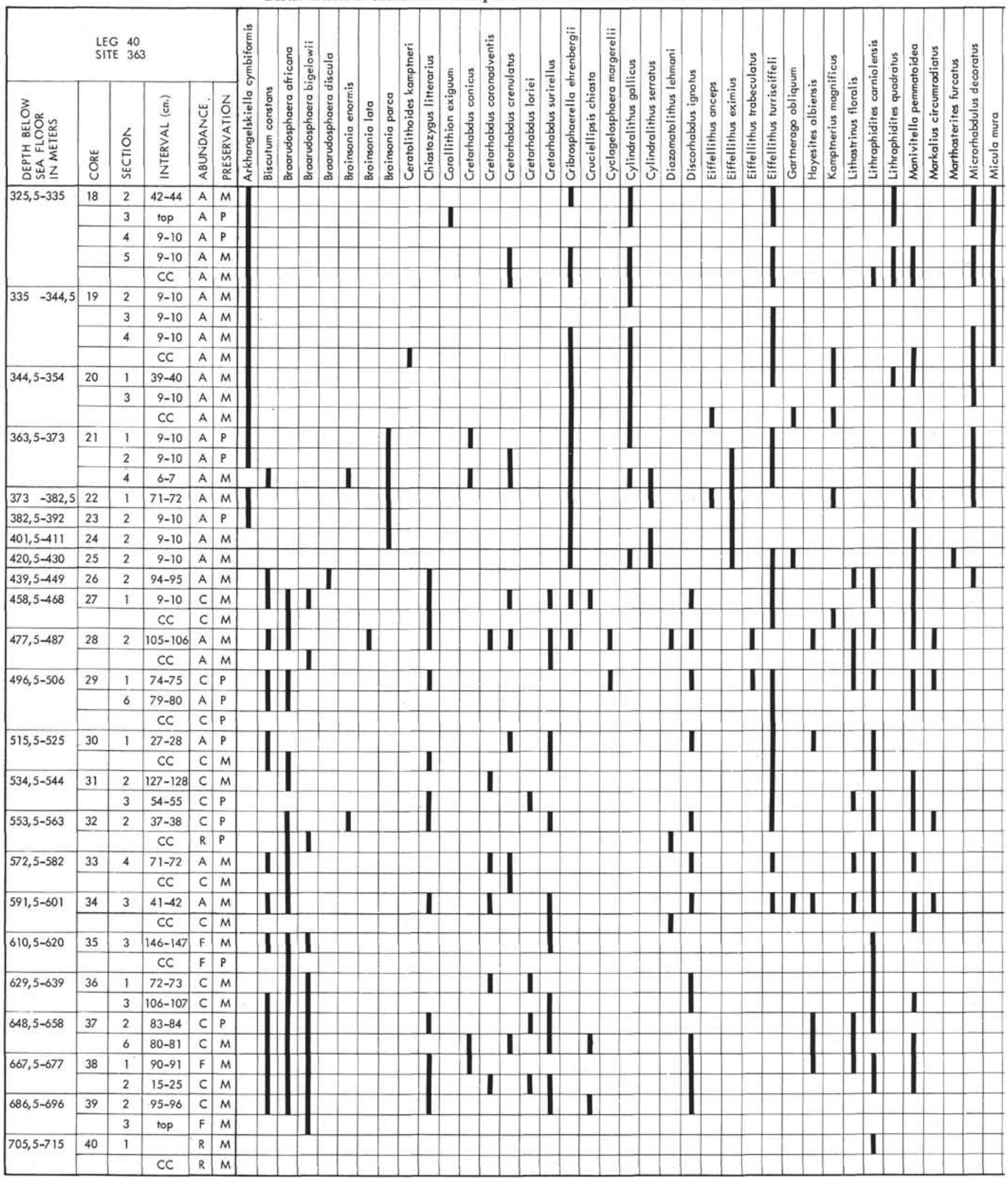

Zone except for Sample 364-13-1, 40-41 cm that is assigned to the lower Maestrichtian Arkhangelskiella cymbiformis Zone based on the absence of Tetralithus trifidus.

Cores 15 and $16(463.5-511 \mathrm{~m})$ yield assemblages that include Broinsonia parca and Eiffellithus eximius typical of the Campanian Eiffellithus eximius Zone. Nannofossils are generally abundant, their preservation is moderate to poor.

Cores 17 to 23, Sections 1-3 (530-648 m) recovered assemblages of the Marthasterites furcatus Zone which is considered Coniacian-Santonian. Based on the 


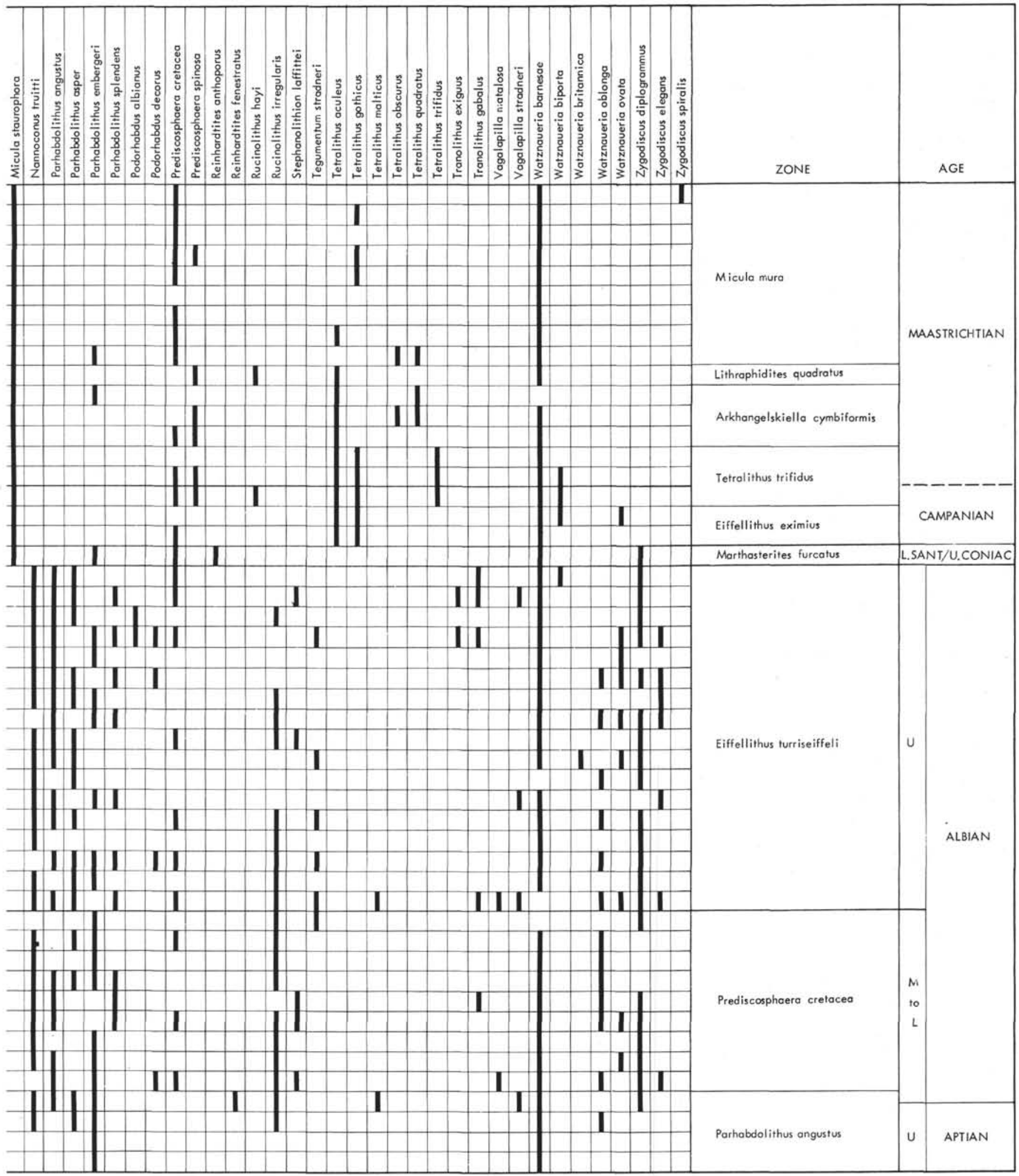

absence of Marthasterites furcatus, Section 4A, 7-8 cm of Core 23 is assigned to the lower Coniacian-upper Turonian Micula staurophora Zone. The core catcher of Core 23 contains only rare nannofossils with Eiffellithus turriseiffeli and Watznaueria barnesae that do not allow for detailed biostratigraphic dating.
In Cores 24 to $33(672.5-853 \mathrm{~m})$ richer nannofloras occur at different levels that could belong to the upper Albian Eiffellithus turriseiffeli Zone. Nannofossils are generally abundant, but are only moderately to poorly preserved. Overgrowth and fragmentation have affected some assemblages. The absence of 
TABLE 12A

Distribution of Pleistocene-Paleocene Calcareous Nannofossils at Site 364

\begin{tabular}{|c|c|c|c|c|c|c|c|c|c|c|c|c|c|c|c|c|c|c|c|c|c|c|c|c|c|c|c|c|c|c|c|c|}
\hline \multicolumn{7}{|c|}{$\begin{array}{l}\text { LEG } 40 \\
\text { SITE } 364\end{array}$} & & & \multirow[b]{2}{*}{ 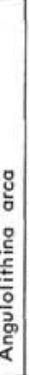 } & \multirow{2}{*}{\multicolumn{2}{|c|}{ 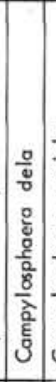 }} & & & & & & & & & & & & & & & & & & & s. & & \\
\hline 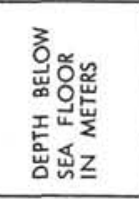 & 茲 & 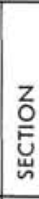 & & 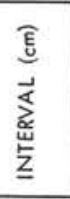 & 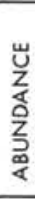 & 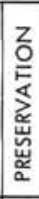 & 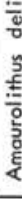 & & & & & 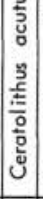 & 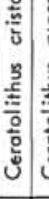 & 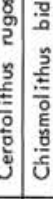 & 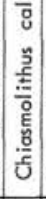 & 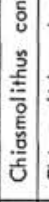 & 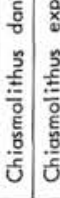 & 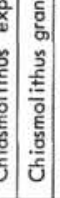 & 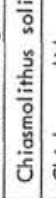 & 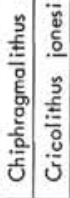 & 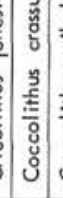 & 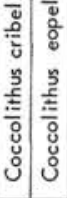 & 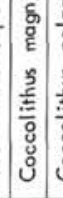 & 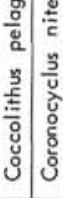 & 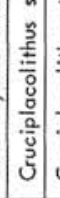 & 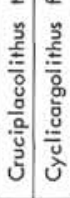 & 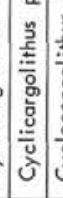 & & & 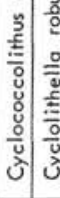 & & 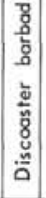 \\
\hline $7,5-17$ & 1 & 1 & & $13-14$ & $\mathrm{~F}$ & M & & & & & & & & & & & & & & & & & & I & & & & & & & & \\
\hline & & 2 & & $9-10$ & A & M & & & & & & & & & & & & & & & & & & t & & & & & & & & \\
\hline & & 3 & & $9-10$ & c & M & & & & & & & 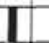 & & & & & & & & & & & & & & & & & & & \\
\hline & & 4 & & $9-10$ & A & M & & & & & & & & & & & & & & & & & & t & & & & & & & & \\
\hline & & 5 & & $9-10$ & c & $M$ & & & & & & & & & & & & & & & & & & & . & & & & & & & \\
\hline & & 6 & & $9-10$ & A & M & & & & & & & & & & & & & & & & & & & & & & & & & & \\
\hline & & & & $\mathrm{CC}$ & A & G & & & & & & & & & & & & & & & & & & & & & & & & & & \\
\hline $36-45,5$ & 2 & 2 & & $9-10$ & $R$ & $P$ & & & & & & & & & & & & & & & & & & & & & & & & & & \\
\hline & & & & $\mathrm{CC}$ & c & $M$ & & & & & & & & & & & & & & & & & & & & & & & & & & \\
\hline $64,5-74$ & 3 & 1 & & $33-34$ & A & G & & & & & & & & & & & & & & & & & & & & & & & & & & \\
\hline & & 2 & & $9-10$ & A & G & & & & & & & & & & & & & & & & & & & 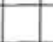 & & & & & & & \\
\hline & & 3 & & $9-10$ & A & G & & & & & & & & & & & & & & & & & & & & & & & & & & \\
\hline & & 4 & & $9-10$ & A & G & & & & & & & & & & & & & & & & & & I & & & & & & & & \\
\hline & & 5 & & $9-10$ & c & G & & & & & & & & & & & & & & & & & & & & & & & & & & \\
\hline & & 6 & & $9-10$ & c & $G$ & & & & & & & & & & & & & & & & & & | & & & & & & & & \\
\hline & & & & $\mathrm{CC}$ & A & G & & & & & & & & & & & & & & & & & & & & & & & & & & \\
\hline $102,5-112$ & 4 & 2 & & $9-10$ & c & $M$ & & & & & & & & & & & & & & & & & & & & & & & & & & \\
\hline & & 3 & & $9-10$ & A & $M$ & & & & & & & & & & & & & & & & & & & & & & & & & & \\
\hline & & 4 & & $9-10$ & c & M & & & & & & & & & & & & & & & & & & & & & & & & & & \\
\hline & & 5 & & $9-10$ & c & M & & & & & & & & & & & & & & & & & & & & & & & & & & \\
\hline & & 6 & & $9-10$ & A & M & & & & & & & & & & & & & & & & & & & & & & & & & & \\
\hline & & & & $\mathrm{CC}$ & A & M & & & & & & & & & & & & & & & & & & & & & & & & & & \\
\hline $150-159,5$ & 5 & 3 & & $9-10$ & c & $M$ & & & & & & & & & & & & & & & & & & I & & & & & & & & \\
\hline & & & & $\mathrm{Cc}$ & $R$ & $p$ & & & & & & & & & & & & & & & & & & & & & & & & & & \\
\hline $197,5-207$ & 6 & 1 & & $9-10$ & & & & & & & & & & & & & & & & & & & & & & & & & & & & \\
\hline & & & & $\mathrm{CC}$ & & & & & & & & & & & & & & & & & & & & & & & & & & & & \\
\hline $245 \quad-254,5$ & 7 & 1 & & $9-10$ & & & & & & & & & & & & & & & & & & & & & & & & & & & & \\
\hline & & & & $\mathrm{CC}$ & A & M & & & & & & & & & & & & & & & & & & & I & & & & & & & \\
\hline $283-292,5$ & 8 & 1 & & $9-10$ & A & M & & & & & & & & & & & & & & & & & & & & & | & & & & & \\
\hline & & 2 & & $9-10$ & A & $M$ & & & & & & & & & & & & & & & & & & & & & & & & & & \\
\hline & & 3 & & $9-10$ & A & M & & & & & & & & & & & & & & & & & & & I & & & & & & & \\
\hline & & 4 & & $9-10$ & A & $M$ & & & & & & & & & & & & & & & & & & & & & & & & & & \\
\hline & & 5 & & $9-10$ & A & M & & & & & cf & & & & & & & & & & & & & & & & & & & & & \\
\hline & & 6 & & $9-10$ & c & M & & & & & of & & & & & & & & & & & & & & & & & & & & & \\
\hline & & & & $\mathrm{CC}$ & A & $M$ & & & & & of & & & & & & & & & & & & & & & & & & & & & \\
\hline $321 \quad-330,5$ & 9 & 1 & & $17-18$ & c & M & & & & & & & & & & & & & & & & & & & & & & & & & & \\
\hline & & 2 & & $9-10$ & A & $M$ & & & & & & & & & & & & & & & & & & & & & & & & & & \\
\hline & & 3 & & $9-10$ & A & $M$ & & & & & & & & & & & & & & & & & & & & & & & & & & \\
\hline & & 4 & & $9-10$ & A & M & & & & & & & & & & & & & & & & & & & & & & & & & & \\
\hline & & & & $C C$ & A & M & & & & & & & & & & & & & & & & & & & & & & & & & & \\
\hline $349,5-359$ & 10 & 1 & & $39-40$ & A & $P$ & & & & & & & & & & & & & & & & & & & & & & & & & & \\
\hline & & 2 & & $9-10$ & A & $p$ & & & & & & & & & & & & & & & & & & & & & & & & & & \\
\hline & & 3 & & $9-10$ & A & $P$ & & & & & & & & & & & of & & & & & & & & & & & & & & & \\
\hline & & 4 & & $9-10$ & c & $P$ & & & & & & & & & & & & & & & & & & & & & & & & & & \\
\hline & & 5 & & $9-10$ & A & $p$ & & & & & & & & & & & & & & & & & & & & & & & & & & \\
\hline & & 6 & & $9-10$ & $R$ & $p$ & & & & & & & & & & & & & & & & & & & & & & & & & & \\
\hline & & & & CC & & & & & & & & & & & & & & & & & & & & & & & & & & & & \\
\hline
\end{tabular}




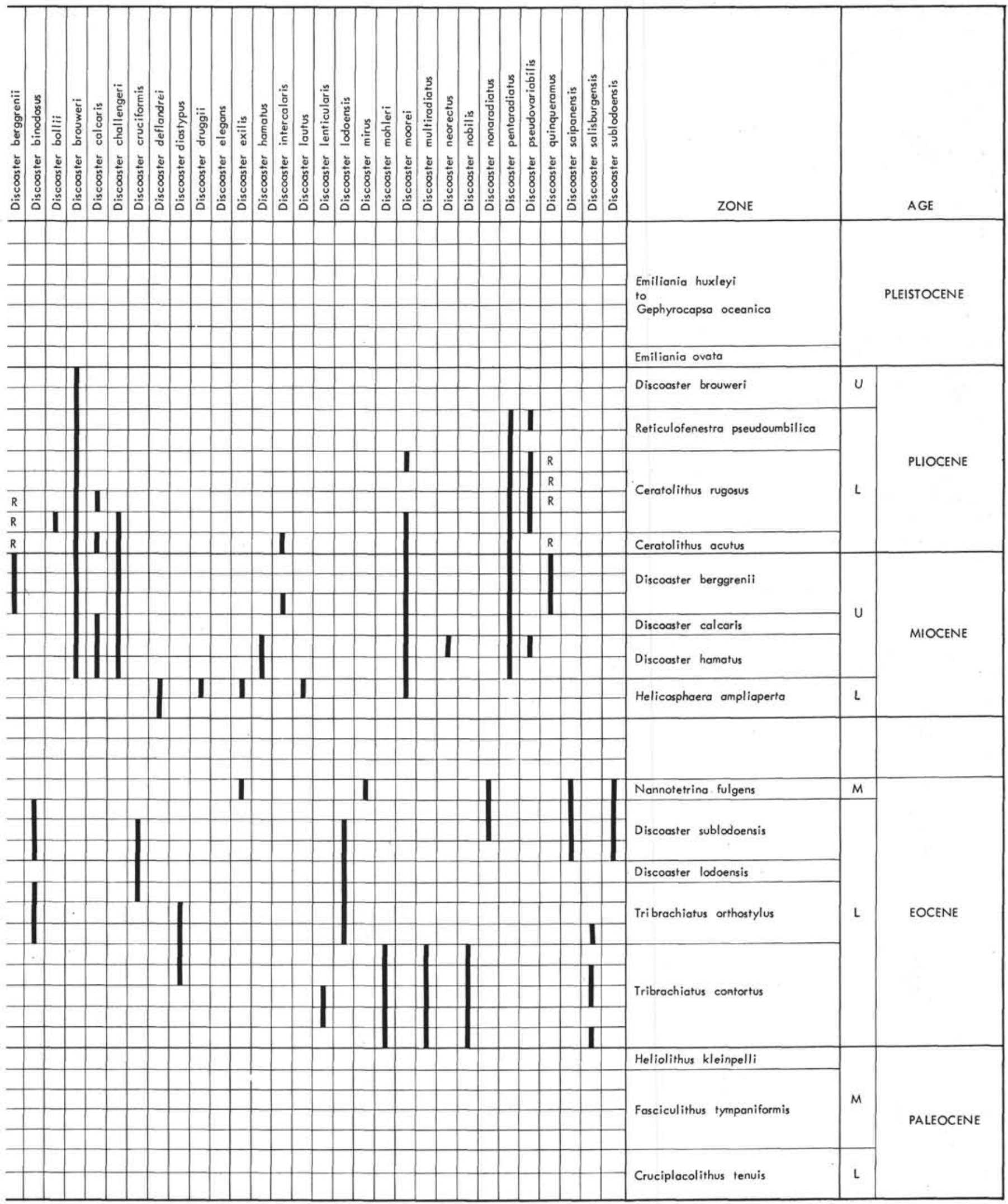


TABLE 12B

Distribution of Pleistocene-Paleocene Calcareous Nannofossils at Site 364

\begin{tabular}{|c|c|c|c|c|c|c|c|c|c|c|c|c|c|c|c|c|c|c|c|c|c|c|c|c|c|c|c|c|c|c|c|c|c|c|c|c|}
\hline \multicolumn{6}{|c|}{$\begin{array}{ll}\text { LEG } & 40 \\
\text { SITE } & 364\end{array}$} & \multirow[b]{2}{*}{ ב } & \multirow{2}{*}{ 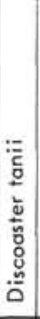 } & & & & 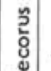 & $=$ & aे & & & & & & & & $\frac{n}{E}$ & & & $\stackrel{0}{t}$ & & & & & & & & & & & & \\
\hline 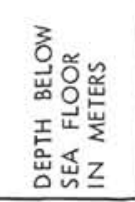 & $\begin{array}{l}\text { 山ू } \\
\text { О }\end{array}$ & $\begin{array}{l}z \\
O \\
\text { z } \\
\text { w }\end{array}$ & $\begin{array}{l}\text { हु } \\
\vec{s} \\
\vec{z} \\
\text { 岁 } \\
\underline{z}\end{array}$ & 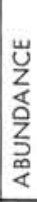 & 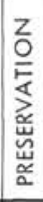 & & & & 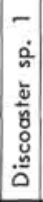 & 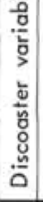 & 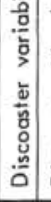 & 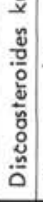 & 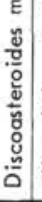 & 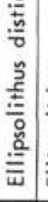 & 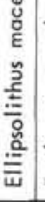 & 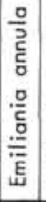 & 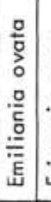 & 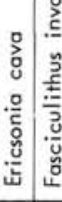 & 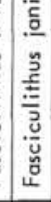 & 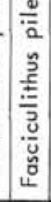 & 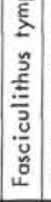 & \begin{tabular}{|c|} 
\\
0 \\
0 \\
0 \\
0 \\
0 \\
0 \\
0 \\
-0 \\
0 \\
0 \\
0
\end{tabular} & 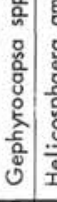 & 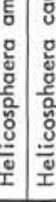 & 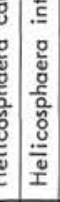 & 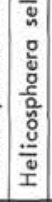 & 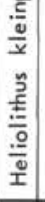 & 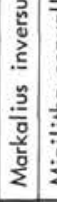 & 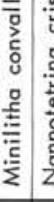 & 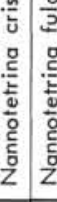 & 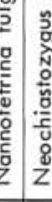 & 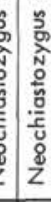 & 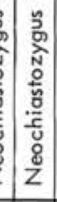 & 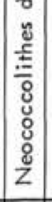 & 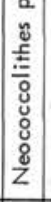 & 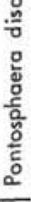 \\
\hline $7,5-17$ & 1 & 1 & $13-14$ & $\mathrm{~F}$ & M & & & & & & & & & & & & & & & & & & & & & & & & & & & & & & & \\
\hline & & 2 & $9-10$ & A & M & & & & & & & & & & & & & & & & & & & & & & & & & & & & & & & \\
\hline & & 3 & $9-10$ & C & $M$ & & & & & & & & & & & & & & & & & & & & & & & & & & & & & & & \\
\hline & & 4 & $9-10$ & A & $M$ & & & & & & & & & & & & & & & & & & & & & & & & & & & & & & & \\
\hline & & 5 & $9-10$ & C & $M$ & & & & & & & & & & & & & & & & & & & & & & & & & & & & & & & \\
\hline & & 6 & $9-10$ & A & M & & & & & & & & & & & & & & & & & & & & & & & & & & & & & & & \\
\hline & & $\mathrm{CC}$ & & A & G & & & & & & & & & & & & & & & & & & & & & & & & & & & & & & & \\
\hline $36-45,5$ & 2 & 2 & $9-10$ & $\mathrm{R}$ & $P$ & & & & & & & & & & & & & & & & & & & & & & & & & & & & & & & \\
\hline & & $\mathrm{CC}$ & & C & $M$ & & & & & & & & & & & & & & & & & & & & & & & & & & & & & & & \\
\hline $64,5-74$ & 3 & 1 & $33-34$ & A & G & & & & & & & & & & & & & & & & & & & & & & & & & & & & & & & \\
\hline & & 2 & $9-10$ & A & G & & & & & & & & & & & & & & & & & & & & & & & & & & & & & & & \\
\hline & & 3 & $9-10$ & A & G & & & & & & & & & & & & & & & & & & & & & & & & & & & & & & & \\
\hline & & 4 & $9-10$ & A & G & & & & & & & & & & & & & & & & & & & & & & & & & & & & & & & \\
\hline & & 5 & $9-10$ & C & G & & & & & & & & & & & & & & & & & & & & & & & & & & & & & & & \\
\hline & & 6 & $9-10$ & C & G & & & & & & & & & & & & & & & & & & & & & & & & & & & & & & & \\
\hline & & $\mathrm{CC}$ & & A & G & & & & & & & & & & & & & & & & & & & & & & & & & & & & & & & \\
\hline $102,5-112$ & 4 & 2 & $9-10$ & C & $M$ & & & & & & & & & & & & & & & & & & & & & & & & & & & & & & & \\
\hline & & 3 & $9-10$ & A & $M$ & & & & & & & & & & & & & & & & & & & & & & & & & & & & & & & \\
\hline & & 4 & $9-10$ & C & $M$ & & & & & & & & & & & & & & & & & & & & & & & & & & & & & & & \\
\hline & & 5 & $9-10$ & C & $M$ & & & & & & & & & & & & & & & & & & & & & & & & & & & & & & & \\
\hline & & 6 & $9-10$ & A & M & & & & & & & & & & & & & & & & & & & & & & & & & & & & & & & \\
\hline & & $\mathrm{CC}$ & & A & $M$ & & & & & & & & & & & & & & & & & & & & & & & & & & & & & & & \\
\hline $150-159,5$ & 5 & 3 & $9-10$ & C & $M$ & & & & & & & & & & & & & & & & & & & & & & & & & & & & & & & \\
\hline . & & $\mathrm{CC}$ & & $R$ & $P$ & & & & & & & & & & & & & & & & & & & & & & & & & & & & & & & \\
\hline $197,5-207$ & 6 & 1 & $9-10$ & & & & & & & & & & & & & & & & & & & & & & & & & & & & & & & & & \\
\hline & & $\mathrm{CC}$ & & & & & & & & & & & & & & & & & & & & & & & & & & & & & & & & & & \\
\hline $245-254,5$ & 7 & 1 & $9-10$ & & & & & & & & & & & & & & & & & & & & & & & & & & & & & & & & & \\
\hline & & $\mathrm{CC}$ & & A & $M$ & & & & & & & & & & & & & & & & & & & & & & & & & & & & & & & \\
\hline $283-292,5$ & 8 & 1 & $9-10$ & A & $M$ & & & & & & & & & & & & & & & & & & & & & & & & & & & & & & & \\
\hline & & 2 & $9-10$ & A & M & & & & & & & & & & & & & & & & & & & & & & & & & & & & & & & \\
\hline & & 3 & $9-10$ & A & $M$ & & & & & & & & & & & & & & & & & & & & & & & & & & & & & & & \\
\hline & & 4 & $9-10$ & A & $M$ & & & & & & & & & & & & & & & & & & & & & & & & & & & & & & & \\
\hline & & 5 & $9-10$ & A & M & & & & & & & & & & & & & & & & & & & & & & & & & & & & & & & \\
\hline & & 6 & $9-10$ & C & $M$ & & & & & & & & & & & & & & & & & & & & & & & & & & & & & & & \\
\hline & & $\mathrm{CC}$ & & A & $M$ & & & & & & & & & & & & & & & & & & & & & & & & & & & & & & & \\
\hline $321-330,5$ & 9 & 1 & $17-18$ & C & $M$ & & & & & & & & & & & & & & & & & & & & & & & & & & & & & & & \\
\hline & & 2. & $9-10$ & A & M & & & & & & & & & & & & & & & & & & & & & & & & & & & & & & & \\
\hline & & 3 & $9-10$ & A & M & & & & & & & & & & & & & & & & & & & & & & & & & & & & & & & \\
\hline & & 4 & $9-10$ & A & M & & & & & & & & & & & & & & & & & & & & & & & & & & & & & & & \\
\hline & & $\mathrm{CC}$ & & A & M & & & & & & & & & & & & & & & & & & & & & & & & & & & & & & & \\
\hline $349,5-359$ & 10 & 1 & $39-40$ & A & $P$ & & & & & & & & & & & & & & & & & & & & & & & & & & & & & & & \\
\hline & & 2 & $9-10$ & A & $P$ & & & & & & & & & & & & & & & & & & & & & & & & & & & & & & & \\
\hline & & 3 & $9-10$ & A & $P$ & & & & & & & & & & & & & & & & & & & & & & & & & & & & & & & \\
\hline & & 4 & $9-10$ & C & $P$ & & & & & & & & & & & & & & & & & & & & & & & & & & & & & & & \\
\hline & & 5 & $9-10$ & A & $\mathrm{P}$ & & & & & & & & & & & & & & & & & & & & & & & & & & & & & & & \\
\hline & & 6 & $9-10$ & $R$ & $P$ & & & & & & & & & & & & & & & & & & & & & & & & & & & & & & & \\
\hline & & $C C$ & & A & $P$ & & & & & & & & & & & & & & & & & & & & & & & & & & & & & & & \\
\hline
\end{tabular}


TABLE 12B - Continued

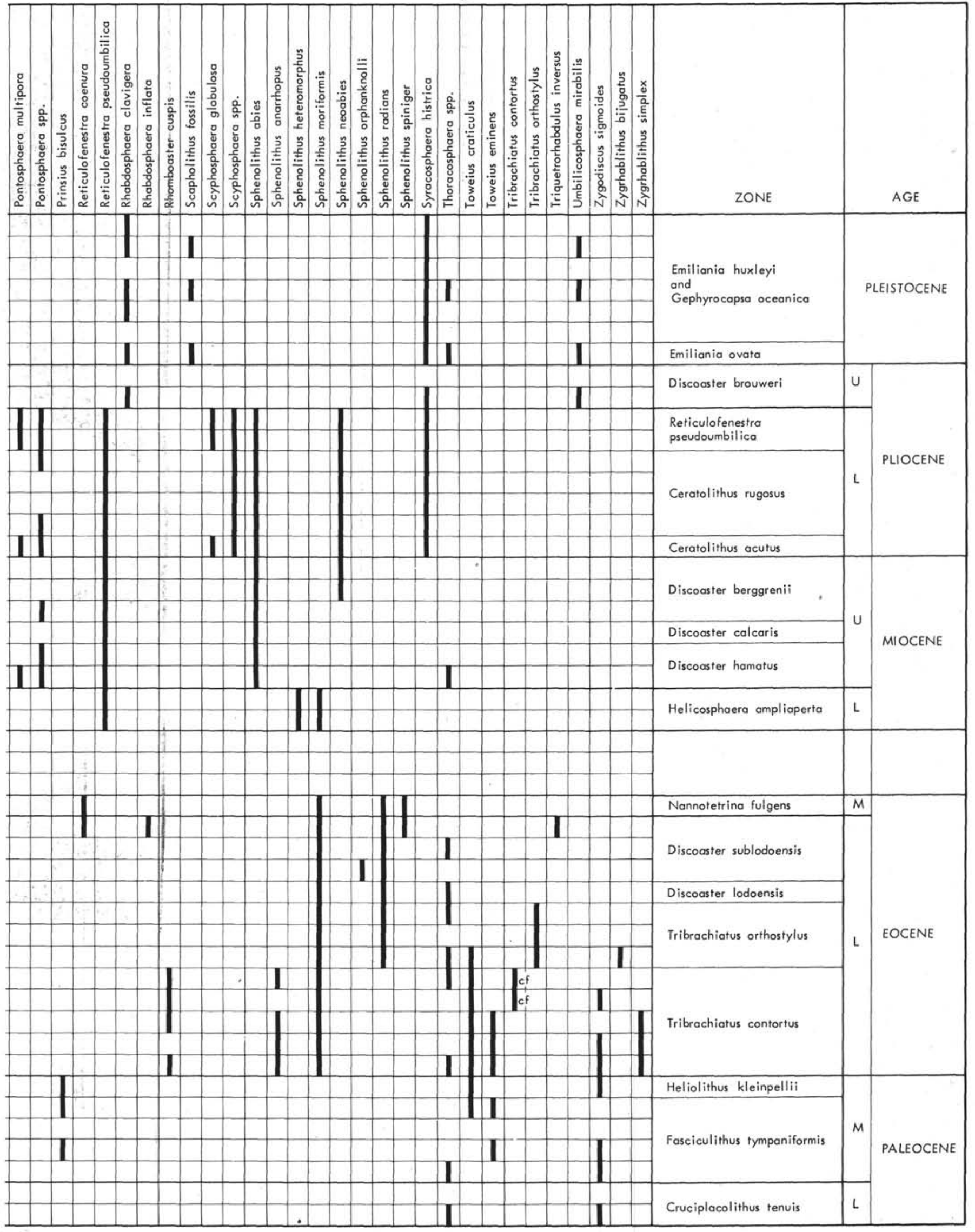


TABLE 13

Distribution of Maestrichtian-Coniacian Calcareous Nannofossils at Site 364

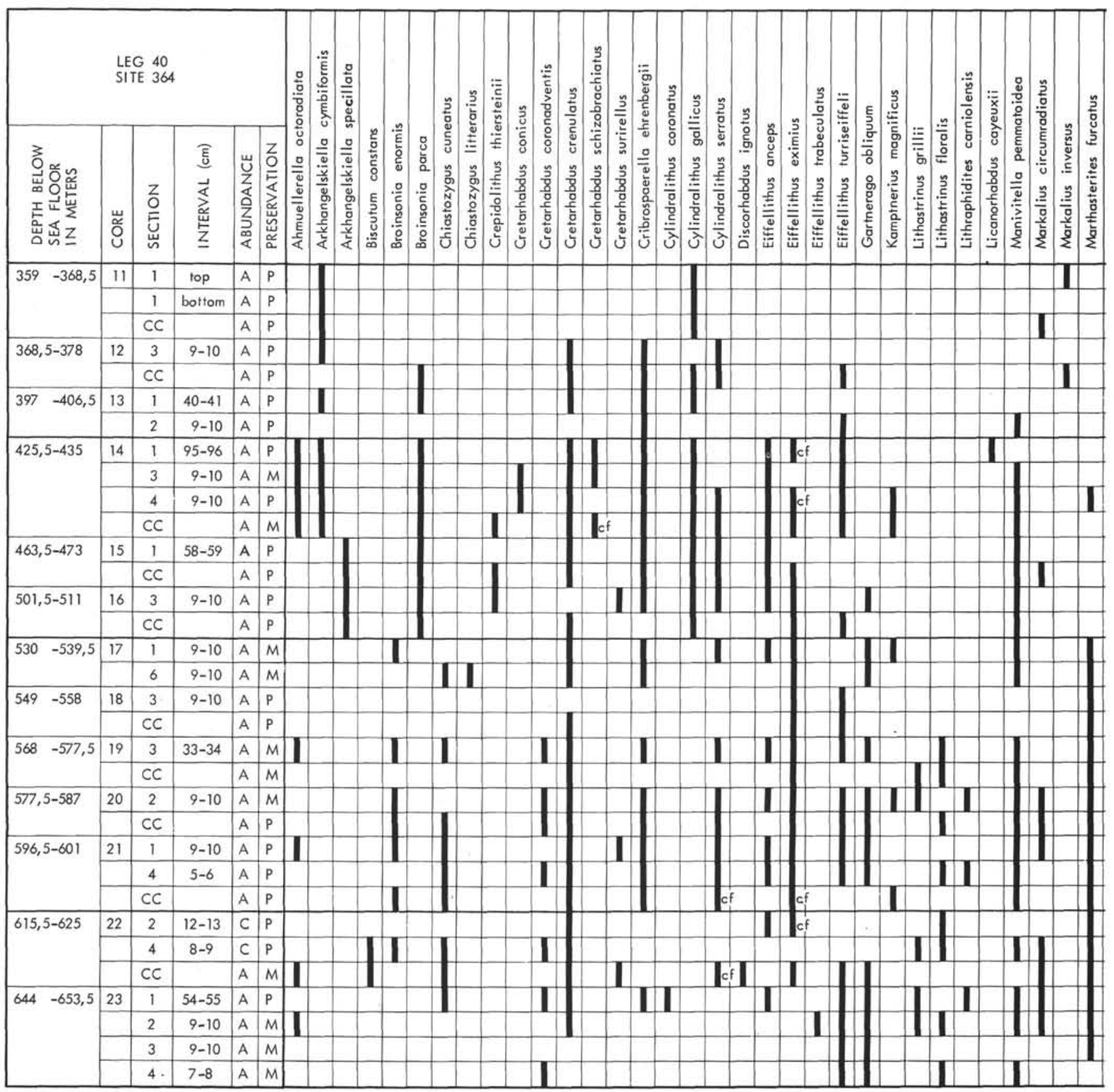

Lithraphidites alatus does not permit to distinguish between upper Albian and Cenomanian. If this Cenomanian marker should be absent for ecological reasons, Cenomanian sediments could be present in the upper part of the interval.

Cores 34 to $41-2,139-141 \mathrm{~cm}(872-1007 \mathrm{~m})$ contain coccoliths of the lower to middle Albian Prediscosphaera cretacea Zone. The lower part of Core 41, Section 3-6 and core catcher, and Core 42 (1007-1033.5 $\mathrm{m})$ yield only poorly preserved assemblages of the Parhabdolithus angustus Zone. This zone ranges from upper Aptian to lower Albian, but the presence in these cores of Hayesites albiensis suggests a lower Albian age for this interval.

Core $43(1033.5-1043 \mathrm{~m})$ is barren of calcareous nannofossils.

\section{SITE 365 \\ Angola Basin (lat $11^{\circ} 39.10^{\prime} \mathrm{S}$, long $11^{\circ} 53.72^{\prime} \mathrm{E}$, water depth $3018 \mathrm{~m}$ )}

Only the first three cores of this site contain calcareous nannofossils

In Core 1 ( 225 to $234.5 \mathrm{~m}$ below sea floor) some samples are barren, some contain diatoms, silicoflagellates, Radiolaria, and Quaternary coccoliths which could represent down-hole contamination. In Core 1, Section 6 and in the core catcher the moderate to poorly preserved nannofossils with Marthasterites furcatus are of Santonian/Coniacian age.

Core 2, together with barren samples, contains assemblages of probably upper Albian age in Section 3, while those of the core catcher seem to be younger, 


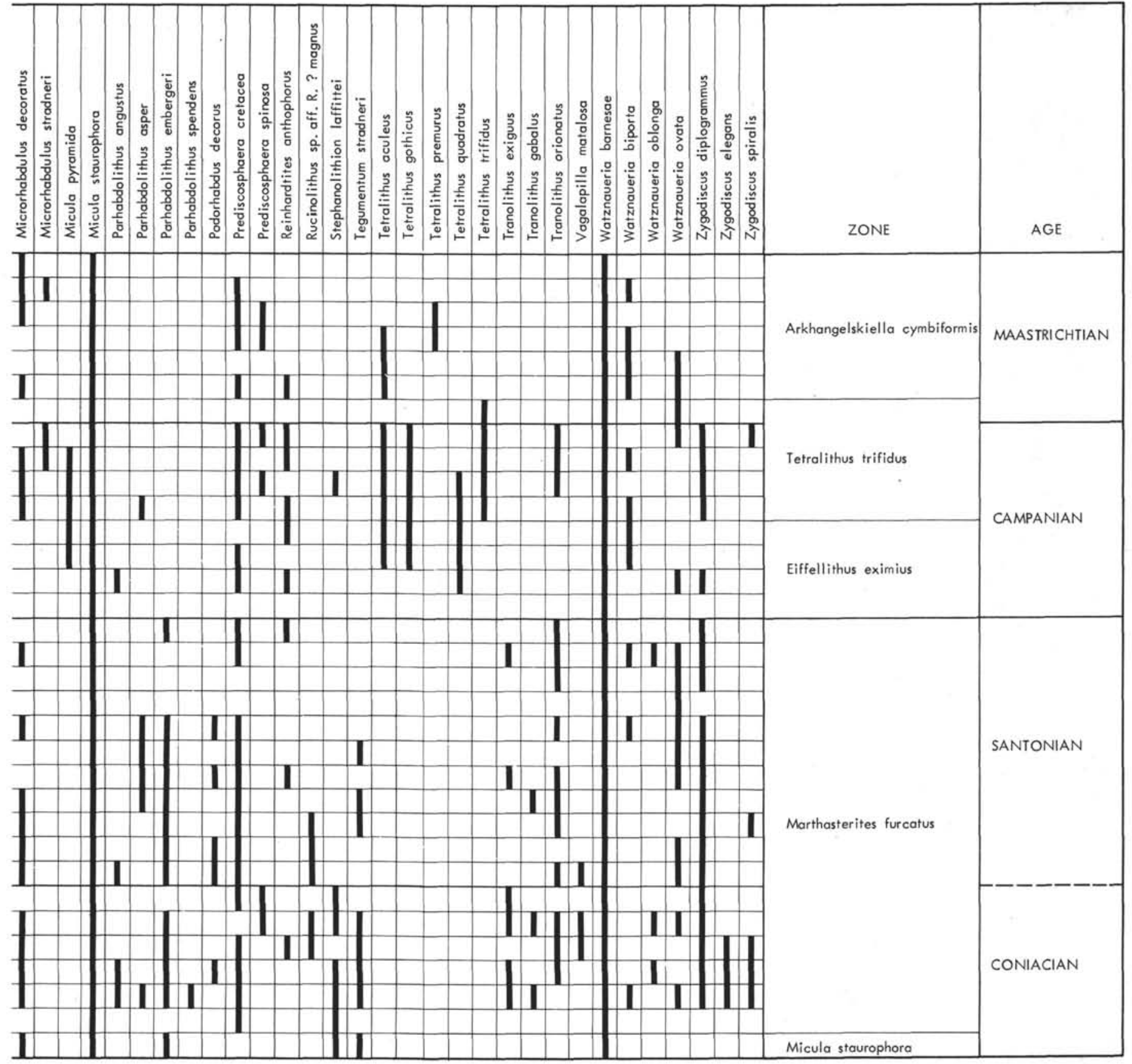

probably post-Santonian, by the presence of Micula staurophora and the absence of the solution-resistant Lithastrinus floralis.

Sections 1 to 3 of Core 3 are barren of calcareous nannofossils. Two core-catcher samples of this core were examined. The light colored one contains abundant, moderately preserved nannofloras of upper Albian age. The dark one contains abundant coccolith fragments which suggest strong dissolution effects.

Core 4 does not contain any preserved coccoliths, except for some rare Watznaueria, but small fragments are abundant in the core-catcher sample.

The remaining part of the section, Cores 5-7, are barren of calcareous nannofossils.

\section{ACKNOWLEDGMENTS}

The authors wish to thank H.E. Franz (Zürich) for the Scanning Electron Microscope micrographs and C. Brogiato (Padua) for the Light Microscope photographs and for the preparation of the plates. Gratitude is expressed to Padua University for having granted to one of the authors (FPD) the leave of absence necessary to participate in Leg 40 .

\section{REFERENCES}

Bramlette, M.N. and Sullivan, F.R., 1961. Coccolithophorids and related nannoplankton on the early Tertiary in California: Micropaleontology, v. 7, p. 129288.

Bukry, D., 1973. Low-latitude coccolith biostratigraphic zonation. In Edgar, N.T., Saunders, J.B., et al., Initial 
TABLE 14

Distribution of Albian Calcareous Nannofossils at Site 364

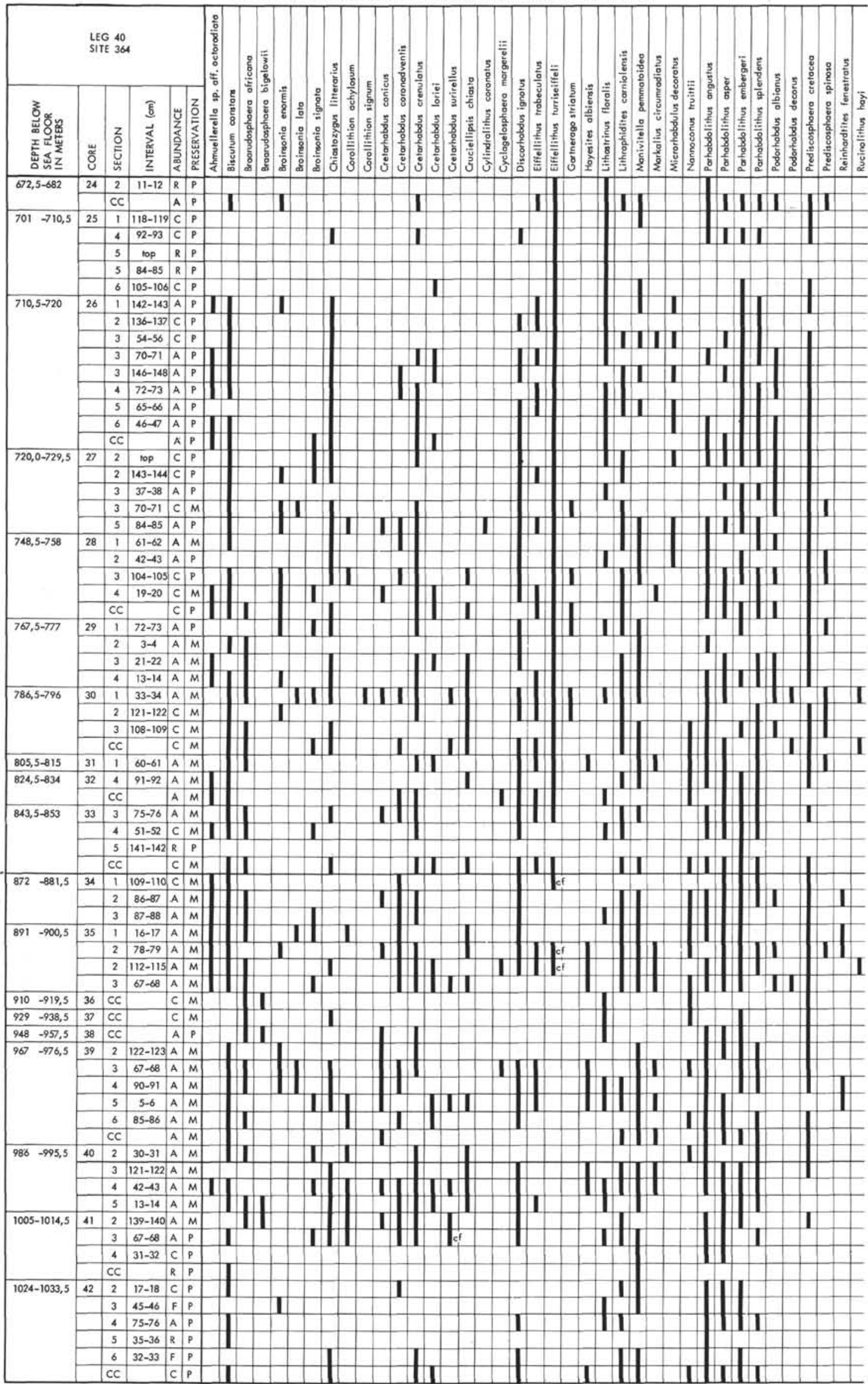


TABLE 14 - Continued

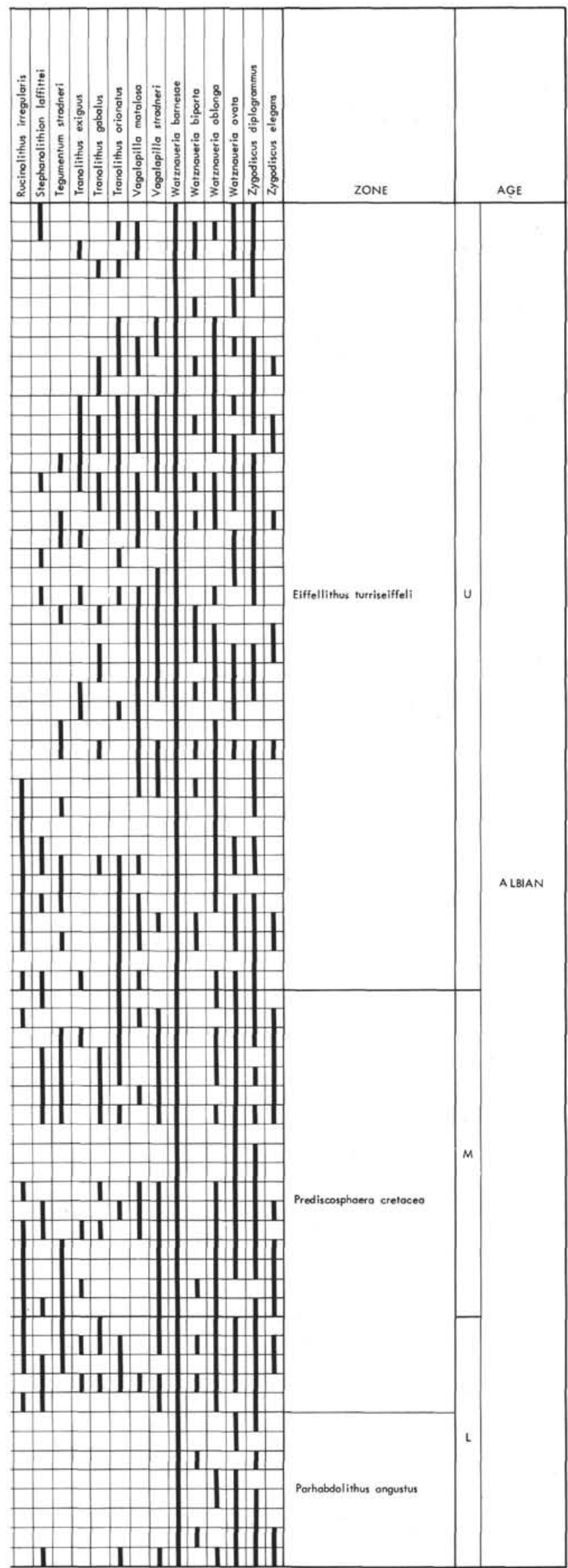

Reports of the Deep Sea Drilling Project, Volume 15: Washington (U.S. Government Printing Office), p. 685703.

, 1975. Coccolith and silicoflagellate stratigraphy, Northwestern Pacific Ocean, Deep Sea Drilling Project Leg 32. In Larson, R.L., Moberly, R., et al., Initial Reports of the Deep Sea Drilling Project, Volume 32: Washington (U.S. Government Printing Office), p. 677701.

Bukry, D. and Bramlette, M.N., 1970. Coccolith age determinations Leg 3, Deep Sea Drilling Project. In Maxwell, A.E., et al., Initial Reports of the Deep Sea Drilling Project, Volume 3: Washington (U.S. Government Printing Office), p. 589-611.

Cepek, P. and Hay, W.W., 1969. Calcareous nannoplankton and biostratigraphy of the Upper Cretaceous: Gulf. Coast. Assoc. Geol. Soc. Trans., v. 19, p. 323-336.

Manivit, H., 1971. Nannofossiles calcaires du Cretacé francais (Aptien-Maestrichtien). Essai de biozonation appuyée sur les stratotypes: Thesis Facult. Sci. Orsay, p. 1-187.

Martini, E., 1969. Nannoplankton aus dem Latdorf (locus typicus) und weltweite Parallelisierungen im oberen Eozän und unteren Oligozän: Senckenberg. Lethaea, v. 50, p. 117-159.

, 1971. Standard Tertiary and Quaternary calcareous nannoplankton zonation: Plankt. Conf. Second Roma, 1970, Proc., v. 2, p. 739-785.

- 1976. Cretaceous to Recent Calcareous Nannoplankton from the Central Pacific Ocean (DSDP Leg 33). In Schlanger, S.O., Jackson, E.D., et al., Initial Reports of the Deep Sea Drilling Project, Volume 33, Washington (U.S. Government Printing Office), p. 383423.

Perch-Nielsen, K., 1972. Remarks on Late Cretaceous to Pleistocene coccoliths from the North Atlantic. In Laughton, A.S., Berggren, W.A., et al., Initial Reports of the Deep Sea Drilling Project, Volume 12: Washington (U.S. Government Printing Office), p. 1003-1069.

, 1977. Albian to Pleistocene calcareous nannofossils from the western South Atlantic, DSDP Leg 39. In PerchNielsen, K., Supko, P.R., et al., Initial Reports of the Deep Sea Drilling Project, Volume 39: Washington (U.S. Government Printing Office), p. 699-823.

Proto Decima, F., 1966. Correlazioni tra zone a foraminiferi planctonici e zone a discoasteridi nell'Eocene inferiore di Pederobba (Trevigiano occidentale): Mem. Acc. Patavina SS. LL. AA., Cl. Sc. Mat. Nat., v. 79, p. 3-13.

Proto Decima, F., Roth, P.H., and Todesco, L., 1975. Nannoplancton calcareo del Paleocene e dell'Eocene della Sezione di Possagno. In Bolli, H.M., Monografia micropaleontologica sul Paleocene e l'Eocene di Possagno, Provincia di Treviso, Italia: Schweiz. Paläont. Abhandl., v. 97 , p. $35-55$.

Roth, P.H., 1973. Calcareous Nannofossils-Leg 17, Deep Sea Drilling Project. In Winterer, E.L., Ewing, J.I., et al., Volume 17: Washington (U.S. Government Printing Office), p. 695-795.

Ryan, W.B.F., Cita, M.B., Dreyfus Rawson, M., Burckle, L.H., and Saito, T., 1974. A paleomagnetic assignment of Neogene stage boundaries and the development of isochronous Datum Planes between the Mediterranean, the Pacific and Indian Oceans in order to investigate the response of the World Ocean to the Mediterranean "Salinity Crisis": Riv. Ital. Paleontol. Strat., v. 80, p. 631-688.

Thierstein, H.R., 1971. Tentative Lower Cretaceous calcareous nannoplankton zonation: Eclog. Geol. Helv., v. 64, p. $459-488$.

, 1973. Lower Cretaceous calcareous nannoplankton biostratigraphy: Abh. Geol. B.A. (Wien), v. 29, p. 1-12. 


\section{PLATE 1}

Figures 1, 3,4 Gephyrocapsa oceanica Kamptner. Sample 364-1 CC.

la. Phase contrast.

1b, 3, 4. Cross-polarized light $(\times 2800)$.

Figures 2, 5 Gephyrocapsa caribbeanica Boudreaux and Hay. Sample 364-1, CC.

2a, 5a. Phase contrast.

$2 b, 5 b$. Cross-polarized light $(\times 2800)$.

Figures 6,7 Cricolithus jonesii Cohen.

6a. Phase contrast; 6b. Cross-polarized light $(\times 2800)$. Sample 364-1, CC.

7a. Transmitted light; 7b. Cross-polarized light $(\times 2800)$. Sample 364-3, CC.

Figures 8,9,13 Emiliania ovata Bukry.

$8 \mathrm{a}, 9 \mathrm{a}$. Phase contrast; $8 \mathrm{~b}, 9 \mathrm{~b}$. Cross-polarized light $(\times 2800)$. Sample 364-1, CC.

13a. Phase contrast; 13b. Cross-polarized light $(\times 2800)$. Sample 364-3-3, 9-10 cm.

Figures 10-12 Sphenolithus heteromorphus Deflandre. Sample 364-5-3, 9-10 cm.

10a-12a. Transmitted light.

$10 \mathrm{~b}-12 \mathrm{~b}$. Phase contrast.

10c- $12 \mathrm{c}$. Long axis $0^{\circ}$ to crossed nicols.

10d-12d. Long axis $45^{\circ}$ to crossed nicols $(\times 2800)$.

Figures 14, 15 Emiliania annula (Cohen). Sample 364-3, CC.

$14 \mathrm{a}, 15 \mathrm{a}$. Phase contrast.

$14 \mathrm{~b}, 15 \mathrm{~b}$. Cross-polarized light $(\times 2800)$.

Figure 16 Sphenolithus moriformis (Brönnimann and Stradner). Sample 364-5-3, 9$10 \mathrm{~cm}$.

16a. Transmitted light.

16b. Phase contrast.

16c. Cross-polarized light $(\times 2800)$.

Figure 17 Sphenolithus abies Deflandre. Sample 364-5-3, 9-10 cm.

$17 \mathrm{a}, 17 \mathrm{~b}$. Phase contrast.

17c. Long axis $0^{\circ}$ to crossed nicols.

$17 \mathrm{~d}$. Long axis $45^{\circ}$ to crossed nicols $(\times 2800)$.

Figure 18 Umbilicosphaera mirabilis Lohmann. Sample 364-1-2, 9-10 cm.

18a. Phase contrast.

18b. Cross-polarized light $(\times 2800)$.

Figure 19 Pontosphaera multipora (Kamptner). Sample $364-4-4,9-10 \mathrm{~cm}$.

19a. Transmitted light.

19b. Phase contrast.

19c. Long axis $0^{\circ}$ to crossed nicols.

19d. Long axis $45^{\circ}$ to crossed nicols $(\times 2800)$.

Figure 20 Syracosphaera histrica Kamptner. Sample 364-1-2, 9-10 cm.

20a. Phase contrast.

20b. Cross-polarized light $(\times 2800)$.

Figure $21 \quad$ Minilitha convallis Bukry. Sample 364-4-6, 9-10 cm.

21a. Transmitted light.

21 b. Cross-polarized light $(\times 2800)$.

Figure 22 Cyclococcolithus leptoporus (Murray and Blackman). Sample 364-1-2, 9$10 \mathrm{~cm}$.

22a. Phase contrast.

22 b. Cross-polarized light $(\times 2800)$.

Figures 23, 24 Helicosphaera sellii (Bukry and Bramlette). Sample 364-2, CC.

23a, 24a. Phase contrast.

23b, 24b. Cross-polarized light $(\times 2800)$.

Figure 25 Helicosphaera intermedia Martini. Sample 364-5-3, 9-10 cm.

25a. Phase contrast.

25b. Cross-polarized light $(\times 2800)$. 
PLATE 1

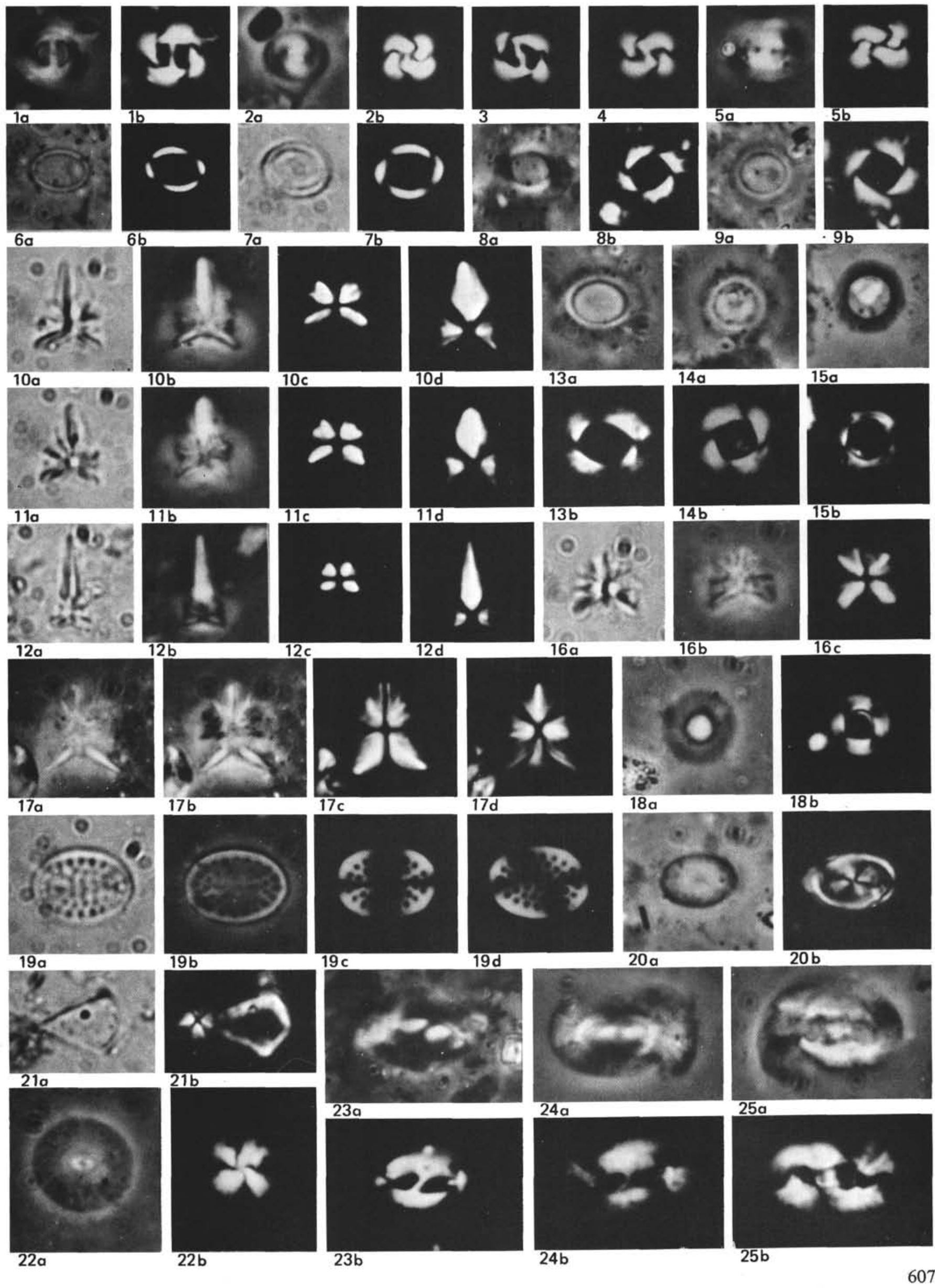




\section{PLATE 2}

Figure 1 Helicosphaera ampliaperta Bramlette and Wilcoxon. Sample 364-5-3, 9-10 cm.

1a. Phase contrast.

1b. Cross-polarized light $(\times 2800)$.

Figure 2 Helicosphaera carteri (Wallich). Sample 364-4, CC.

2a. Phase contrast.

2b. Cross-polarized light $(\times 2800)$.

Figure 3 Cyclicargolithus floridanus (Roth and Hay). Sample 364-5-3, 9-10 cm.

3a. Transmitted light.

3b. Phase contrast.

3c. Cross-polarized light $(\times 2800)$.

Figure 4 Coronocyclus nitescens (Kamptner). Sample 364-53, 9-10 cm.

4a. Phase contrast.

4b. Cross-polarized light $(\times 2800)$.

Figure 5 Cyclicargolithus abisectus (Müller). Sample 364-5-3, 9-10 cm.

5a. Phase contrast.

5b. Cross-polarized light $(\times 2800)$.

Figure 6 Cyclococcolithus macintyrei Bukry and Bramlette. Sample 364-4, CC.

6a. Phase contrast.

6b. Cross-polarized light $(\times 2800)$.

Figure 7 Thoracosphaera saxea Stradner. Sample 364-1-3, 9-10 cm.

7a. Transmitted light.

7b. Cross-polarized light $(\times 2800)$.

Figure $8 \quad$ Reticulofenestra pseudoumbilica (Gartner). Sample 364-4, CC.

8a. Phase contrast.

8b. Cross-polarized light $(\times 2800)$.

Figures 9-12 Problematic calcareous nannofossil. Sample 3618-0, 9-10 cm.

9,10 . Scanning electron micrographs $(\times 1500$, $\times 6000$ ).

11,12a. Transmitted light.

12 b. Cross-polarized light $(\times 1500, \times 2800)$. 
PLATE 2

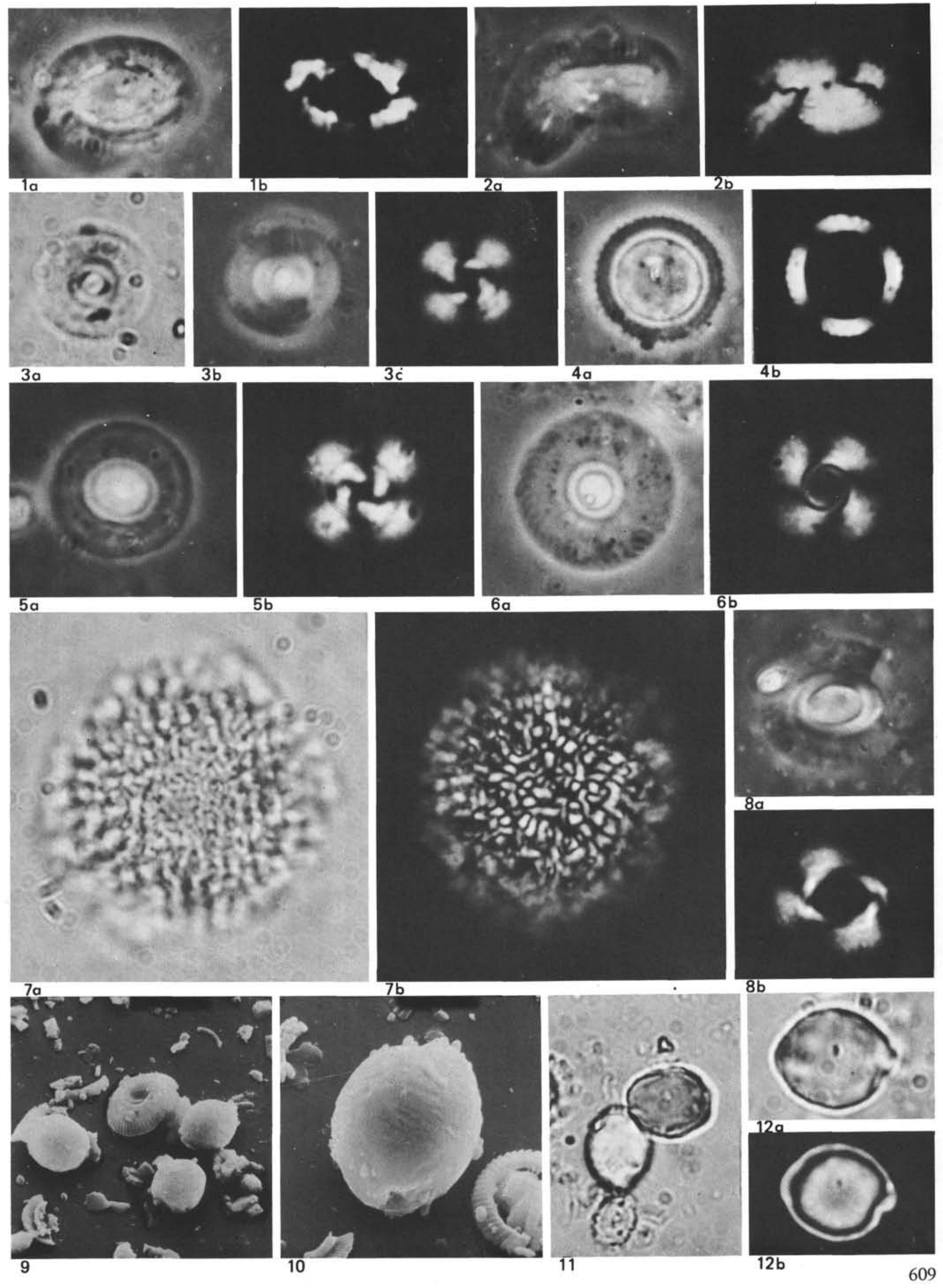




\section{PLATE 3}

Figures 1,8 Scyphosphaera apsteinii Lohmann.

1a, 2a. Transmitted light.

1b, 2b. Cross-polarized light $(\times 2800)$.

1. Sample 364-4-6, 9-10 cm.

2. Sample $364-4$, CC.

Figure 2 Scyphosphaera pulcherrima Deflandre. Sample 364-4-6, 9-10 cm.

2a. Transmitted light.

2b. Cross-polarized light $(\times 2800)$.

Figures 3,4 Scyphosphaera globulosa Kamptner.

3a, 4a. Transmitted light.

3 b, 4b. Cross-polarized light $(\times 2800)$.

3. Sample 364-3-1, 33-34 cm.

4. Sample $364-3$, CC.

Figure 5 Scyphosphaera amphora Deflandre. Sample 364-31, 33-34 cm.

5a. Transmitted light.

5b. Cross-polarized light $(\times 2800)$.

Figures 6,7 Scyphosphaera intermedia Deflandre. Sample 3643 , CC.

6a, 7a. Transmitted light.

7b, 7c. Cross-polarized light.

\section{PLATE 4}

Figures 1-4,6, Ceratolithus rugosus Bukry and Bramlette.

7,9 la- 4a, 6a, 7a, 9a. Transmitted light.

Ib, 2b, 3b, 3c. Phase contrast.

1c, 2c, 3d, 4b, 6b, 7b, 9b. Cross-polarized light $(\times 2800)$.

1- 3, 6, 7. Sample 364-3-5, 9-10 cm.

4. Sample 364-3-1, 33-34 cm.

9. Sample $364-3-2,9-10 \mathrm{~cm}$.

Figures 5, 8, 10, Ceratolithus acutus Gartner and Bukry. Sample $11 \quad 364-3-6,9-10 \mathrm{~cm}$.

5a, 8a, 10a, 11a. Transmitted light.

8 b. Phase contrast.

$5 \mathrm{~b}, 8 \mathrm{c}, 10 \mathrm{~b}, 11 \mathrm{~b}$. Cross-polarized light $(\times 2800)$.

Figure 12 Ceratolithus cristatus Kamptner. Sample 364-1-3, 9-10 cm.

12a. Transmitted light.

12b. Phase contrast.

12c. Cross-polarized light $(\times 2800)$.

(see p. 612) 
PLATE 3
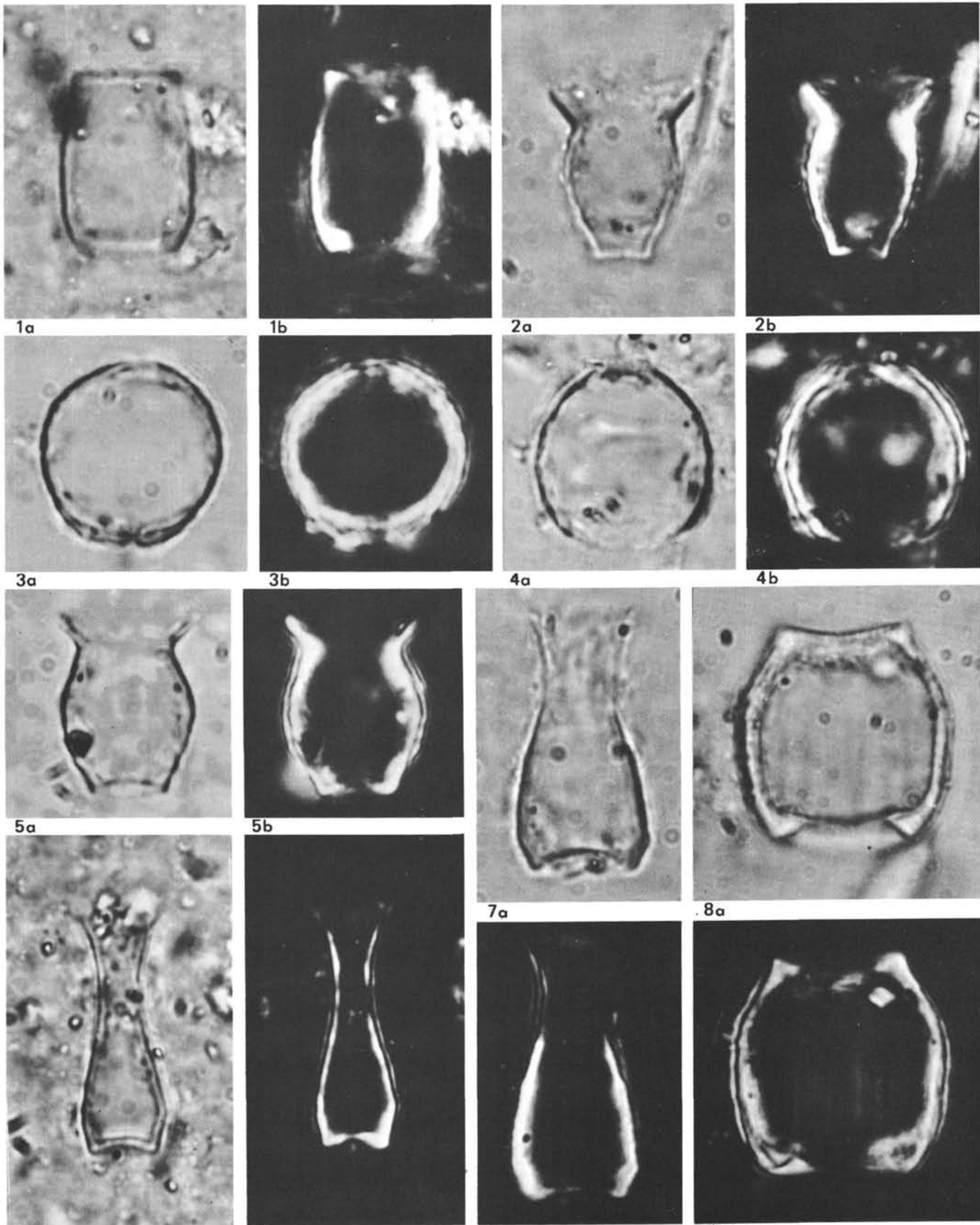

$6 a$
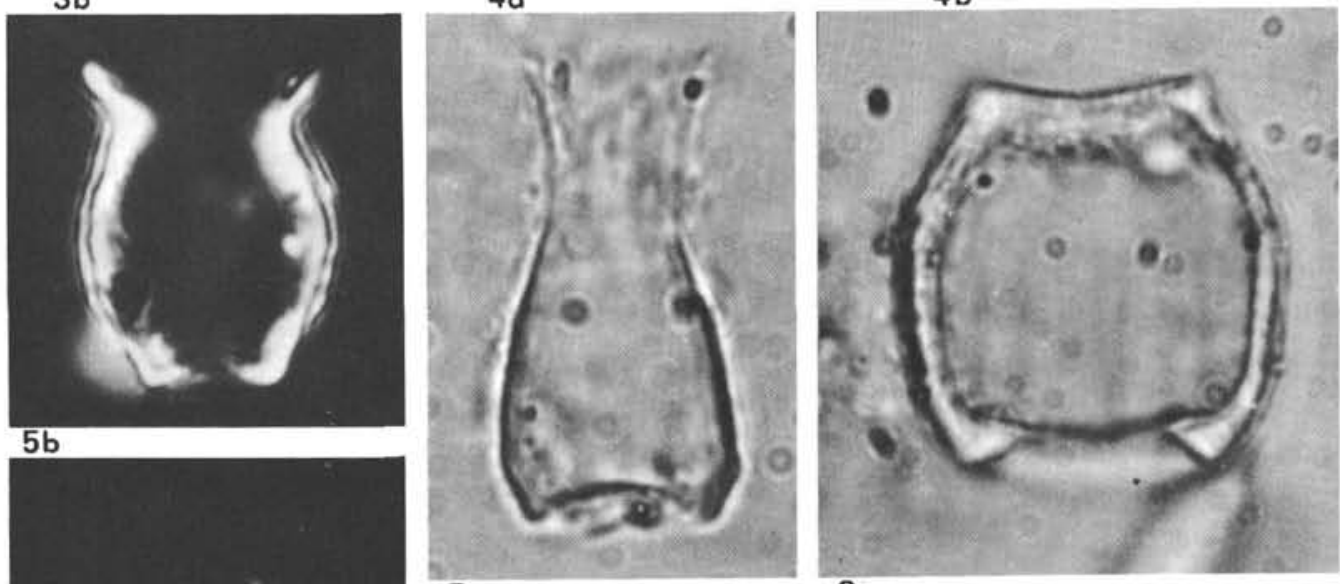

$5 b$
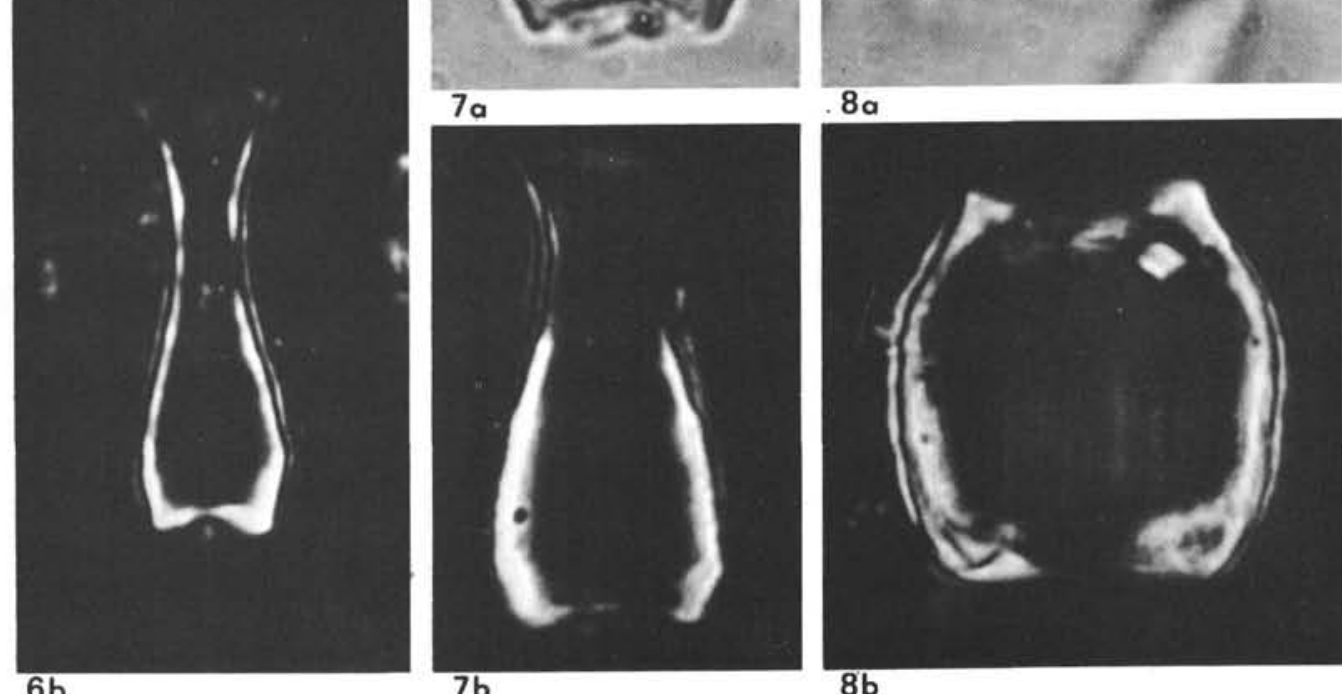

$7 b$

$8 b$ 
PLATE 4

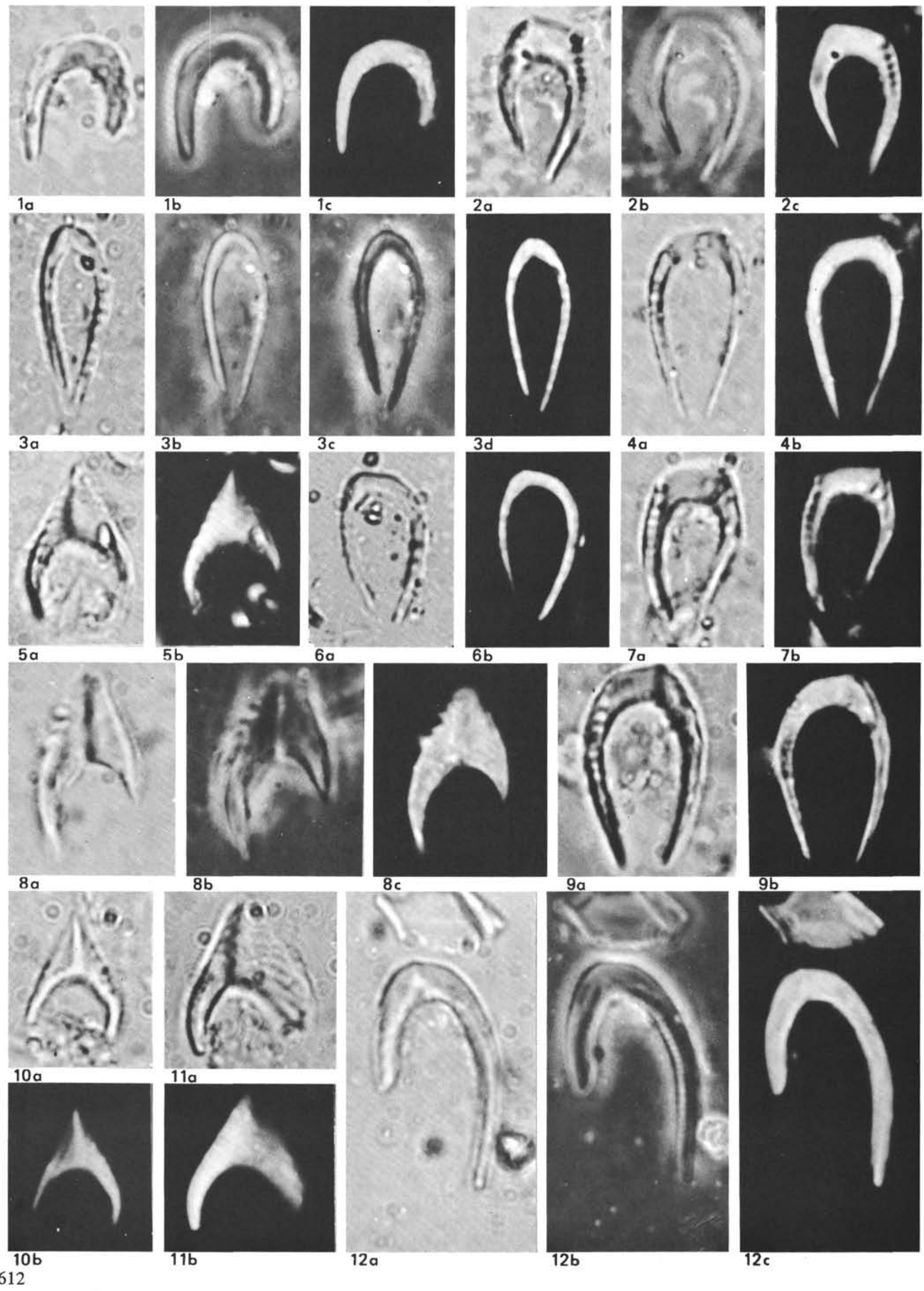




\section{PLATE 5}

Figures 1,2 Rhabdosphaera clavigera Murray and Blackman.

1a, 1b, 2a, 2b. Phase contrast.

1c. Cross-polarized light $(\times 2800)$.

1. Sample 364-1-3, 9-10 cm.

2. Sample $364-1-2,9-10 \mathrm{~cm}$.

Figures 3-7 Amaurolithus delicatus Gartner and Bukry. Sample 364-3, CC.

3, 4a, 5a, 6, 7. Transmitted light.

4 b, 5b. Phase contrast $(\times 2800)$.

Figure $8 \quad$ Amaurolithus amplificus (Bukry and Percival). Sample 360-7-4, 9-10 cm.

8a. Transmitted light.

8 b. Phase contrast $(\times 2800)$.

Figure 9 Amaurolithus tricorniculatus (Gartner). Sample $360-1-4,9-10 \mathrm{~cm}$.

9a. Transmitted light.

9b. Phase contrast $(\times 2800)$.

Figures 10,11 Amaurolithus primus (Bukry and Bramlette). Sample 360-7-4, 9-10 cm.

10a, 11a. Transmitted light.

$10 \mathrm{~b}, 11 \mathrm{~b}$. Phase contrast $(\times 2800)$.

Figure 12 Triquetrorhabdulus rugosus Bramlette and Wilcoxon. Phase contrast $(\times 2800)$. Sample 364-4$6,9-10 \mathrm{~cm}$.

Figure 13 Calcareous crystallites of unknown origin. Sample 364-8-1, 9-10 cm.

13a. Transmitted light.

13b. Cross-polarized light $(\times 2800)$.

Figure 14 Angulolithina arca Bukry. Sample 364-3-5, 9-10 $\mathrm{cm}$.

14a. Transmitted light.

14b. Cross-polarized light $(\times 2800)$.

(see p. 614) 
PLATE 5
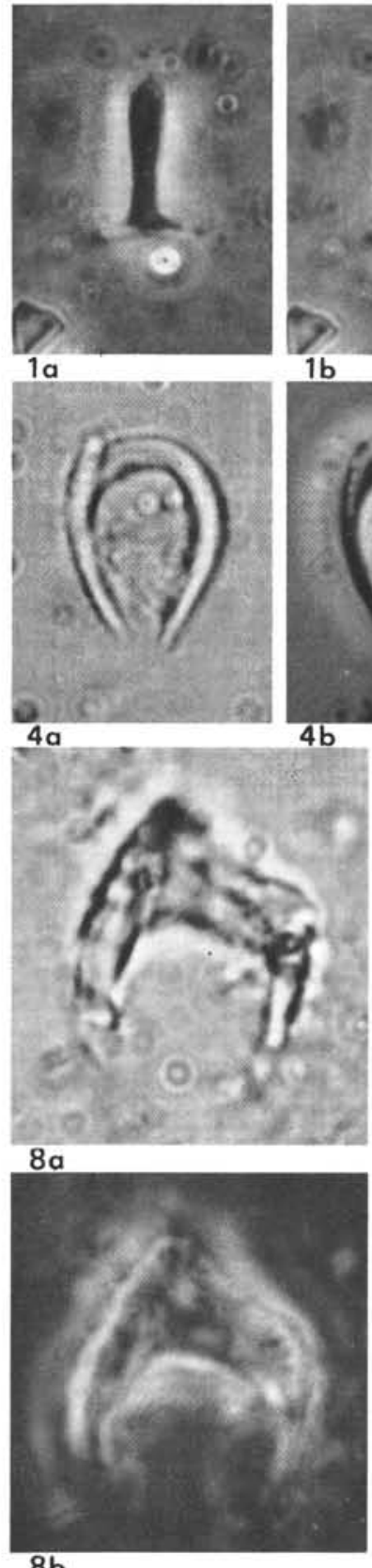

$8 \mathrm{~b}$
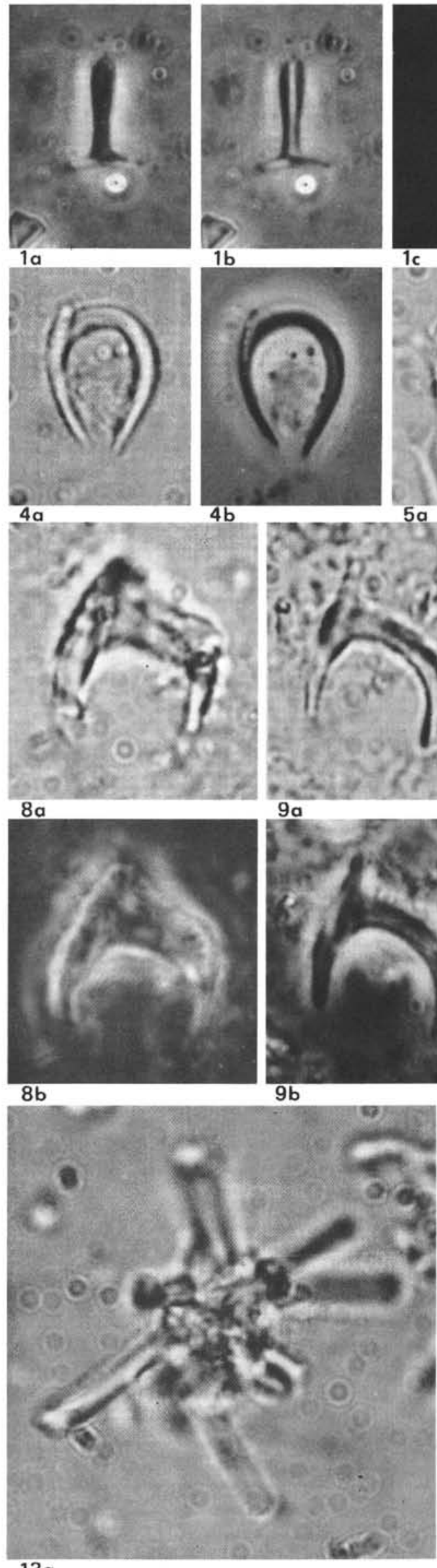

$1 b$
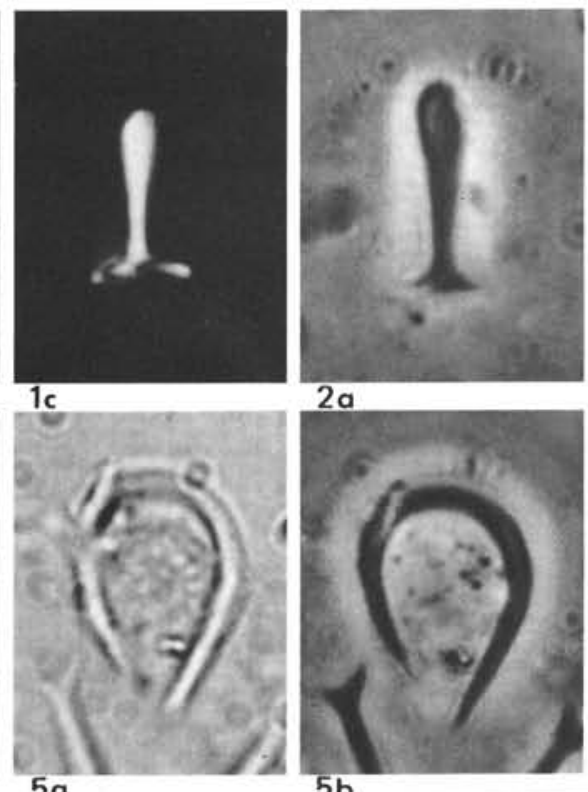

$2 a$

$2 b$
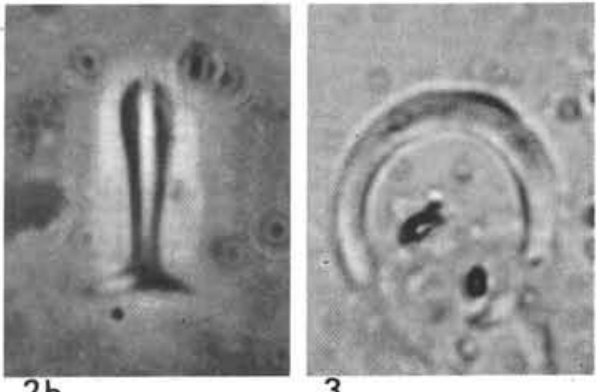

3
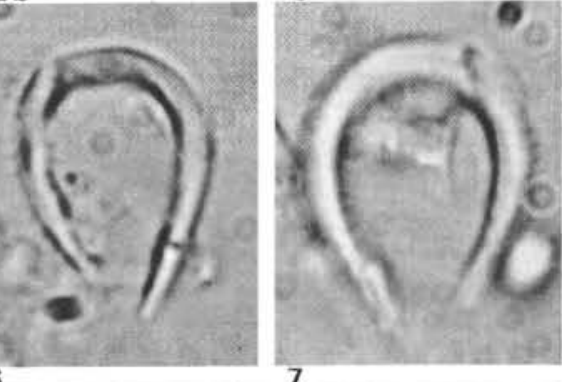
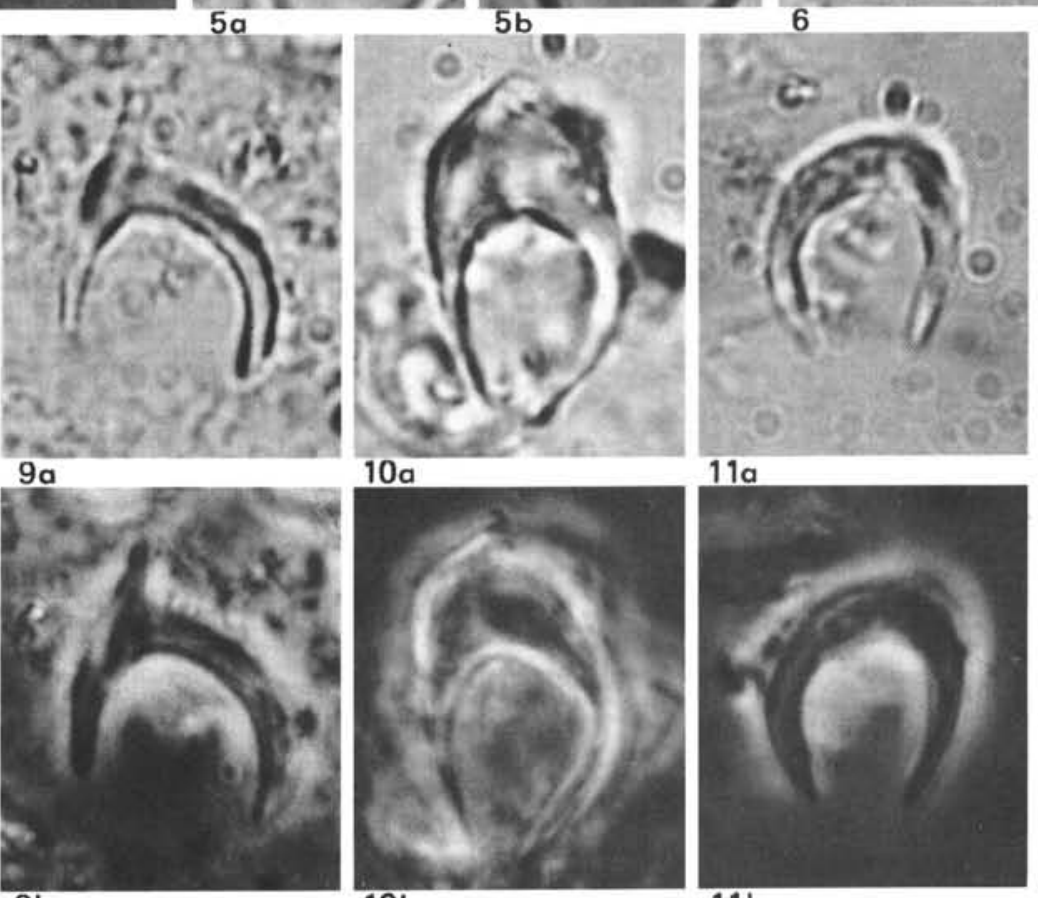

$10 a$

$11 a$

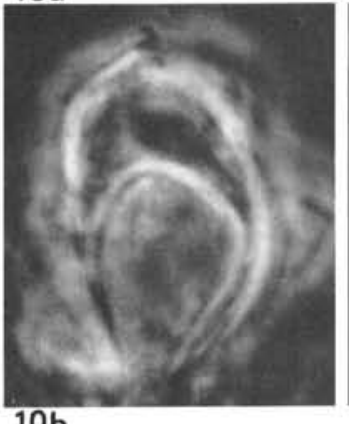

$10 \mathrm{~b}$

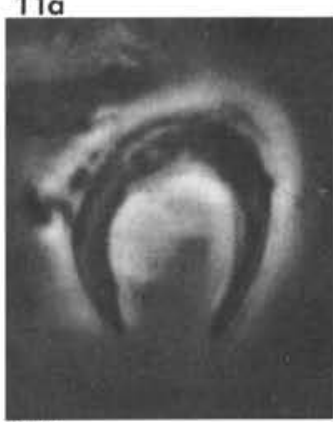

$11 \mathrm{~b}$
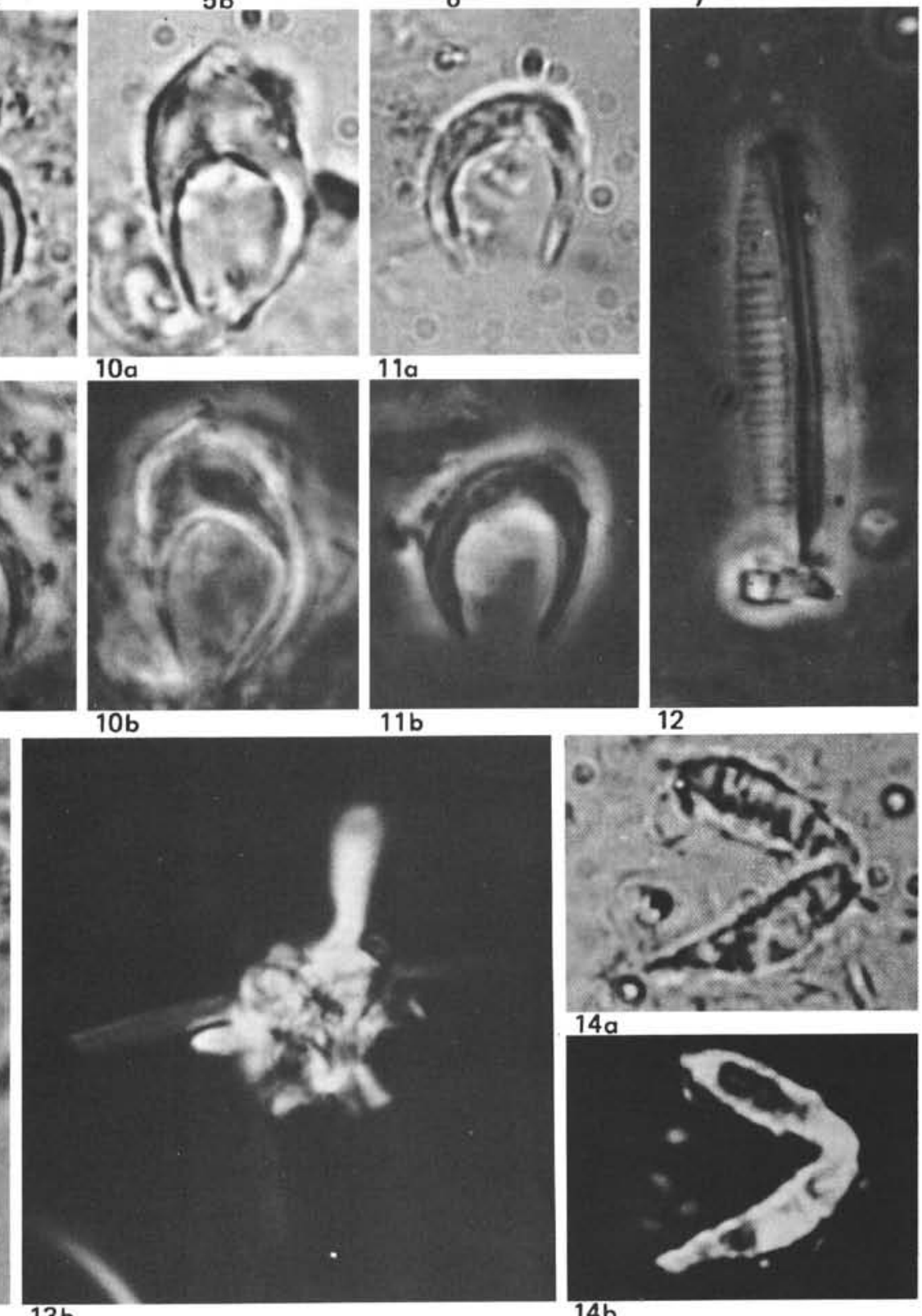


\section{PLATE 6}

Figure $1 \quad$ Discoaster sp.

Transmitted light $(\times 2800)$. Sample $364-4-4,9-10$ $\mathrm{cm}$.

Figure 2 Discoaster asymmetricus Gartner.

Transmitted light $(\times 2800)$. Sample 364-4-6, 9-10 $\mathrm{cm}$.

Figure 3 Discoaster brouweri Tan Sin Hok.

Transmitted light $(\times 2800)$. Sample $364-3$, CC.

Figures 4, 5 Discoaster calcaris Gartner. Sample 364-4-6, 9-10

$\mathrm{cm}$.

4a, 5. Transmitted light.

4b. Phase contrast $(\times 2800)$.

Figure 6 Discoaster hamatus Martini and Bramlette. Sample 364-4, CC.

6a. Transmitted light, low focus.

6b. Transmitted light, high focus $(\times 2800)$.

Figure 7 Discoaster neorectus Bukry. Transmitted light (×2800). Sample 364-4-6, 9-10 cm.

Figures 8,9 Discoaster druggii Bramlette and Wilcoxon. Sample 364-5-3, 9-10 cm.

9a. Transmitted light.

8 , 9b. Phase contrast $(\times 2800)$.

(see p. 616)

\section{PLATE 7}

Figures 1-3 Discoaster berggrenii Bukry. Transmitted light (×2800). Sample 364-4-4, 9-10 cm.

Figure 4 Discoaster quinqueramus Gartner. Transmitted light $(\times 2800)$. Sample $364-3-5,9-10 \mathrm{~cm}$.

Figures 5-8 Discoaster moorei Bukry.

5. Phase contrast $(\times 2800)$.

6- 8. Transmitted light $(\times 2800)$.

5. Sample 364-5-3, 9-10 cm.

6- 8. Sample 364-4-6, 9-10 cm.

Figure 9 Discoaster pseudovariabilis Martini and Worsley. Sample 364-3-1, 33-34 cm.

$9 \mathrm{a}, 9 \mathrm{~b}$. Phase contrast.

9c, 9d. Transmitted light $(\times 2800)$.

Figures 10-14 Discoaster variabilis Martini and Bramlette.

Transmitted light $(\times 2800)$.

$10,13,14$. Sample $364-4-6,9-10 \mathrm{~cm}$.

11, 12. Sample $364-4-4,9-10 \mathrm{~cm}$.

Figures 15, 16 Discoaster variabilis decorus Bukry.

Transmitted light $(\times 2800)$.

15. Sample 364-3-5, 9-10 cm.

16. Sample $362-27-1,62-63 \mathrm{~cm}$.

(see p. 617) 
PLATE 6
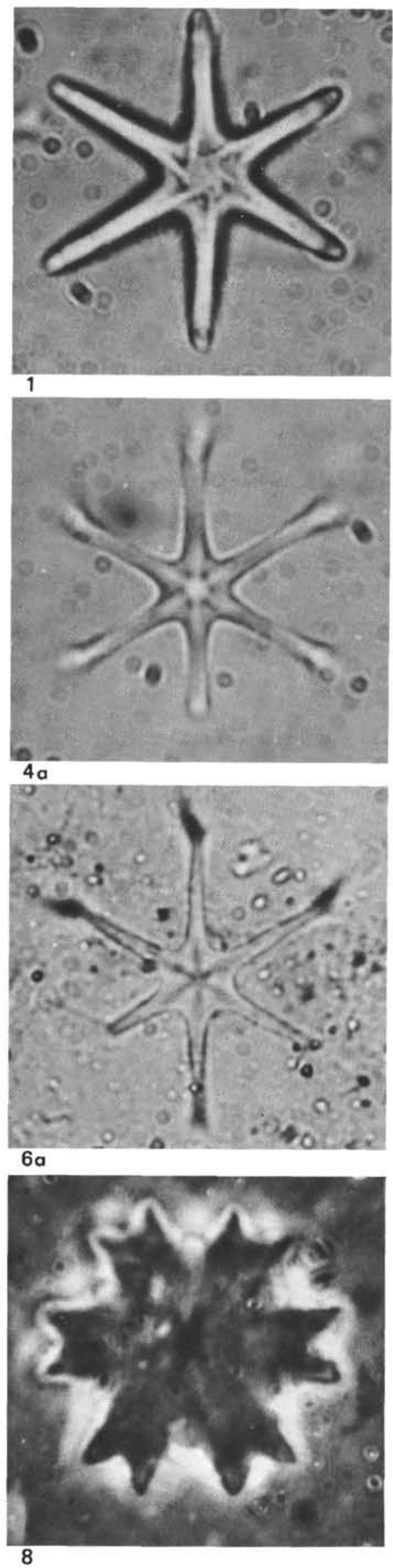
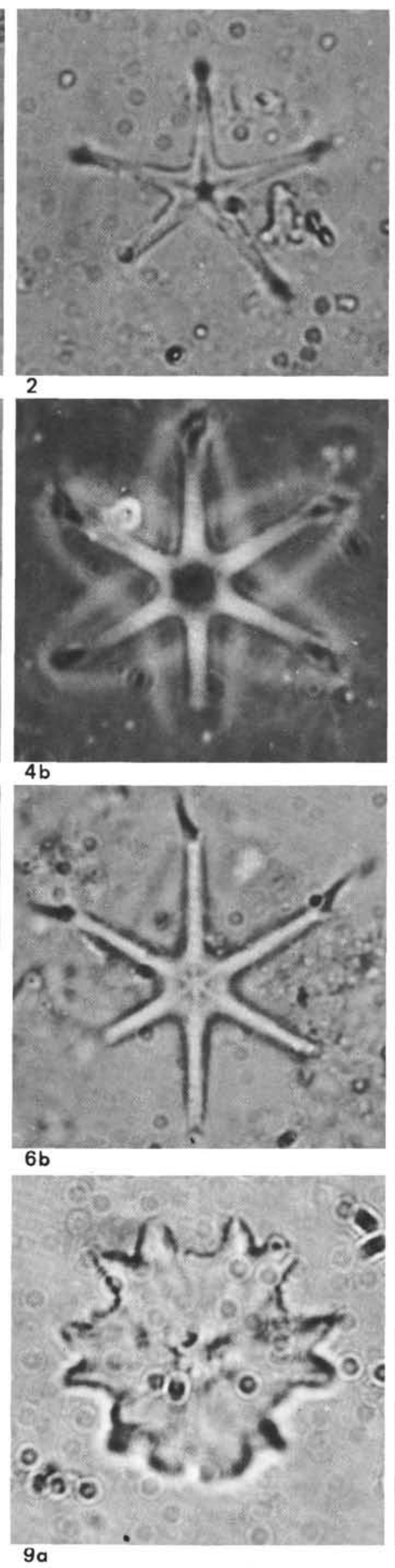
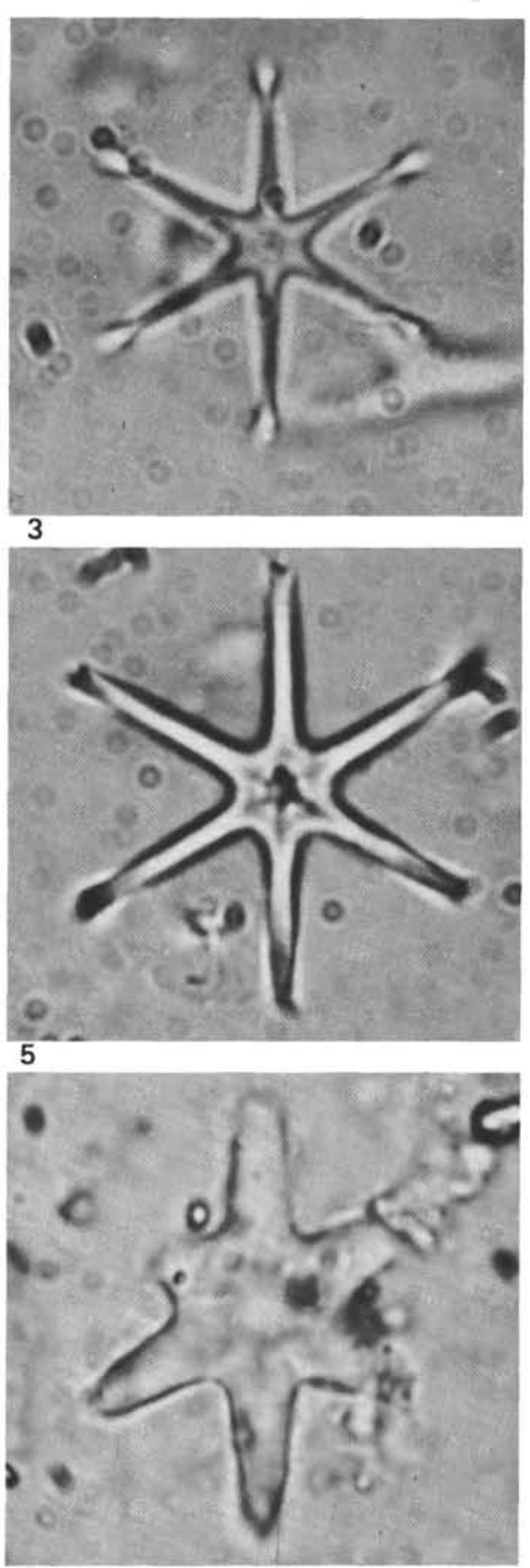

7

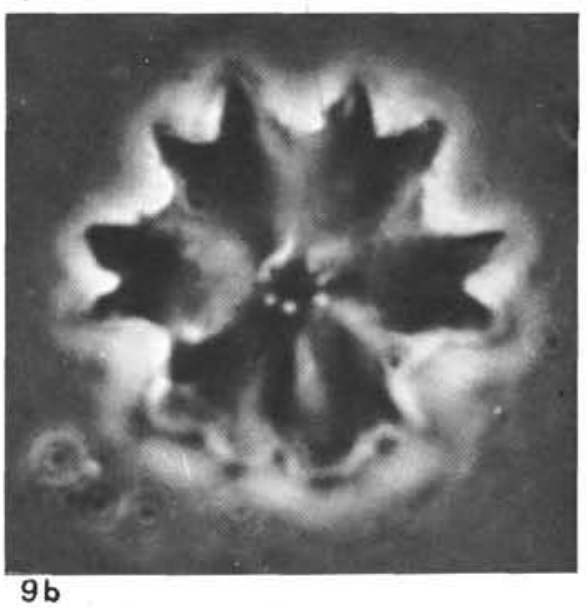




\section{PLATE 7}
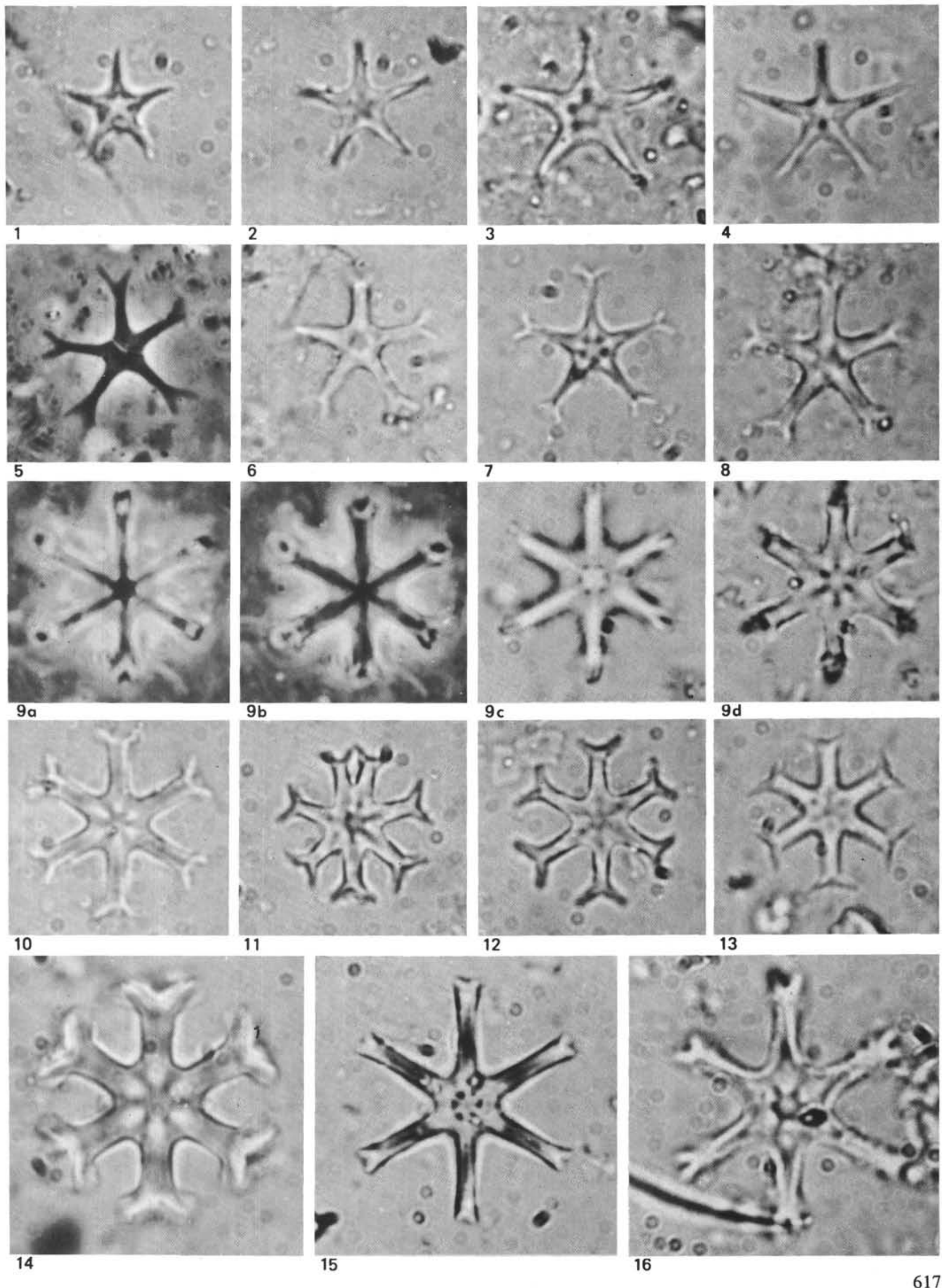


\section{PLATE 8}

Figure 1 Discoaster surculus Martini and Bramlette. Sample 364-3-1, 33-34 cm.

1a. Transmitted light.

lb. Phase contrast $(\times 2800)$.

Figure 2

Discoaster pseudovariabilis Martini and Worsley. Sample 364-3-5, 9-10 cm.

2a. Transmitted light.

2b. Phase contrast $(\times 2800)$.

Figure 3 Discoaster sp. Sample 364-3-3, 9-10 cm.

3a. Transmitted light.

3b. Phase contrast $(\times 2800)$.

Figure 4 Discoaster pentaradiatus Tan Sin Hok. Sample 364-3-5, 9-10 cm.

4a. Transmitted light.

$4 b$, 4c. Phase contrast $(\times 2800)$.

Figure 5 Discoaster exilis Martini and Bramlette. Sample 364-5-3, 9-10 cm.

5a, 5b. Transmitted light.

5c. Phase contrast $(\times 2800)$.

\section{PLATE 9}

Figure 1 Discoaster sp. Sample 364-4, CC.

1a. Transmitted light.

lb. Phase contrast $(\times 2800)$.

Figure 2 Discoaster asymmetricus Gartner. Sample 364-3-6, 9-10 cm.

2a. Transmitted light.

2b. Phase contrast $(\times 2800)$.

Figures 3,6 Discoaster deflandrei Bramlette and Riedel. Sample 364-5-3, 9-10 cm.

3. Transmitted light.

6. Phase contrast $(\times 2800)$.

Figure 4 Discoaster bollii Martini and Bramlette. Transmitted light $(\times 2800)$. Sample 364-4-6, 9-10 $\mathrm{cm}$.

Figure 5 Discoaster challengeri Bramlette and Riedel. Sample 364-4-4, 9-10 cm.

5a. Transmitted light.

5b. Phase contrast $(\times 2800)$.

Figures 7,8 Discoaster loeblichii Bukry. Transmitted light (×2800). Sample 362-27-1, 62-63 cm.

Figure 9 Discoaster neorectus Bukry. Transmitted light (×2800). Sample 360-5-6, 9-10 cm.

Figure 10 Discoaster variabilis decorus Bukry. Transmitted light $(\times 2800)$. Sample 362-27-1, 62-63 cm.

(see p. 620) 


\section{PLATE 8}
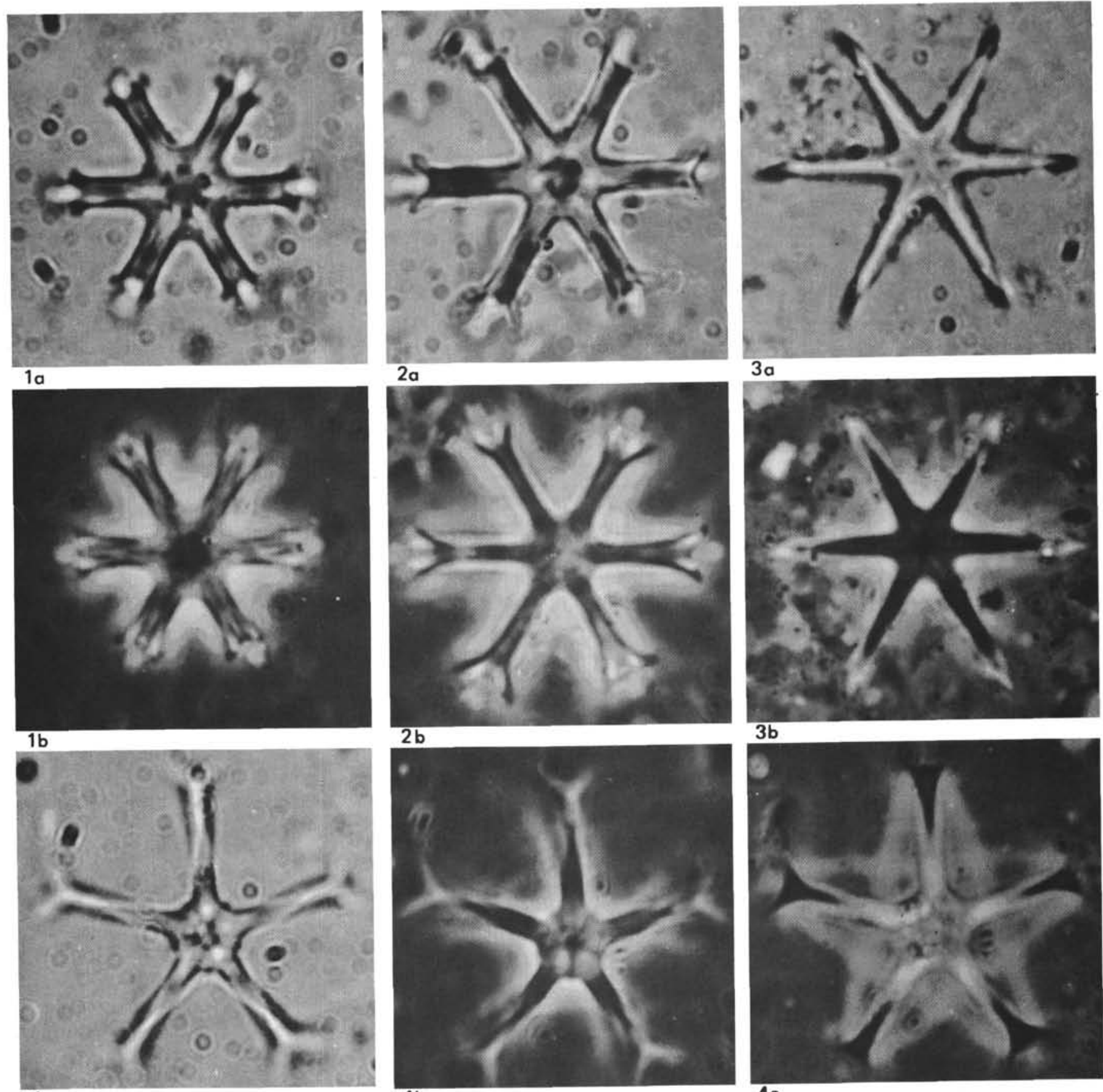

$4 a$

\section{$4 b$}

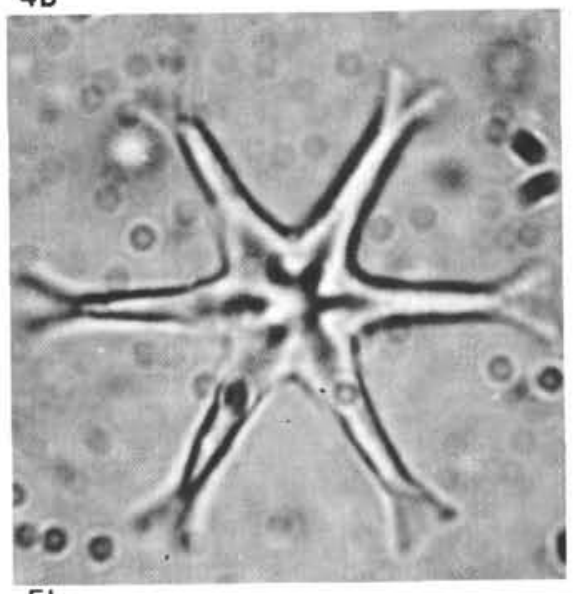

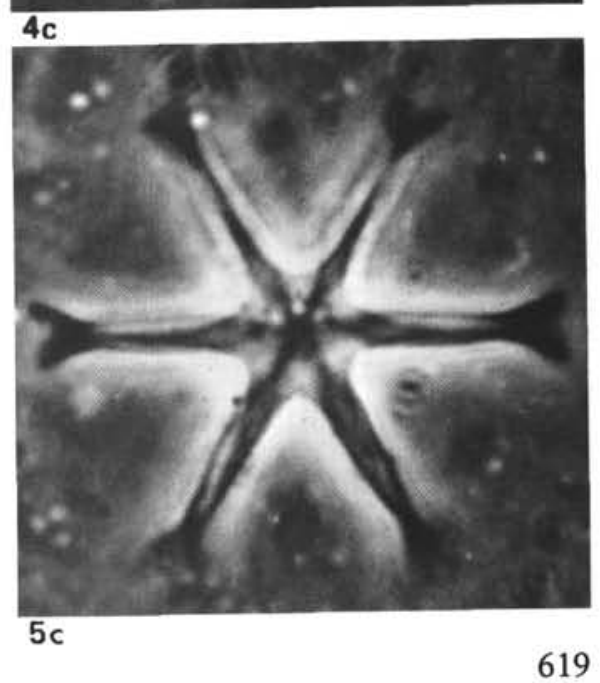


PLATE 9
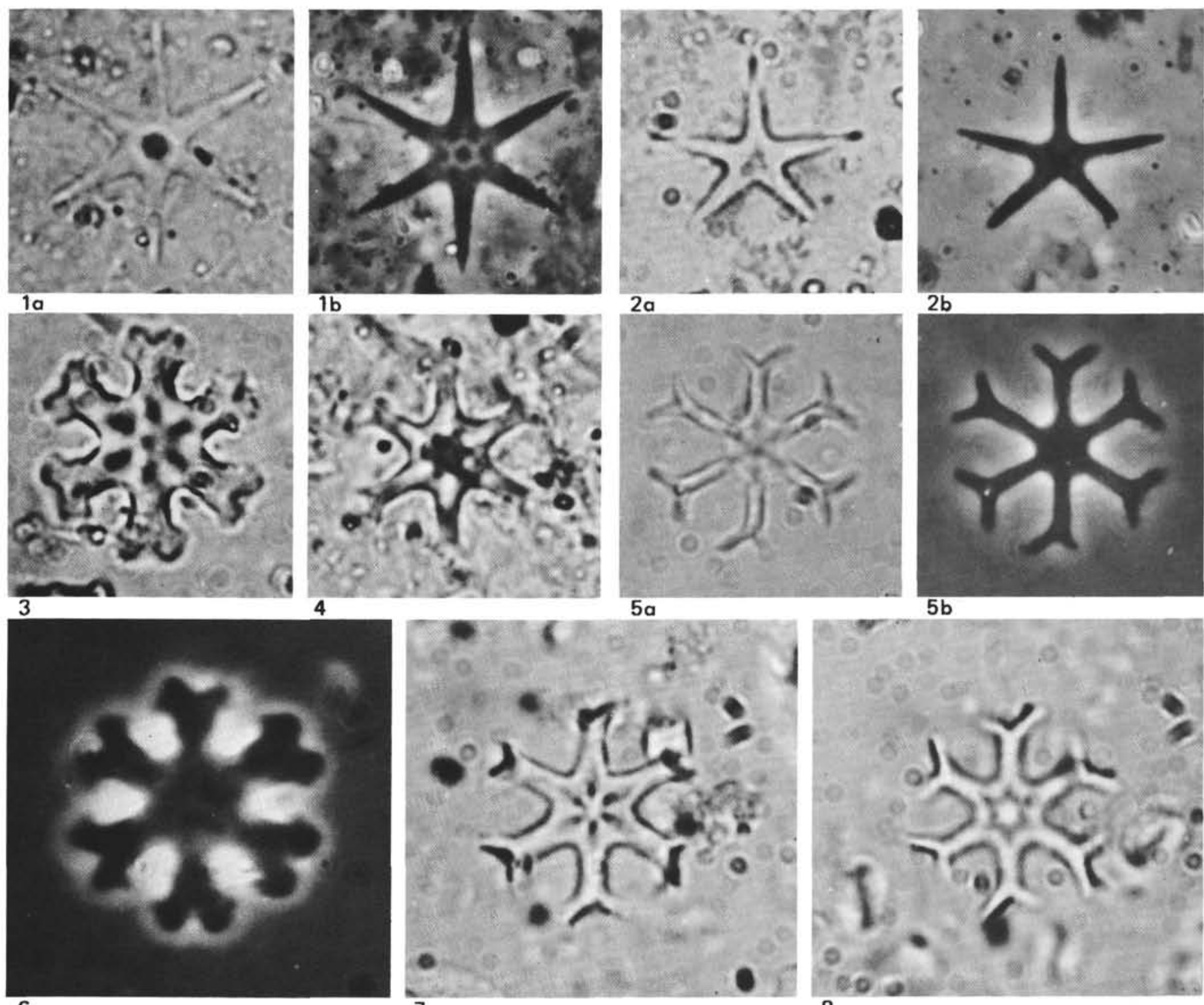

$2 a$
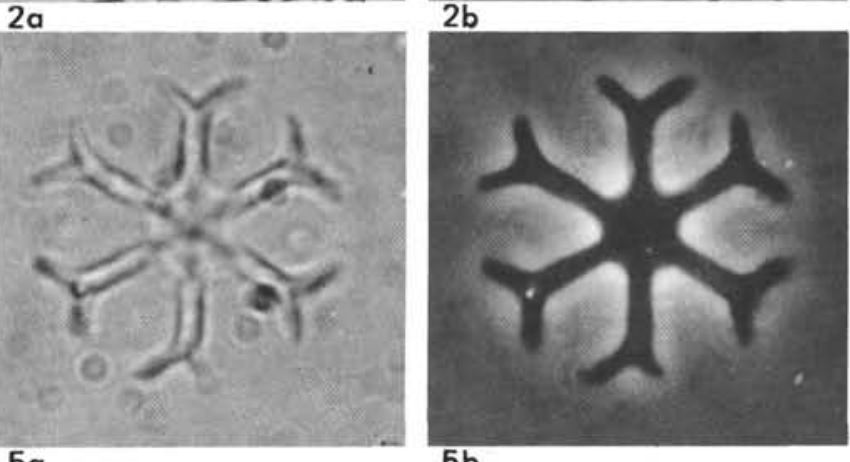

$5 a$

$5 b$
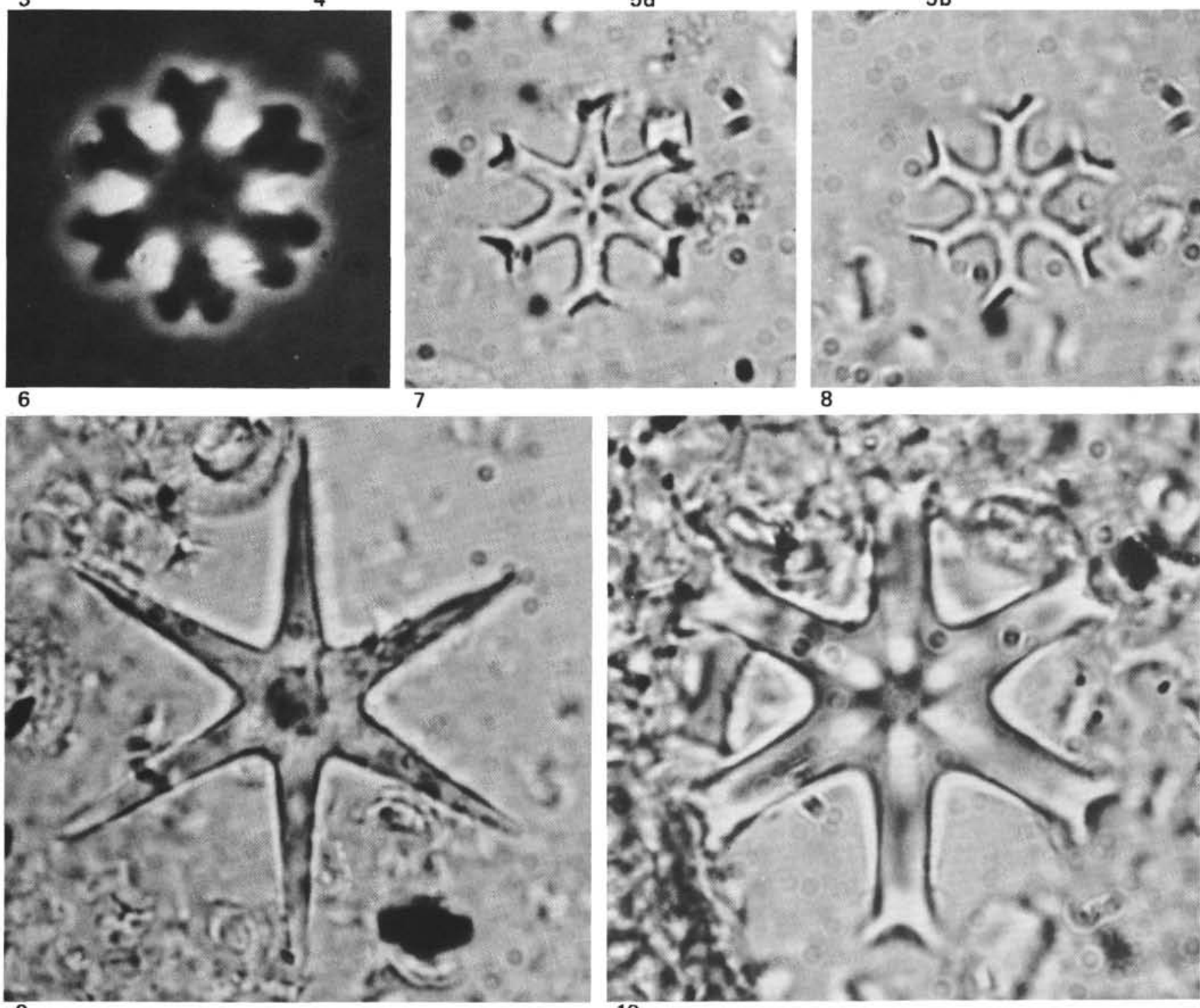


\section{PLATE 10}

Figure 1

Figure 3

Figure 5

Figure 6

Figure 7

Figure 8

Figure 9

Figure 10

Figure 12
Cruciplacolithus tenuis (Stradner). Sample 364-10$5,9-10 \mathrm{~cm}$.

1a. Transmitted light.

lb. Cross-polarized light $(\times 2800)$.

Campylosphaera eodela Bukry. Sample 364-9, CC.

2a. Phase contrast.

2b. Cross-polarized light $(\times 2800)$.

Campylosphaera dela (Bramlette and Sullivan). Sample 364-8-1, 9-10 cm.

3a. Phase contrast.

3 b. Cross-polarized light $(\times 2800)$.

Cyclolithella robusta (Bramlette and Sullivan). Sample $364-10-1,39-40 \mathrm{~cm}$.

$4 \mathrm{a}$. Phase contrast.

4b. Cross-polarized light $(\times 2800)$.

Markalius inversus (Deflandre).

Cross-polarized light $(\times 2800)$. Sample 364-10-2, 9$10 \mathrm{~cm}$.

Toweius craticulus Hay and Mohler.

Cross-polarized light $(\times 2800)$. Sample 364-9, CC.

Chiasmolithus californicus (Sullivan). Sample 36410-2, 9-10 cm.

7a. Phase contrast.

7b. Cross-polarized light $(\times 2800)$.

Heliolithus kleinpellii Sullivan. Sample 364-10-1, $39-40 \mathrm{~cm}$.

8a. Phase contrast.

8 b. Cross-polarized light $(\times 2800)$.

Coccolithus crassus Bramlette and Sullivan. Sample 364-8-4, 9-10 cm.

9a. Phase contrast.

9b. Cross-polarized light $(\times 2800)$.

Ellipsolithus macellus (Bramlette and Sullivan). Sample 364-9-4, 9-10 cm.

10a. Phase contrast.

10b. Cross-polarized light $(\times 2400)$.

Figure 11 Coccolithus cribellum Bramlette and Sullivan. Sample 364-8-3, 9-10 cm.

11a. Transmitted light.

11b. Phase contrast.

11c. Cross-polarized light $(\times 2800)$.

Coccolithus magnicrassus Bukry. Sample 364-8-4, 9-10 cm.

12a. Transmitted light.

12b. Phase contrast.

12c. Cross-polarized light $(\times 2800)$.

(see p. 622) 
PLATE 10
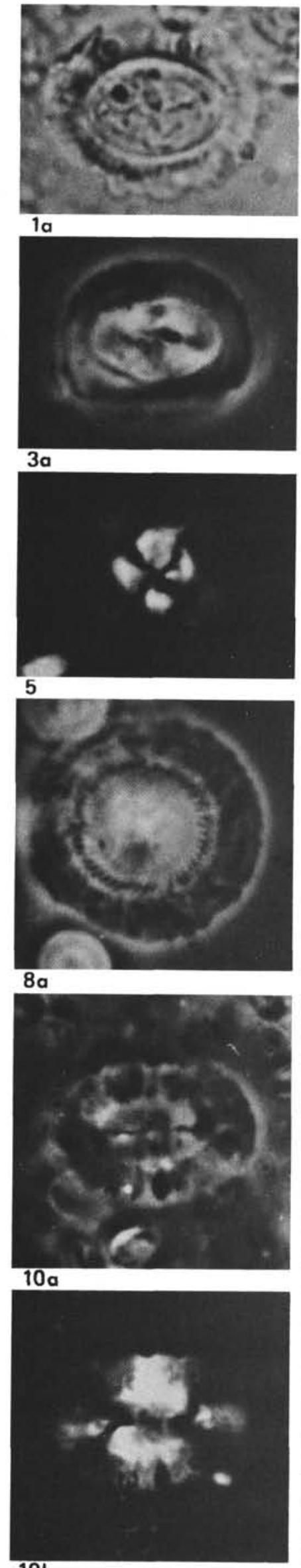
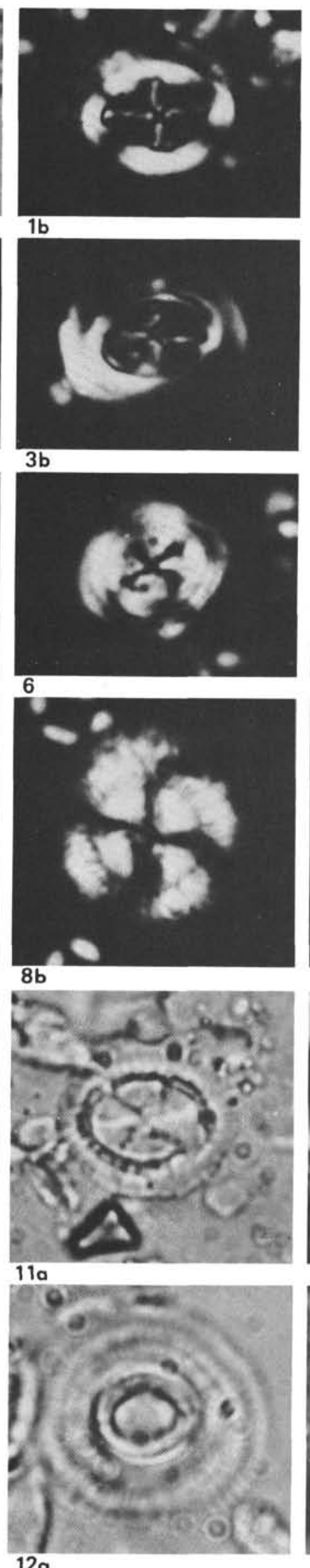

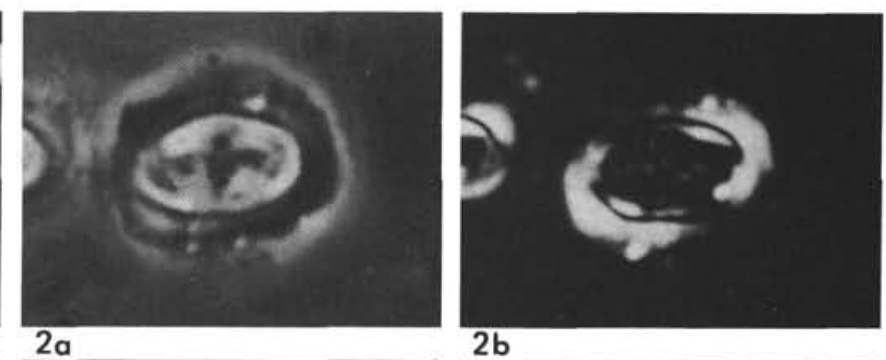

$2 a$
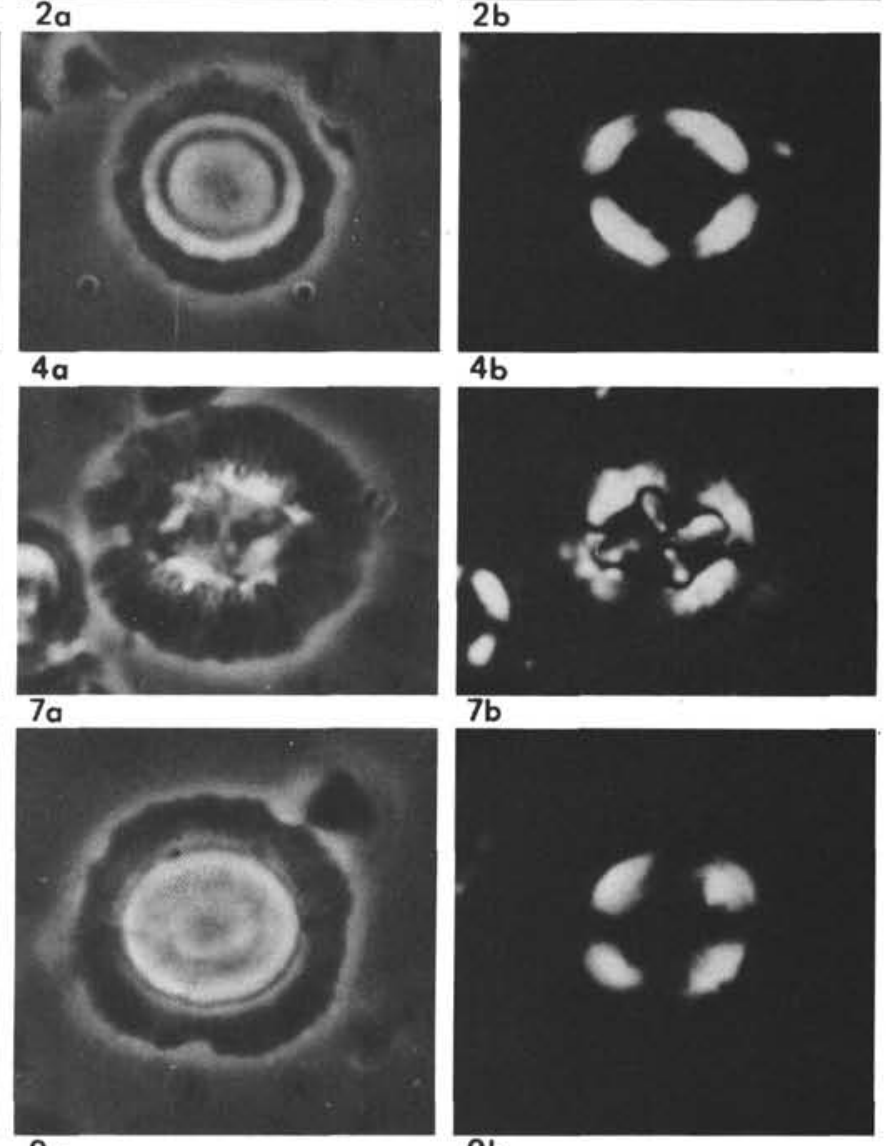

$9 a$

$7 \mathrm{~b}$

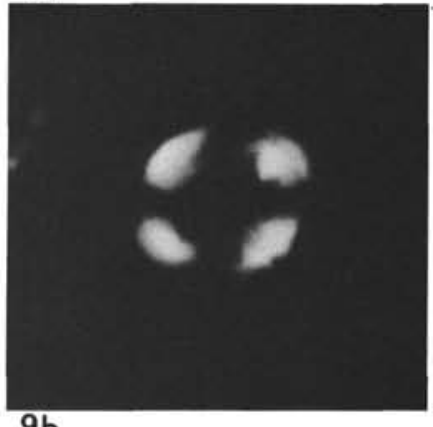

$9 b$

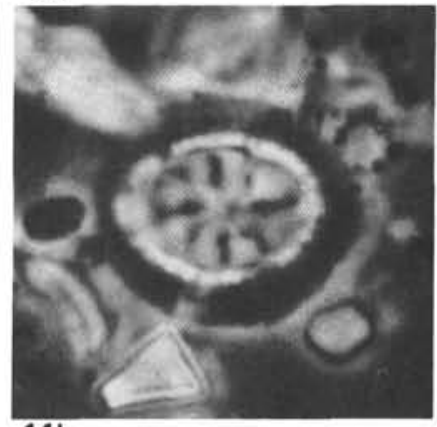

$11 \mathrm{~b}$

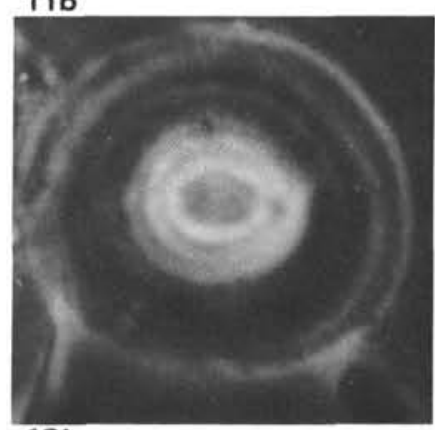

$12 b$

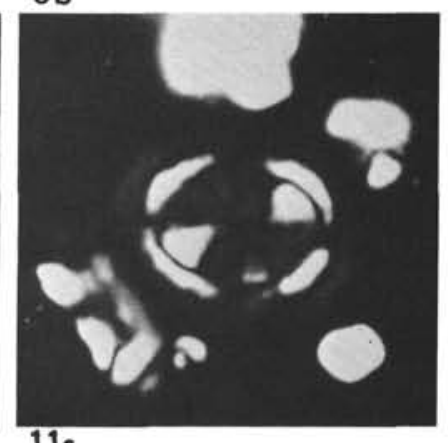

$11 \mathrm{c}$

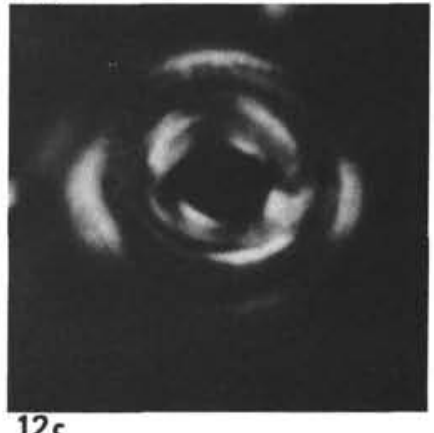

$12 \mathrm{c}$ 


\section{PLATE 11}

Figures 1, 2 Discoasteroides kuepperi (Stradner).

1a, 2a. Transmitted light.

1b, 2b. Cross-polarized light $(\times 2800)$.

1. Sample $364-9-1,17-18 \mathrm{~cm}$.

2. Sample $364-9-2,9-10 \mathrm{~cm}$.

Figure 3 Discoaster sp. 1.

Transmitted light $(\times 2800)$. Sample $364-9, \mathrm{CC}$.

Figure 4 Discoaster multiradiatus Bramlette and Riedel. Sample 364-9-1, 17-18 cm.

4a. Transmitted light.

4b. Phase contrast $(\times 2800)$.

Figures 5,6 Discoaster diastypus Bramlette and Sullivan.

5, 6a. Transmitted light.

6b. Phase contrast $(\times 2800)$.

5. Sample 364-9-1, $17-18 \mathrm{~cm}$.

6. Sample $364-9-2,9-10 \mathrm{~cm}$.

Figure 7 Chiasmolithus grandis (Bramlette and Riedel). Sample 364-8-4, 9-10 cm.

7a. Transmitted light.

7b. Cross-polarized light $(\times 2800)$.

(see p. 624) 
PLATE 11
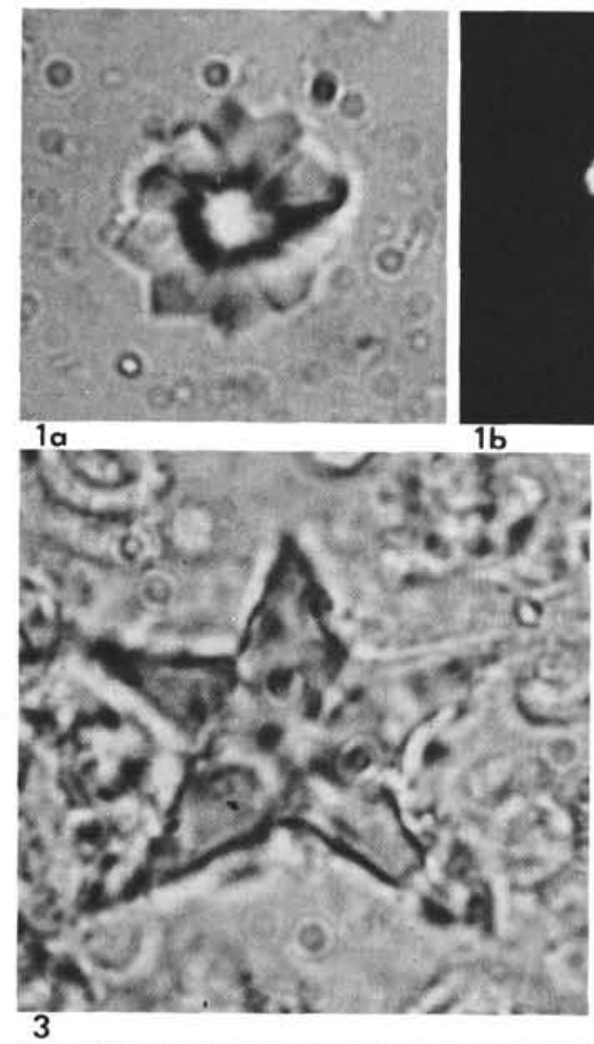

3
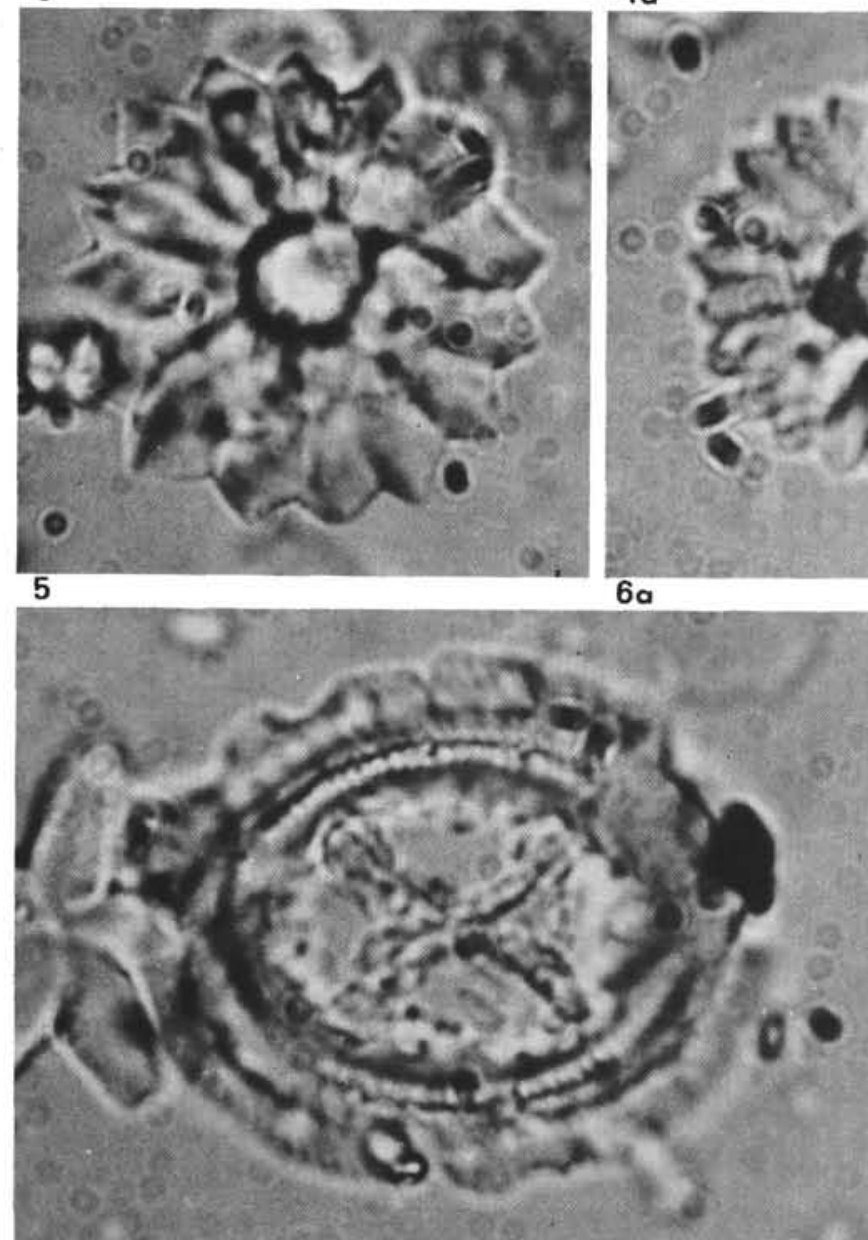

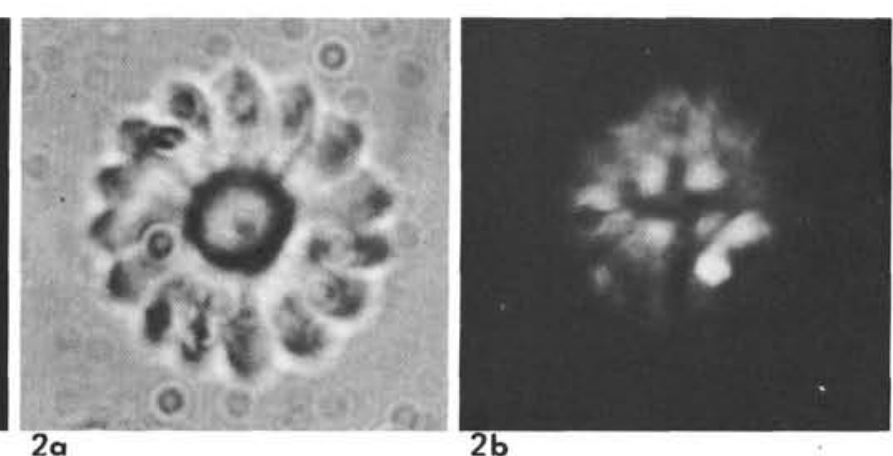

$2 a$
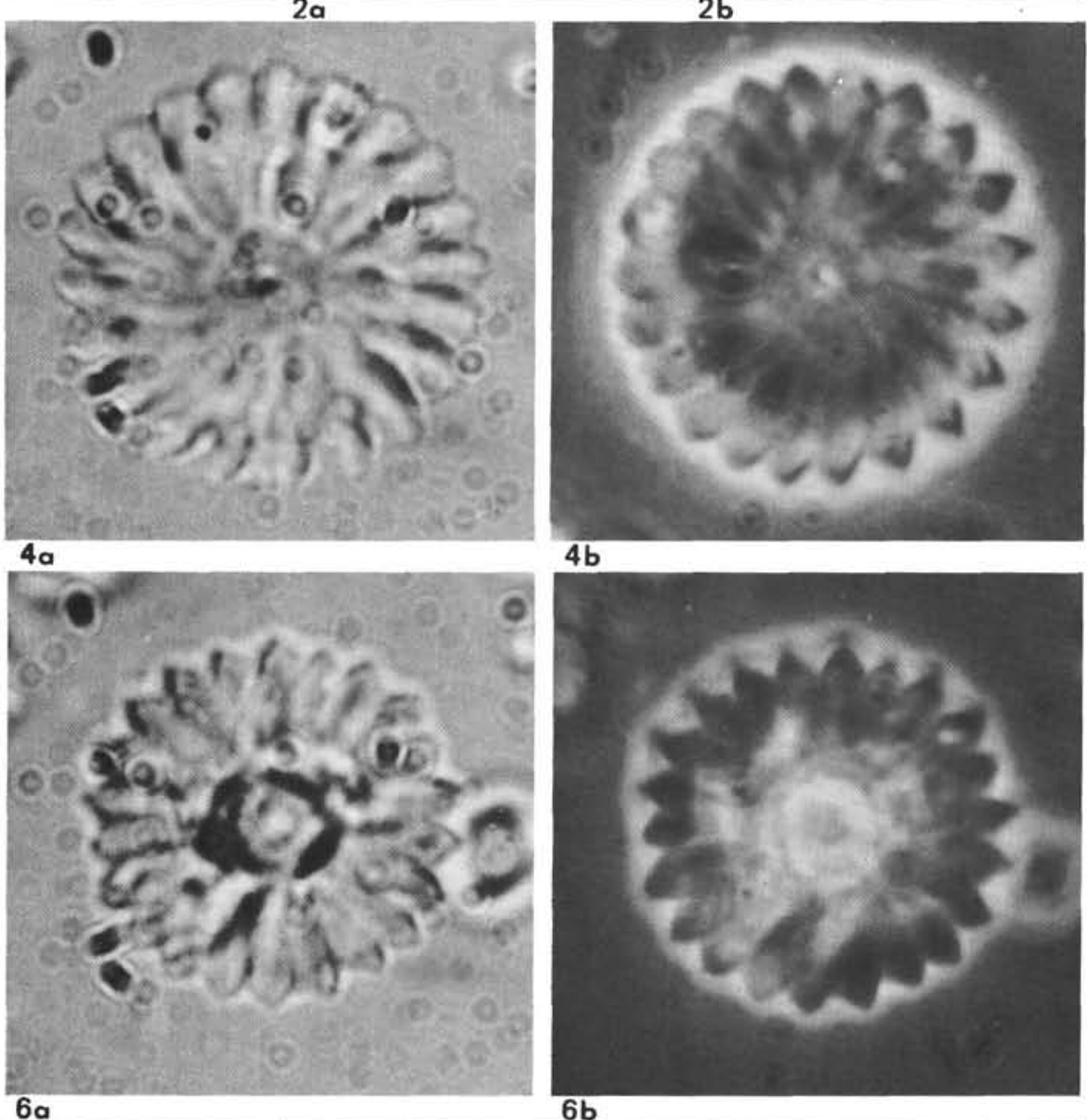

$6 b$
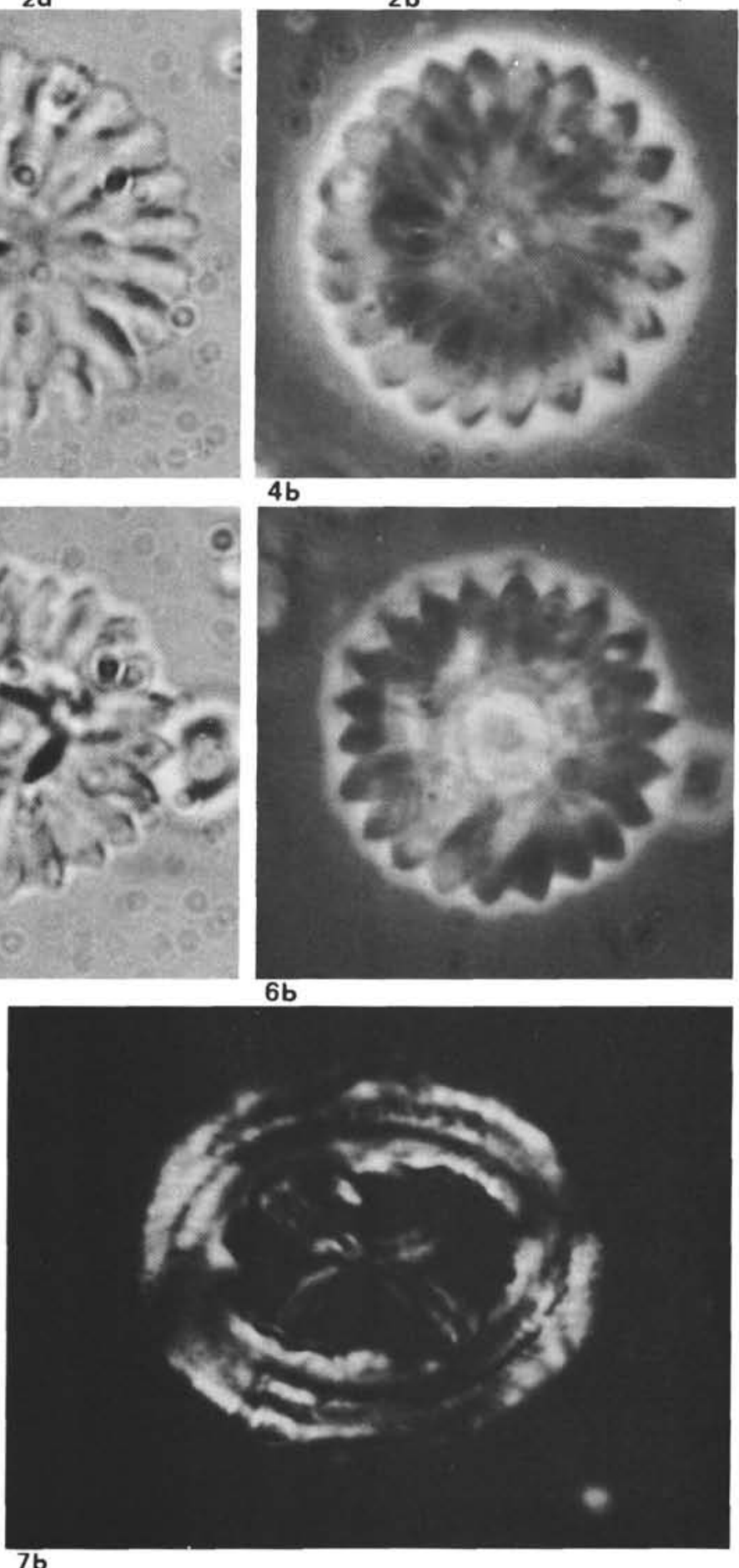


\section{PLATE 12}

Figure $1 \quad$ Fasciculithus janii Perch-Nielsen. Sample 364-10-2, 9-10 cm.

1a. Transmitted light.

lb, 1c. Cross-polarized light $(\times 2800)$.

Figure 2 Sphenolithus spiniger Bukry. Sample 364-8-1, 9-10 $\mathrm{cm}$.

2a. Phase contrast.

2b. Long axis $0^{\circ}$ to crossed nicols.

2c. Long axis $45^{\circ}$ to crossed nicols $(\times 2800)$.

Figures 3, 6 Fasciculithus pileatus Bukry. Sample 364-10-2, 9$10 \mathrm{~cm}$.

3a, 3b. Transmitted light.

3 c, 6, Cross-polarized light $(\times 2800)$.

Figures 4, 5 Sphenolithus orphanknollii Perch-Nielsen. Sample 364-8-3, 9-10 cm.

5a. Transmitted light.

$4 \mathrm{a}, 5 \mathrm{~b}$. Phase contrast.

$4 \mathrm{~b}, 5 \mathrm{c}$. Long axis $45^{\circ}$ to crossed nicols.

$4 \mathrm{c}, 5 \mathrm{~d}$. Long axis $0^{\circ}$ to crossed nicols $(\times 2800)$.

Figure 7 Fasciculithus involutus Bramlette and Sullivan. Sample 364-10-1, 39-40 cm.

7a. Transmitted light.

7b. Long axis $0^{\circ}$ to crossed nicols.

7c. Long axis $45^{\circ}$ to crossed nicols $(\times 2800)$.

Figure $8 \quad$ Nannotetrina cristata (Martini).

Transmitted light $(\times 2800)$. Sample $364-7, \mathrm{CC}$.

Figures 9-11 Discoaster sp. 1. Sample 364-9, CC.

9 , 10. Transmitted light $(\times 2800)$.

11. Transmitted light $(\times 2400)$.

Figure 12 Discoaster tanii nodifer Bramlette and Riedel. Transmitted light $(\times 2800)$. Sample 364-7, CC.

Figures 13-15 Rhomboaster cuspis Bramlette and Sullivan. Sample 364-9-1, 17-18 cm.

13, 14. Transmitted light $(\times 2800)$.

15. Transmitted light $(\times 2400)$.

(see p. 626) 
PLATE 12

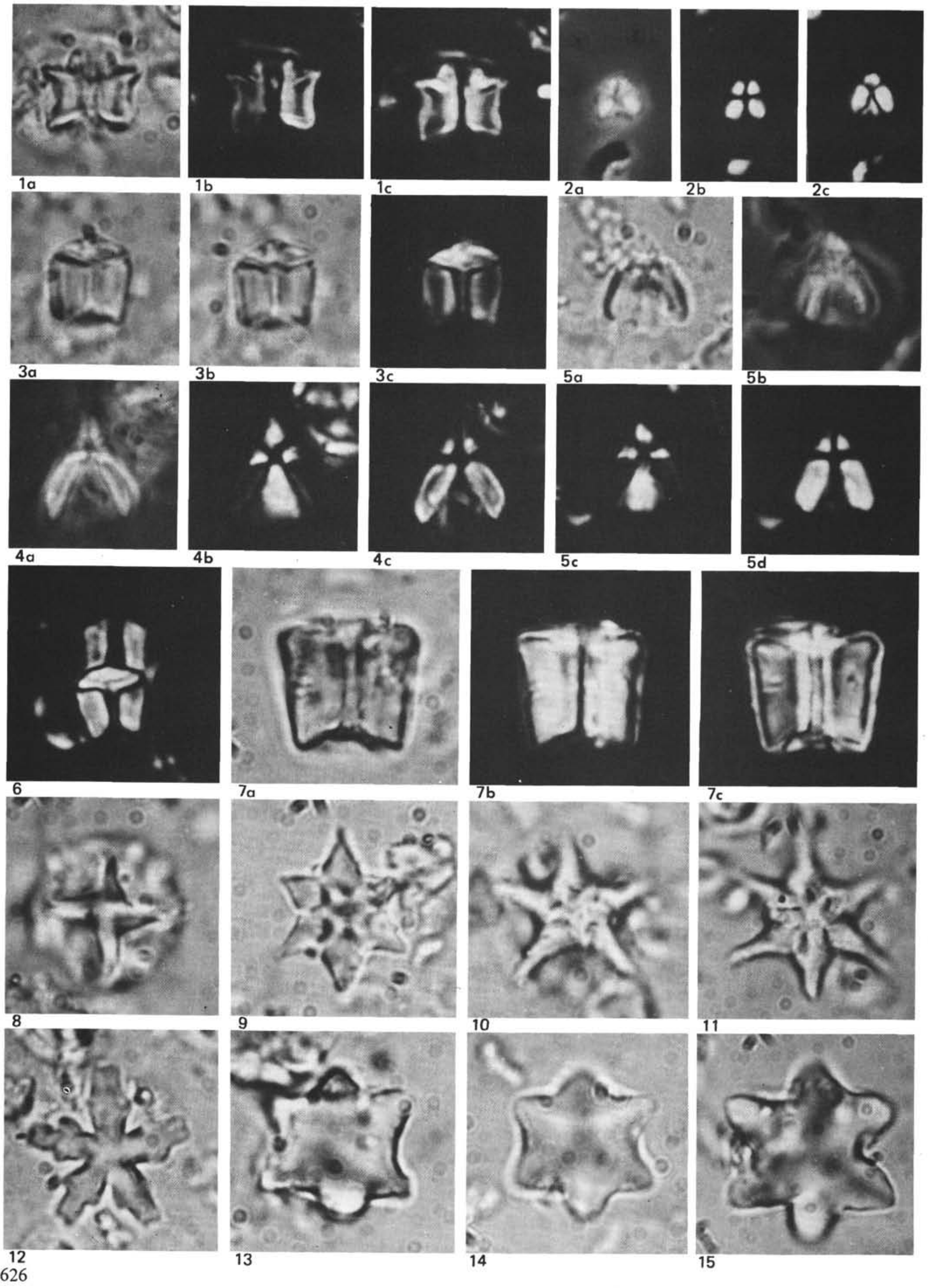




\section{PLATE 13}

Figure $1 \quad$ Microrhabdulus decoratus Deflandre. Sample 36414-1, $95-96 \mathrm{~cm}$.

1a. Transmitted light.

1b, 1c. Cross-polarized light $(\times 2800)$.

Figure 2 Microrhabdulus stradneri Bramlette and Martini. Cross-polarized light $(\times 2800)$. Sample 363-19-2, $58-60 \mathrm{~cm}$.

Figure 3 Tetralithus gothicus Deflandre.

Cross-polarized light $(\times 2800)$. Sample 364-14-3, 9 $10 \mathrm{~cm}$.

Figures 4, 6 Tetralithus premurus Bukry. Sample 364-11, CC. 6a. Transmitted light.

4, 6b. Cross-polarized light $(\times 2800)$.

Figures 5, 11-13 Micula mura (Martini). Sample 363-19-2, 58-60 $\mathrm{cm}$.

5a. Phase contrast.

5 b. Cross-polarized light $(\times 2800)$.

11-13. Scanning electron micrographs $(\times 5000)$.

Figures 7, 14 Micula staurophora (Gardet).

7a. Transmitted light. 7b. Cross-polarized light (×2800). Sample 364-11, CC.

14. Scanning electron micrographs $(\times 5000)$. Sample 363-18-2, $45-46 \mathrm{~cm}$.

Figures 8, 15, 16 Lithraphidites quadratus Bramlette and Martini.

8a. Phase contrast. 8b. Cross-polarized light (×2800). Sample 363-19-2, 58-60 cm.

15, 16. Scanning electron micrographs $(\times 5000)$. Sample 363-18-2, 45-48 cm.

Figures 9, 10 Distal part of the stem of Prediscosphaera cretacea (Arkhangelsky). Scanning electron micrograph (×6000). Sample 363-19-2, 58-60 cm.

(see p. 628) 
PLATE 13
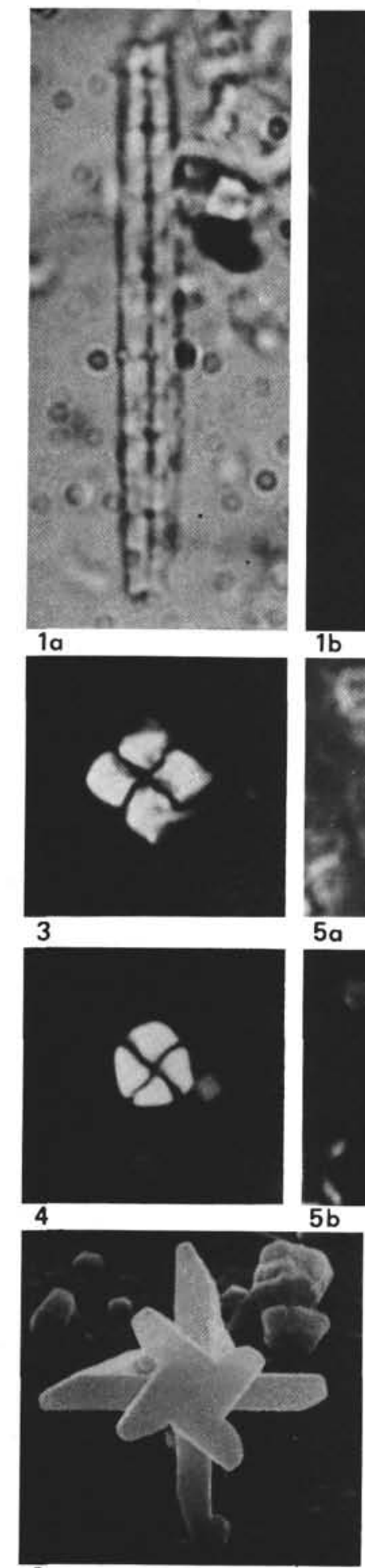

9

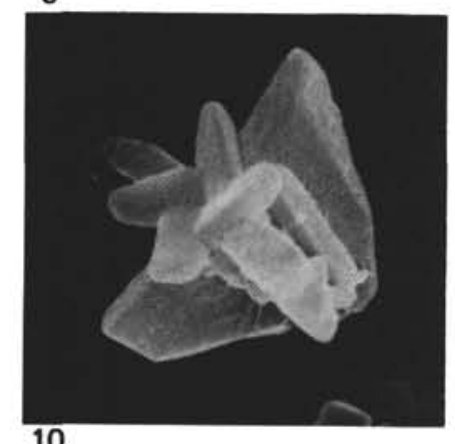

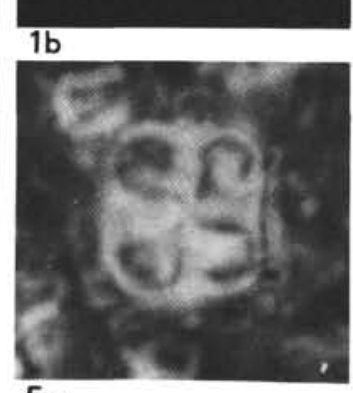

$5 a$
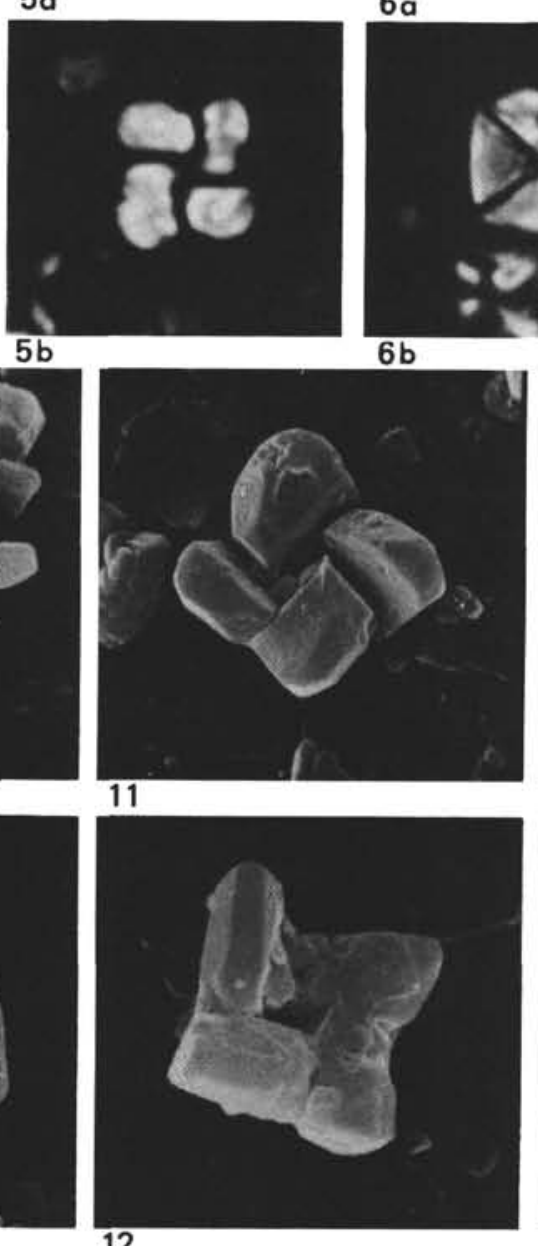

$6 a$
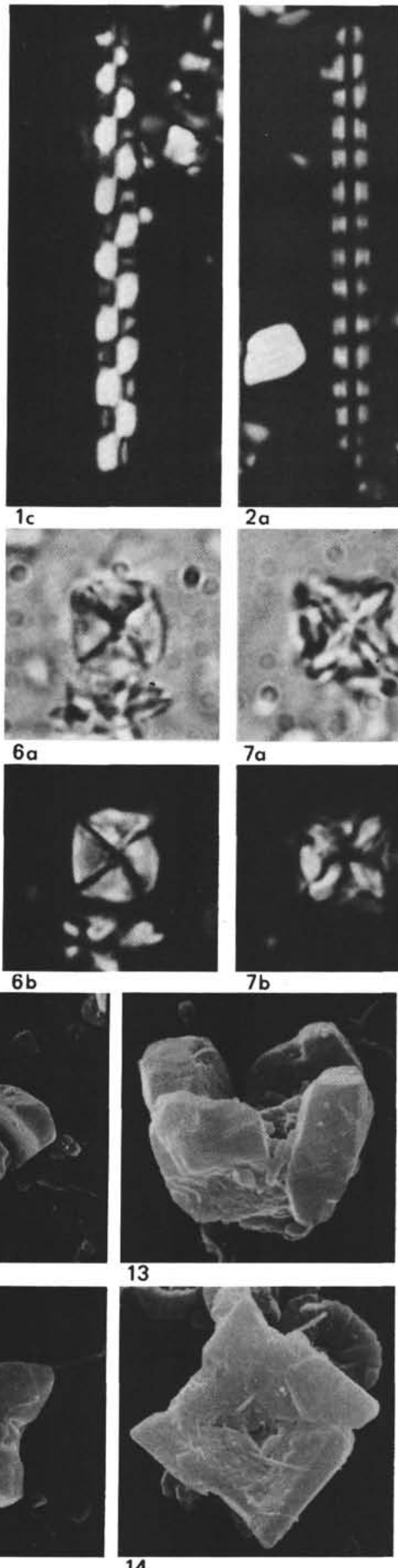

$7 a$

$7 b$

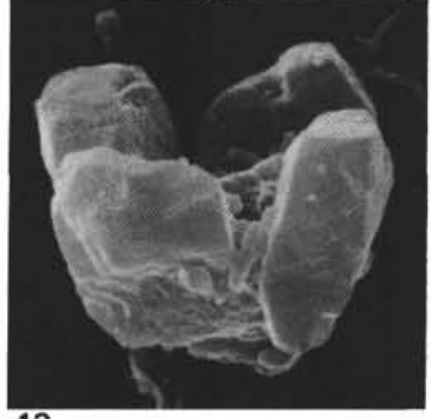

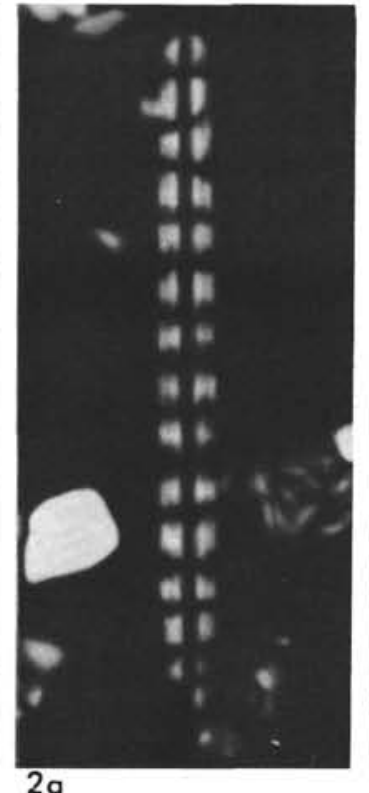
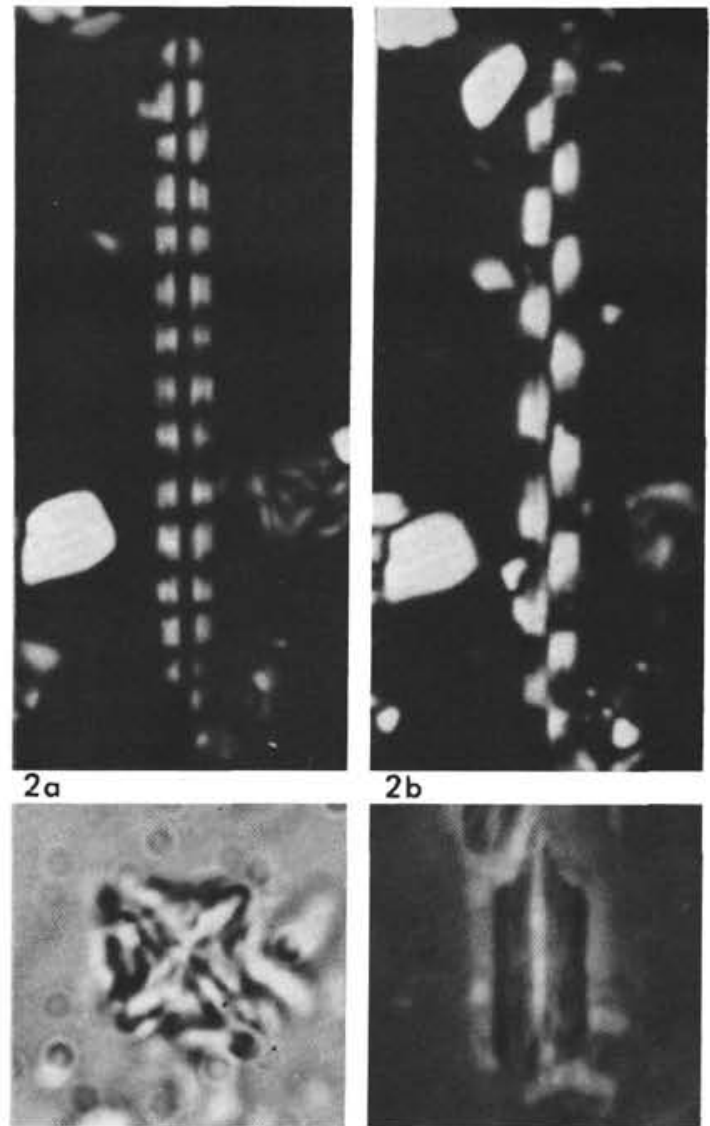

$2 b$

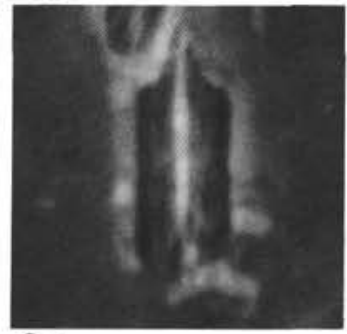

$8 a$
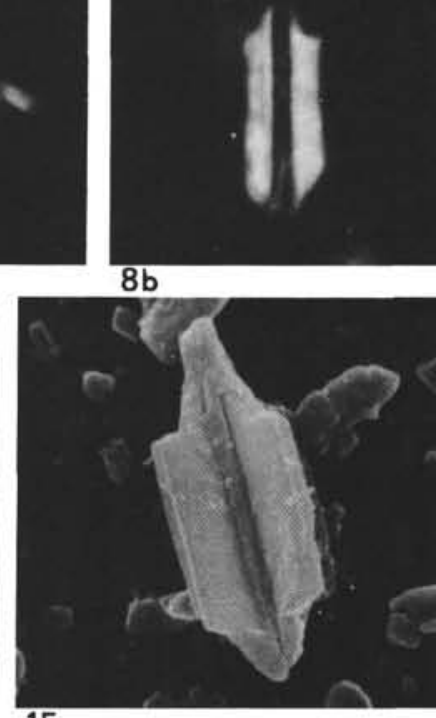

15

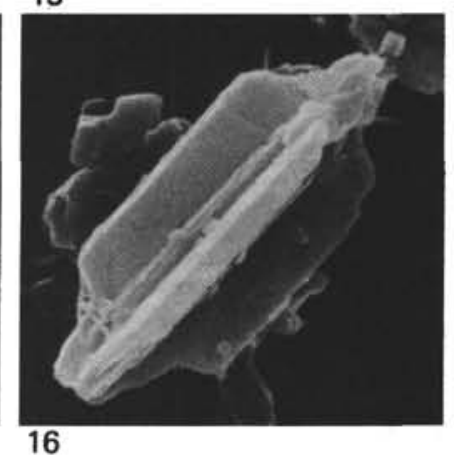




\section{PLATE 14}

Figure 1 Cribrosphaerella ehrenbergii (Arkhangelsky). Sample 364-14-4, 9-10 cm.

1a. Transmitted light.

1b. Phase contrast.

1c. Cross-polarized light $(\times 2800)$.

Figure 2 Cruciellipsis chiastia (Worsley). Cross-polarized light (×3500). Sample 364-40-2, 17-18 cm.

Figures 3,6 Parhabdolithus asper (Stradner).

3a. Phase contrast. 3b. Cross-polarized light $(\times 2800)$. Sample 364-32, CC.

6a. Phase contrast. 6b. Cross-polarized light $(\times 3500)$. Sample 364-39, CC.

Figure 4

Broinsonia enormis (Shumenko). Sample 364-20-2, $9-10 \mathrm{~cm}$.

4a. Phase contrast.

4b. Cross-polarized light $(\times 2800)$.

Figure 5 Tranolithus exiguus Stover. Sample 364-23-2, 9-10 $\mathrm{cm}$.

5a. Phase contrast.

5 b. Cross-polarized light $(\times 2800)$.

Figure $7 \quad$ Manivitella pemmatoidea (Deflandre). Sample 364$34-3,87-88 \mathrm{~cm}$.

7a. Phase contrast.

7b. Cross-polarized light $(\times 2800)$.

Figure 8 Cretarhabdus coronadventis Reinhardt. Sample 364-35-1, 16-17 cm.

8 a. Phase contrast.

8 b. Cross-polarized light $(\times 2800)$.

Figure 9 Microrhabdulus stradneri Bramlette and Martini. Cross-polarized light $(\times 2800)$. Sample 363-19-2, $58-60 \mathrm{~cm}$.

Figure 10 Broinsonia parca (Stradner). Sample 364-14-1, 95$96 \mathrm{~cm}$.

10a. Phase contrast.

10b. Cross-polarized light $(\times 2800)$.

Figure 11 Gartnerago obliquum (Stradner). Sample 364-20-2, 9-10 cm.

11a. Phase contrast.

11b. Cross-polarized light $(\times 2800)$.

Figure 12 Kamptnerius magnificus Deflandre. Sample 36420-2, 9-10 cm.

12a. Transmitted light.

12b. Phase contrast.

12c. Cross-polarized light $(\times 2800)$.

(see p. 630) 
PLATE 14
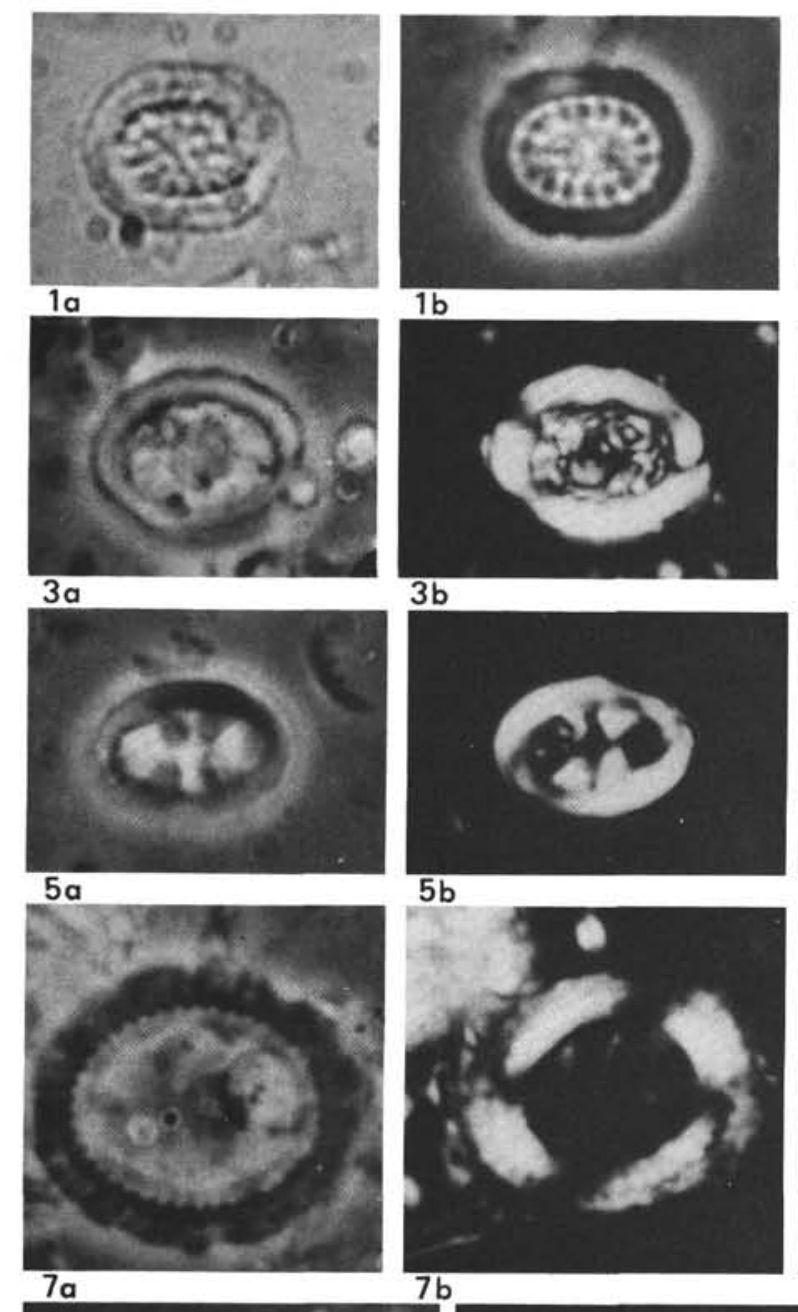

$7 b$
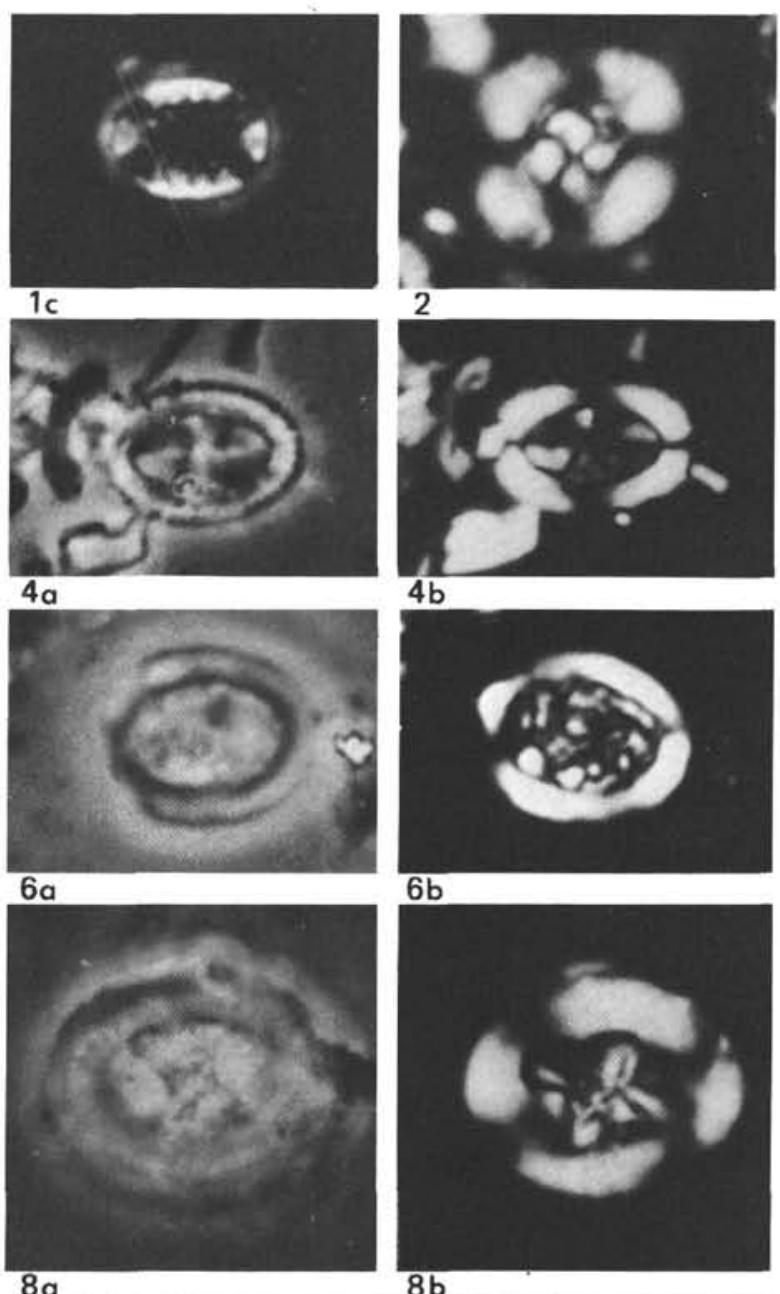

$6 b$
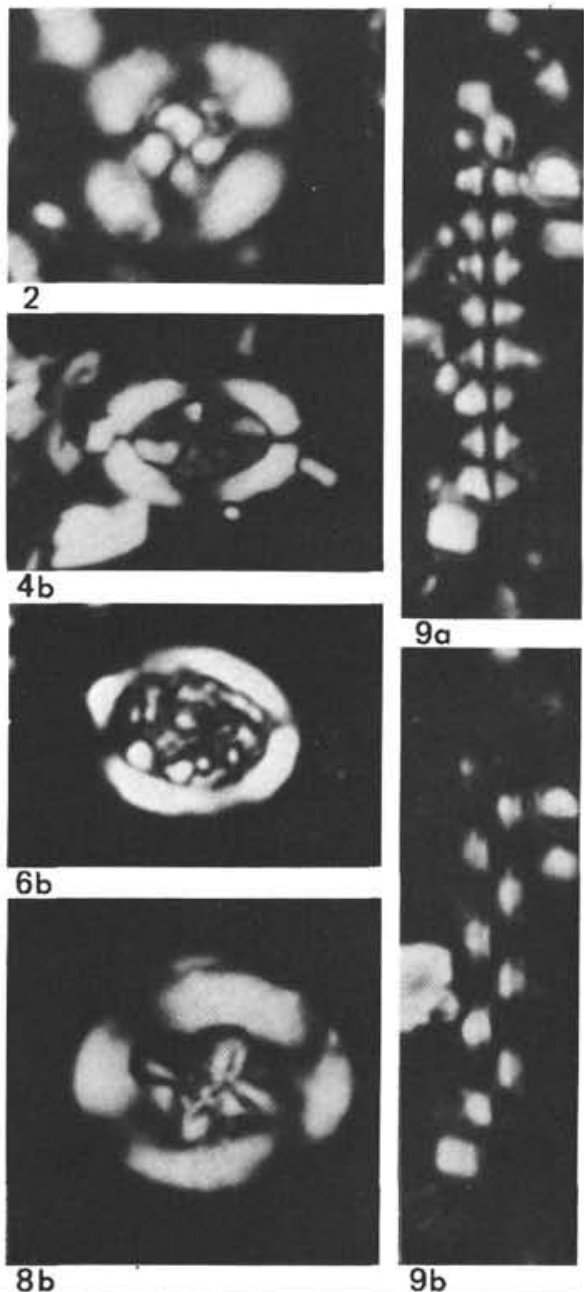

$9 \mathrm{~b}$

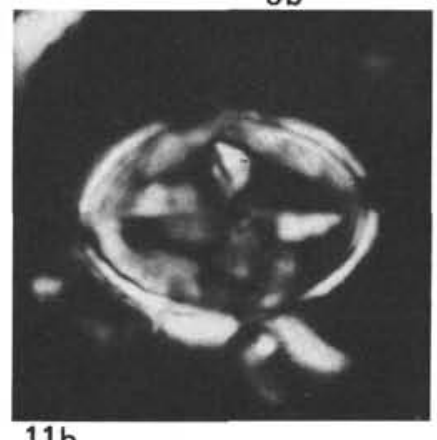

$11 a$

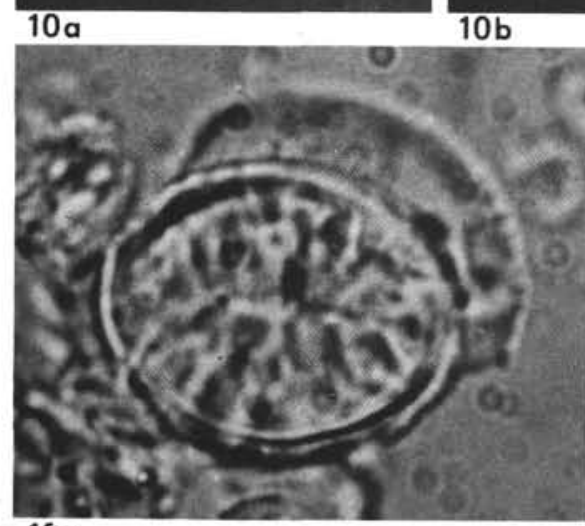

$12 a$
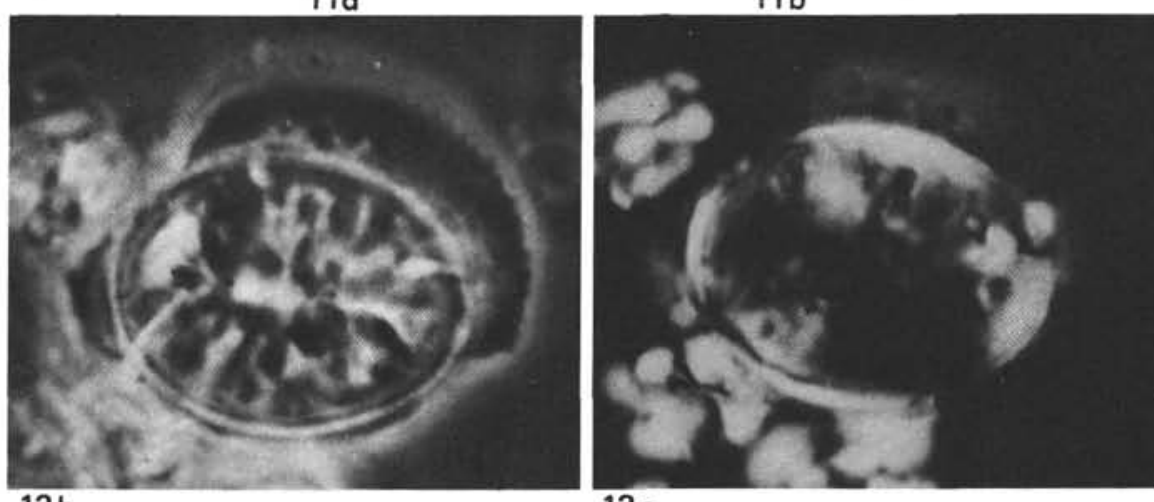

$12 c$ 


\section{PLATE 15}

Figure 1 Biscutum constans (Gorka). Sample 364-35-2, 78-79 $\mathrm{cm}$.

1a. Transmitted light.

1b. Phase contrast.

1c. Cross-polarized light $(\times 2800)$.

Figure 2 Braarudosphaera africana Stradner. Sample 364-34-3, 67-68 cm.

2a. Transmitted light.

2b. Phase contrast.

2c. Cross-polarized light $(\times 2800)$.

Figure 3 Broinsonia lata (Noel). Sample 364-35-1, 16-17 cm.

3a. Phase contrast.

3b. Cross-polarized light $(\times 3500)$.

Figure 4 Reinhardtites fenestratus (Worsley). Sample 364-35-1, 16-17 cm. 4a, 4b. Phase contrast.

$4 \mathrm{c}, 4 \mathrm{~d}$. Cross-polarized light $(\times 3500)$.

Figures 5,9 Prediscosphaera cretacea (Arkhangelsky). Sample 364-31-1, 60-61 cm.

5, 9c. Cross-polarized light.

9a. Transmitted light.

9b. Phase contrast $(\times 3500)$.

Figure $6 \quad$ Tranolithus orionatus $($ Reinhardt). Cross-polarized light $(\times 3500)$. Sample 364-32, CC.

Figure $7 \quad$ Vagalapilla matalosa (Stover). Sample 364-32, CC.

7a. Phase contrast.

7b. Cross-polarized light $(\times 3500)$.

Figures 8,16 Parhabdolithus splendens (Deflandre).

8 a. Phase contrast. 8 b. Cross-polarized light $(\times 3500)$. Sample 364-40$2,30-31 \mathrm{~cm}$.

16a. Transmitted light. 16b. Phase contrast. 16c. Cross-polarized light (×2800). Sample 364-31-1, 60-61 cm.

Figures 10,11 Tetralithus trifidus (Stradner). Sample 364-14-3, 9-10 cm.

10, 11a. Phase contrast.

11b. Cross-polarized light $(\times 2800)$.

Figure 12 Watznaueria ovata Bukry. Sample 364-35-1, 16-17 cm.

12a. Phase contrast.

12b. Cross-polarized light $(\times 2800)$.

Figure 13 Tegumentum stradneri Thierstein. Sample $364-40-2,30-31 \mathrm{~cm}$.

13a. Phase contrast.

13b, 13c. Cross-polarized light $(\times 3500)$.

Figure 14 Ahmuellerella octoradiata (Gorka). Sample 364-14-3, 9-10 cm.

$14 \mathrm{a}, 14 \mathrm{~b}$. Phase contrast.

$14 \mathrm{c}$. Cross-polarized light $(\times 2800)$.

Figure 15 Ahmuellerella sp. aff. A. octoradiata (Gorka). Sample 364-32-4, 91-92 cm.

15a. Transmitted light.

15b. Phase contrast.

15c. Cross-polarized light $(\times 3500)$.

Figure 17 Eiffellithus anceps (Gorka). Sample 364-14-4, 9-10 cm.

17a. Phase contrast.

$17 \mathrm{~b}, 17 \mathrm{c}$. Cross-polarized light $(\times 2800)$.

(see p. 632) 
PLATE 15
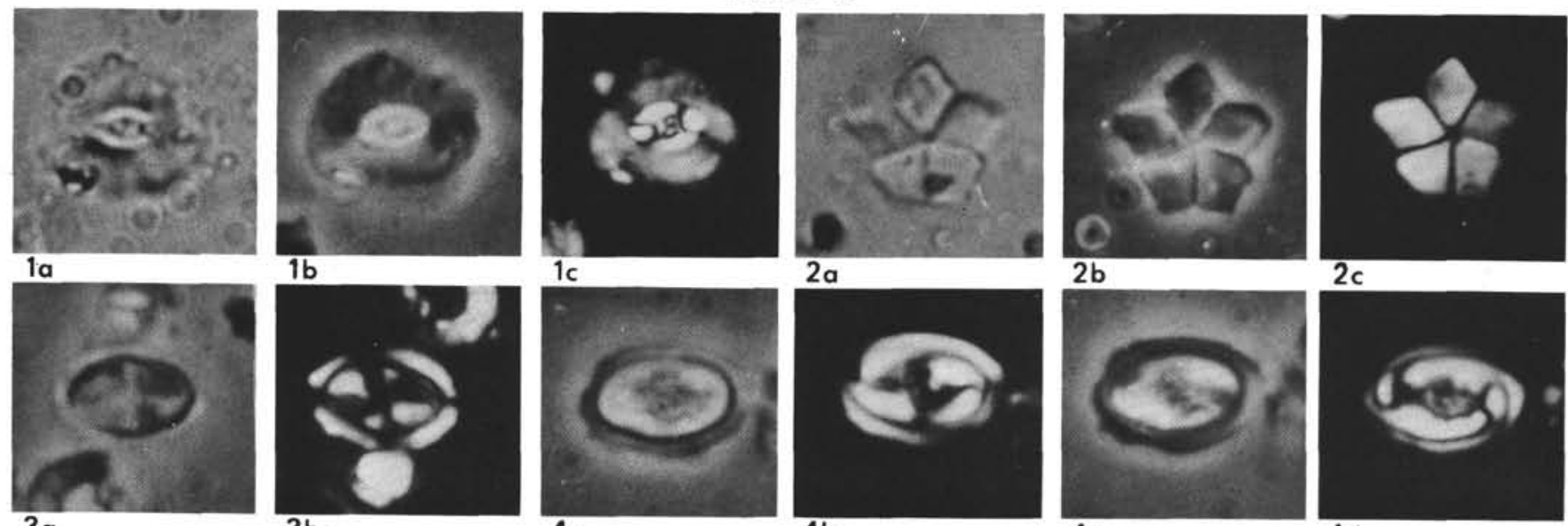
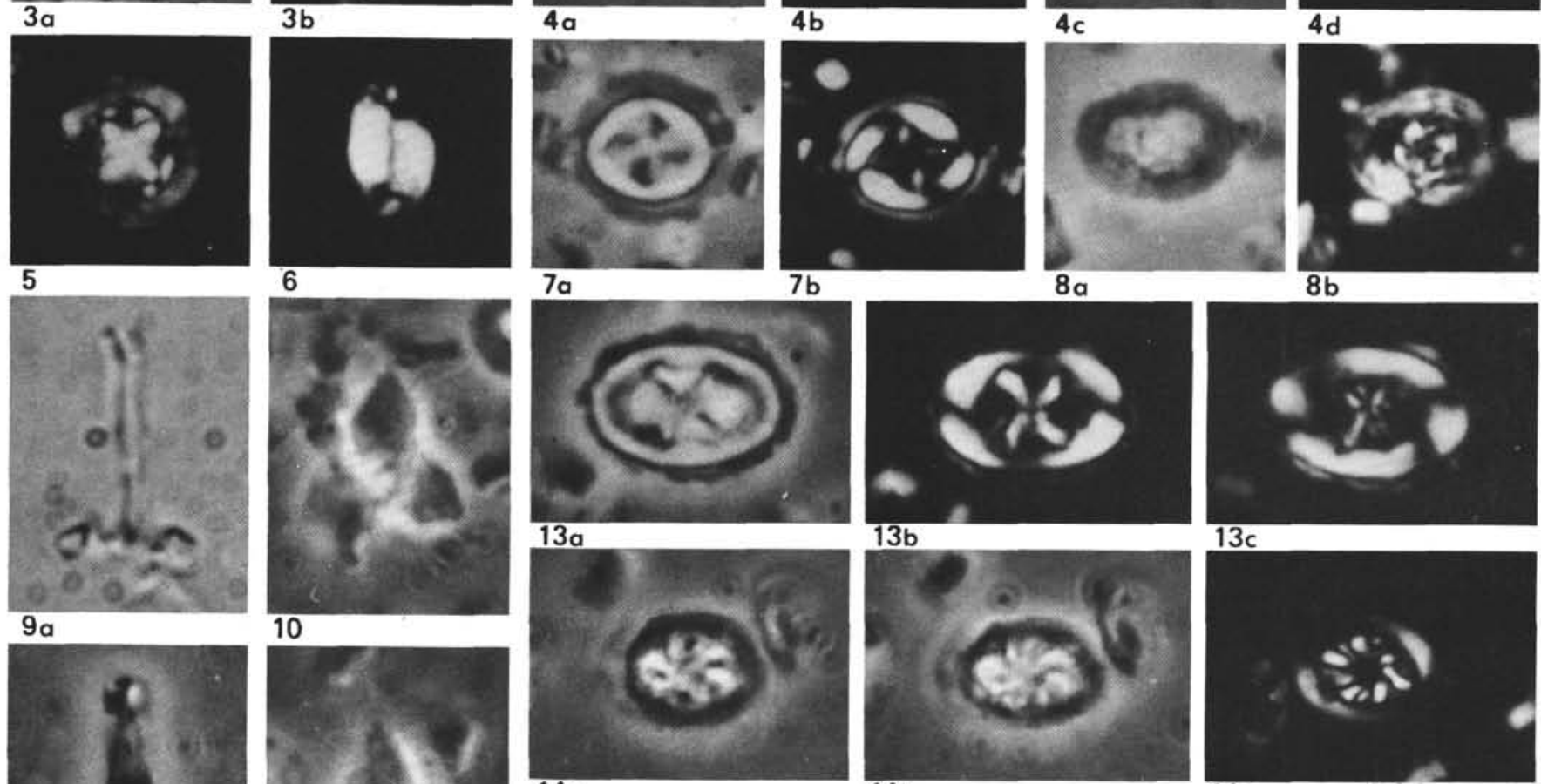

$13 \mathrm{~b}$
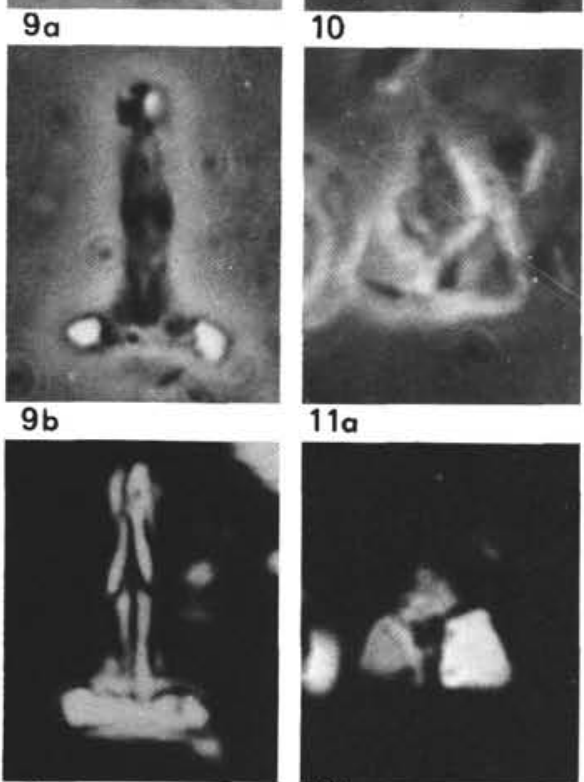

$9 c$

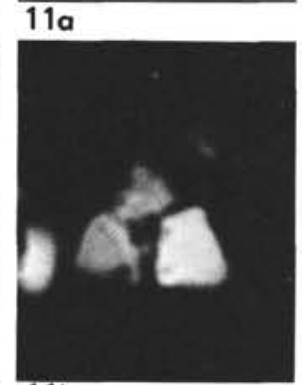

$11 \mathrm{~b}$
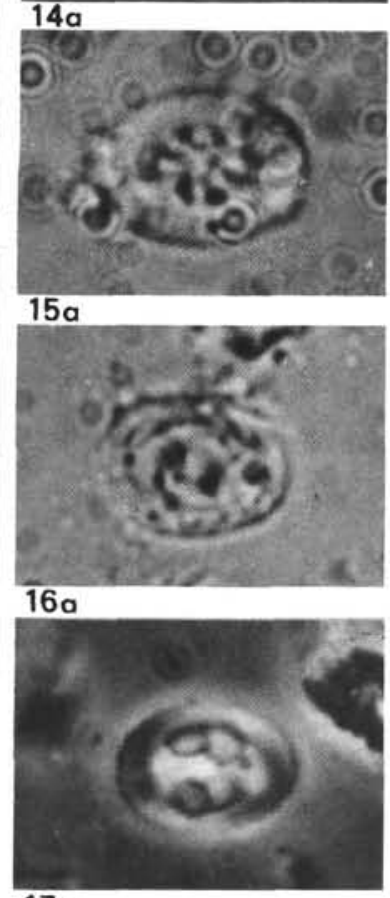

$17 a$

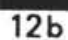

28

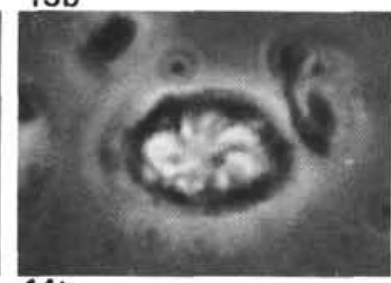

$14 b$

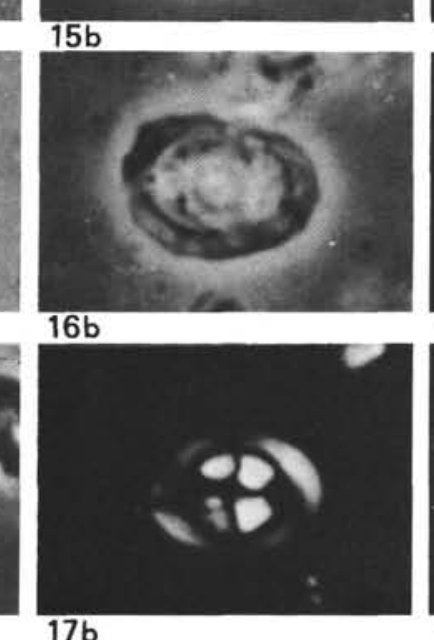

$17 b$

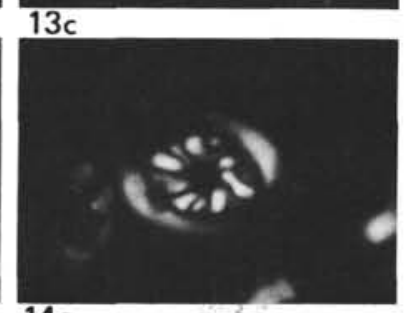

$14 c$
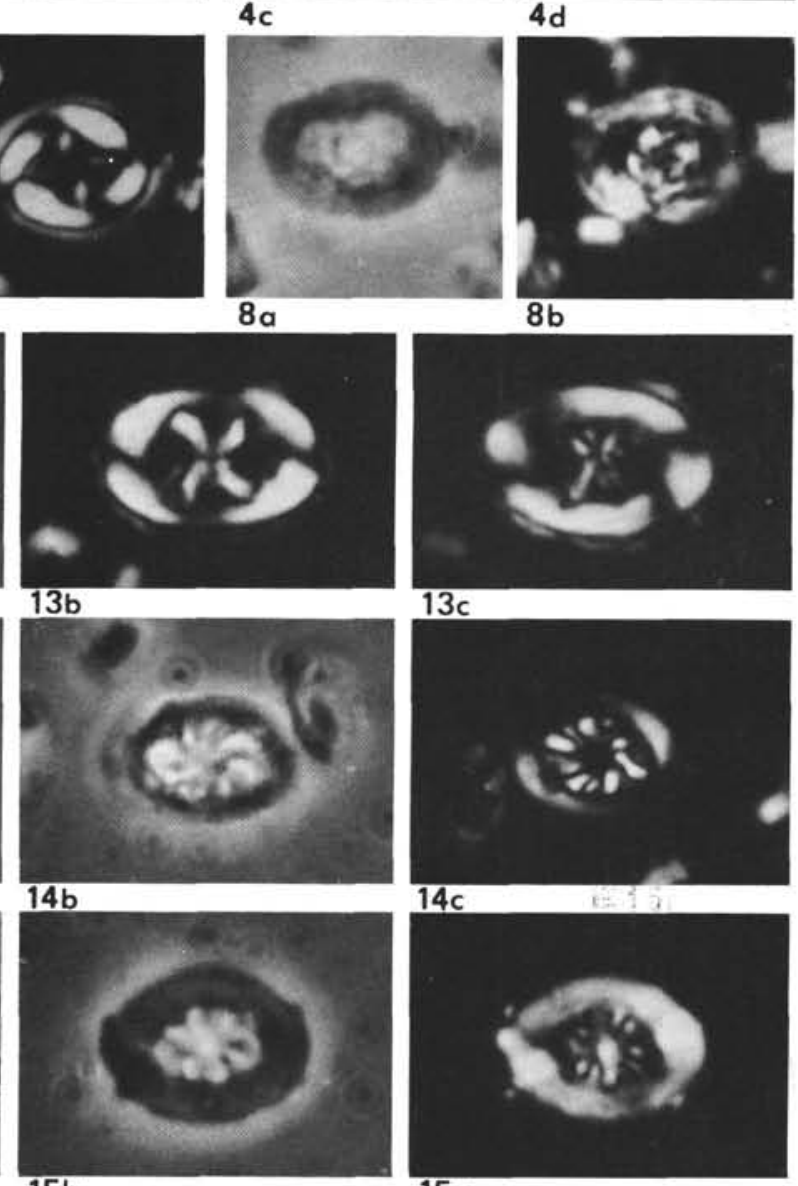

$15 c$

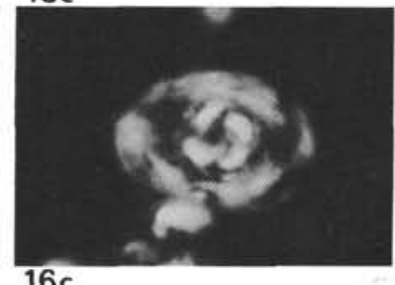

$16 \mathrm{c}$

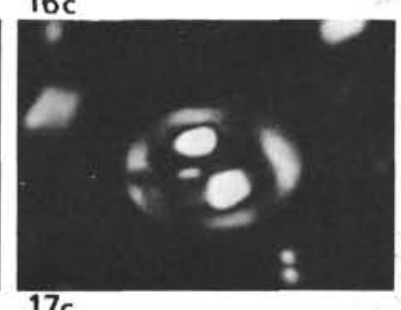

17c 


\section{PLATE 16}

Figure 1 Lithastrinus grillii Stradner. Sample 364-23-2, 9-10 $\mathrm{cm}$.

la. Transmitted light.

lb. Phase contrast.

1c. Cross-polarized light $(\times 2800)$.

Figure 2 Cretarhabdus crenulatus Bramlette and Martini. Sample 364-40-2, 30-31 cm.

2a. Phase contrast.

2b. Cross-polarized light $(\times 2800)$.

Figures 3-6 Nannoconus truittii Brönnimann.

3 , 4, 5a. Transmitted light.

5 b, 6. Cross-polarized light $(\times 2800)$.

3-5. Sample 364-31-1, 60-61 cm.

6. Sample $364-34-3,87-88 \mathrm{~cm}$.

Figures 7, $9 \quad$ Lithastrinus floralis Stradner. Sample 364-34-3, 87$88 \mathrm{~cm}$.

7a, 9a. Transmitted light.

7b. Phase contrast.

7c, 9b. Cross-polarized light $(\times 2800)$.

Figure $8 \quad$ Watznaueria barnesae Black. Sample 364-39, CC. 8a. Phase contrast.

8 b. Cross-polarized light $(\times 3500)$.

Figure 10 Parhabdolithus embergeri (Noel). Sample 364-34-3, $87-88 \mathrm{~cm}$.

10a. Transmitted light.

10b. Phase contrast.

10c. Cross-polarized light $(\times 2800)$.

Figures 11, 12 Rucinolithus sp. aff. R. ? magnus Bukry. Sample 364-22, CC.

$11 \mathrm{a}, 12 \mathrm{a}$. Transmitted light.

$11 \mathrm{~b}, 12 \mathrm{~b}$. Phase contrast $(\times 2800)$.

Figure 13 Microchabdulus stradneri Bramlette and Martini.Crosspolarized light (X2800). Sample 364-14-1, $95-96 \mathrm{~cm}$.

(see p. 634) 


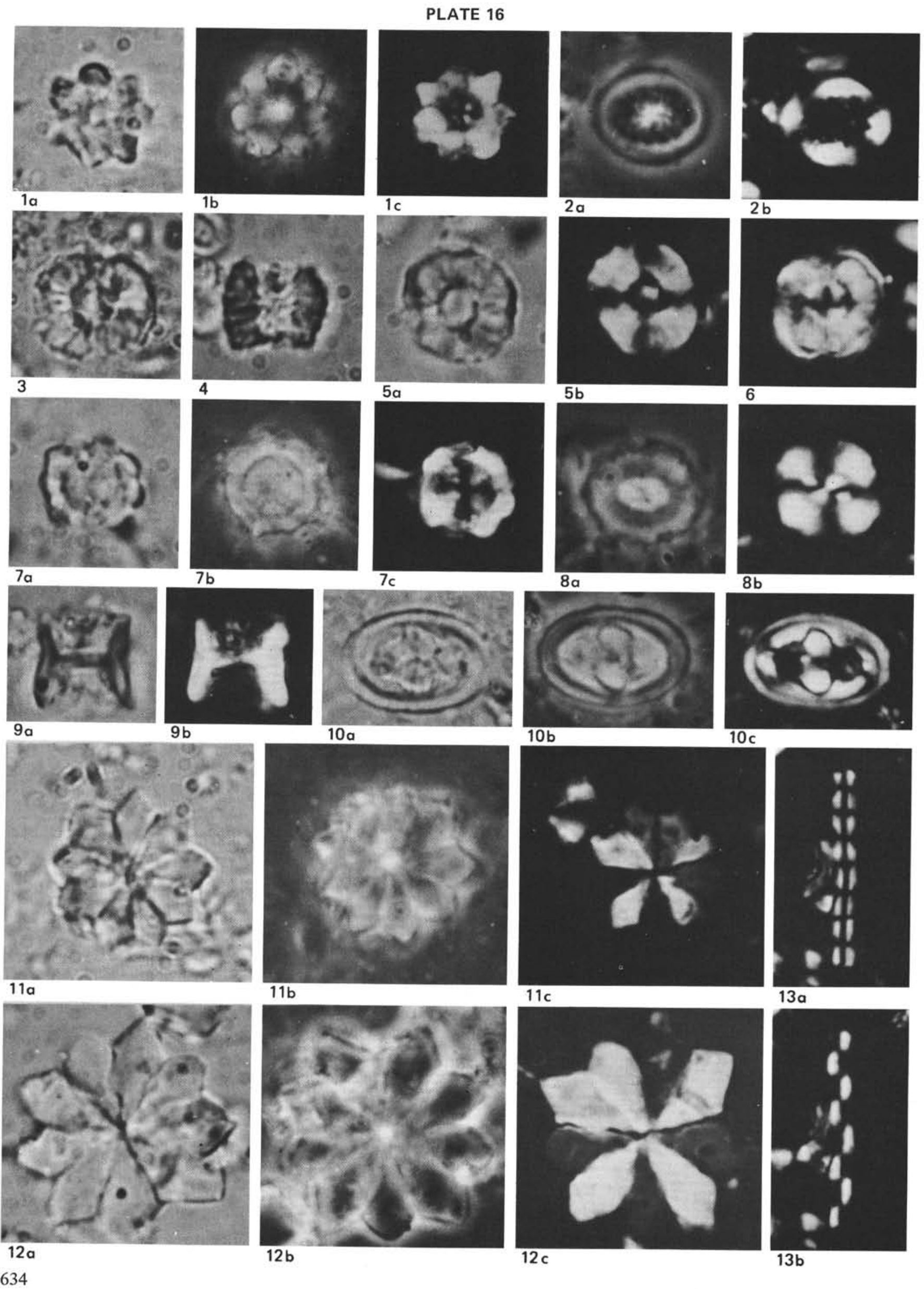

